\title{
Sea-Floor Tectonics and Submarine Hydrothermal Systems
}

\author{
Mark D. Hannington, ${ }^{\dagger}$ \\ Department of Earth Sciences, University of Ottawa, Canada K1N 6N5 \\ Cornel E. J. DE Ronde, \\ Institute of Geological and Nuclear Sciences, P.O. Box 31-312, Lower Hutt, New Zealand \\ and Sven Petersen \\ Leibniz-Institut für Meereswissenschaften, IFM-GEOMAR, D-24148 Kiel, Germany
}

\begin{abstract}
The discovery of metal-depositing hot springs on the sea floor, and especially their link to chemosynthetic life, was among the most compelling and significant scientific advances of the twentieth century. More than 300 sites of hydrothermal activity and sea-floor mineralization are known on the ocean floor. About 100 of these are sites of high-temperature venting and polymetallic sulfide deposits. They occur at mid-ocean ridges $(65 \%)$, in back-arc basins $(22 \%)$, and on submarine volcanic arcs $(12 \%)$. Although high-temperature, $350^{\circ} \mathrm{C}$, black smoker vents are the most recognizable features of sea-floor hydrothermal activity, a wide range of different styles of mineralization has been found. Different volcanic substrates, including mid-ocean ridge basalt, ultramafic intrusive rocks, and more evolved volcanic suites in both oceanic and continental crust, as well as temperature-dependent solubility controls, account for the main geochemical associations found in the deposits. Although end-member hydrothermal fluids mainly originate in the deep volcanic basement, the presence of sediments and other substrates can have a large effect on the compositions of the vent fluids. In arc and backarc settings, vent fluid compositions are broadly similar to those at mid-ocean ridges, but the arc magmas also supply a number of components to the hydrothermal fluids.

The majority of known black smoker vents occur on fast-spreading mid-ocean ridges, but the largest massive sulfide deposits are located at intermediate- and slow-spreading centers, at ridge-axis volcanoes, in deep backarc basins, and in sedimented rifts adjacent to continental margins. The range of deposit sizes in these settings is similar to that of ancient volcanic-associated massive sulfide (VMS) deposits. Detailed mapping, and in some cases drilling, indicates that a number of deposits contain 1 to 5 million tons (Mt) of massive sulfide (e.g., TAG hydrothermal field on the Mid-Atlantic Ridge, deposits of the Galapagos Rift, and at $13^{\circ} \mathrm{N}$ on the East Pacific Rise). Two sediment-hosted deposits, at Middle Valley on the Juan de Fuca Ridge and in the Atlantis II Deep of the Red Sea, are much larger (up to 15 and $90 \mathrm{Mt}$, respectively).

In the western Pacific, high-temperature hydrothermal systems occur mainly at intraoceanic back-arc spreading centers (e.g., Lau basin, North Fiji basin, Mariana trough) and in arc-related rifts at continental margins (e.g., Okinawa trough). In contrast to the mid-ocean ridges, convergent margin settings are characterized by a range of different crustal thicknesses and compositions, variable heat flow regimes, and diverse magma types. These variations result in major differences in the compositions and isotopic systematics of the hydrothermal fluids and the mineralogy and bulk compositions of the associated mineral deposits. Intraoceanic back-arc basin spreading centers host black smoker vents that, for the most part, are very similar to those on the mid-ocean ridges. However, isotopic data from both the volcanic rocks and the sulfide deposits highlight the importance of subduction recycling in the origin of the magmas and hydrothermal fluids. Back-arc rifts in continental margin settings are typically sediment-filled basins, which derive their sediment load from the adjacent continental shelf. This has an insulating effect that enhances the high heat flow associated with rifting of the continental crust and also helps to preserve the contained sulfide deposits. Large hydrothermal systems have developed where initial rifting of continental crust or locally thickened arc crust has formed large calderalike sea-floor depressions, similar to those that contained major VMS-forming systems in the geologic record. Hydrothermal vents also occur in the summit calderas of submarine volcanoes at the volcanic fronts of arcs. However, this contrasts with the interpreted settings of most ancient VMS deposits, which are considered to have formed mainly during arc rifting. Hydrothermal vents associated with arc volcanoes show clear evidence of the direct input of magmatic volatiles, similar to magmatic-hydrothermal systems in subaerial volcanic arcs. Several compelling examples of submarine epithermal-style mineralization, including gold-base metal veins, have been found on submarine arc volcanoes, and this type of mineralization may be more common than is presently recognized.

Mapping and sampling of the sea floor has dramatically improved geodynamic models of different submarine volcanic and tectonic settings and has helped to establish a framework for the characterization of many similar ancient terranes. Deposits forming at convergent margins are considered to be the closest analogs of ancient VMS. However, black smokers on the mid-ocean ridges continue to provide critically important information about metal transport and deposition in sea-floor hydrothermal systems of all types. Ongoing sea-floor exploration in other settings is providing clues to the diversity of mineral deposit types that occur in different environments and the conditions that are favorable for their formation.
\end{abstract}




\section{Introduction}

SEA-FLOOR hydrothermal venting is one of the oldest and most important ore-forming processes on Earth and has produced some of the largest and most valuable ore deposits mined to date. Volcanic-associated and sedimentary-exhalative massive sulfide deposits have accounted for more than half of the past global production of zinc and lead, 7 percent of the copper, 18 percent of the silver, and a significant amount of gold and other byproduct metals (Singer, 1995). These include some of the oldest ore deposits in the geologic record (e.g., 3.45 billion year-old massive sulfide deposits in the Pilbara of Western Australia and the Barberton and Murchison greenstone belts of South Africa: de Ronde et al., 1994; Van Kranendonk et al., 2002). Franklin et al. (1981), in their landmark paper on volcanic-associated massive sulfide deposits (VMS), pointed out that almost every major tectonic setting with submarine volcanic rocks has the potential to host massive sulfide deposits. Comparisons with younger deposits in well-preserved terranes (e.g., Kuroko-, Cyprus-, and Besshi-type, named after their type localities) have been the basis for interpreting the settings of many ancient VMS. However, attempts to correlate ancient deposit types with tectonic setting have been limited by the generally broad distinctions made between arc, back-arc, and mid-ocean ridge environments in the geologic record and by the fact that deposits with different host-rock associations commonly occur in the same regions or districts. Much of the uncertainty in assigning deposits to specific tectonic settings has arisen from the lack of detailed information about the structure, volcanic architecture, and lithogeochemistry of the different sea-floor environments. In the last 25 years, mapping of the sea floor has allowed more precise geodynamic models of the plate margins, and sampling of the volcanic rocks has helped to establish a petrogenetic framework for the tectonic classification of similar ancient terranes (e.g., Kerrich and Wyman, 1997). Franklin et al. (2005) apply many of these findings in their most recent review and classification of the major VMS districts worldwide.

When they were first discovered on the mid-ocean ridges, black smokers were considered probable modern analogs of ophiolite-hosted massive sulfide deposits, such as those in Cyprus and Oman. Although there are remarkable similarities between the deposits (e.g., Hannington et al., 1998; Galley and Koski, 1999), it has long been recognized that most ophiolites are not representative of mid-ocean ridge crust but are mostly fragments of extensional back-arc basins formed in suprasubduction settings. The discovery of black smokers in back-arc spreading centers of the western Pacific has since confirmed that this was a more likely setting for many ancient VMS. More than 80 percent of VMS deposits are thought to have formed in arc-related rifts. Almost half of the global VMS tonnage preserved in the geologic record was generated during a brief 340 m.y. period of subduction and associated arc and back-arc volcanism along the Paleozoic continental margins of the Appalachians, the North American Cordillera, the Tasman Geosyncline, the Iberian Pyrite Belt, and the Southern Urals (Barrie and Hannington, 1999; Franklin et al., 2005). A commonly accepted model for the tectonic setting of many of these deposits is that of an aborted arc rift, similar to that proposed for the Miocene Kuroko deposits (Cathles et al., 1983). The major VMS-hosting districts in many of these regions share a common stratigraphic succession, beginning with arc-related submarine volcanism, followed by rapid extension and subsidence to deep marine conditions, and then a return to compression with closure and uplift of the basins and renewed arc volcanism. Such rapid changes in stress regimes, from compressional to tensional and back to compressional, are typical of complex microplate mosaics along the convergent margins of the present-day western Pacific.

In this paper, we examine the different submarine environments that host active sea-floor hydrothermal systems in today's oceans and discuss the links between geodynamic settings, the compositions of the mineral deposits, and the origins of their respective hydrothermal fluids. At the time of writing, more than 300 sites of sea-floor hydrothermal activity and related mineral deposits have been found in the oceans. About 100 are sites of high-temperature $\left(350^{\circ} \mathrm{C}\right)$ venting or polymetallic sulfide mineralization (Fig. 1, App. Table A1). The history of their exploration since the discovery of the first black smokers on the East Pacific Rise in 1979 (Francheteau et al., 1979; Hekinian et al., 1980; Spiess et al., 1980) can be followed in reviews by Rona et al. (1983), Rona (1984, 1988), Rona and Scott (1993), and Ishibashi and Urabe (1995).

\section{Tectonic Settings, Classification, and Distribution of Hydrothermal Vents}

The extent of the modern oceans, which cover 71 percent of the Earth's surface, was reached in the Middle Proterozoic, when cratonization attained its near present-day steady state. However, the crust of the ocean floor is no older than 180 m.y. This means that nearly two-thirds of the planet has been completely resurfaced by sea-floor spreading and subduction since the Cretaceous. As a result, submarine volcanic rocks are the most widespread and abundant surficial igneous products on Earth (Batiza and White, 2000). More than 80 percent of the world's active volcanoes occur in the oceans, and the vast majority of surficial hydrothermal activity is concentrated along the $55,000 \mathrm{~km}$ of mid-ocean ridges and 22,000 $\mathrm{km}$ of island arcs (Lowell, 1991; Sigurdsson, 2000). Almost all sea-floor hydrothermal activity occurs at the plate margins, where a strong spatial and temporal correlation exists between magmatism, seismicity, and high-temperature venting. The majority of the known vents are located along the midocean ridges $(65 \%)$, with the remainder in back-arc basins (22\%), along volcanic arcs (12\%), and on intraplate volcanoes (1\%: Baker and German, 2004; Hannington et al., 2004). The lack of known vents in some parts of the oceans (e.g., the polar regions and Southern Ocean) mainly reflects the difficulties of marine research at these latitudes. Recent discoveries of hydrothermal plumes and massive sulfide deposits in the high Arctic (e.g., Michael et al., 2003) and in Antarctica (e.g., Klinkhammer et al., 2001) confirm that sea-floor hydrothermal activity in remote parts of the oceans is little different from that observed elsewhere. Despite their abundance, black smoker deposits that formed on mid-ocean ridges are poorly represented in the geologic record, owing to subduction of the ridges. However, the volcanic, tectonic, and hydrothermal processes observed at ridge crests form the basis for models of ore-forming systems in many other settings. 


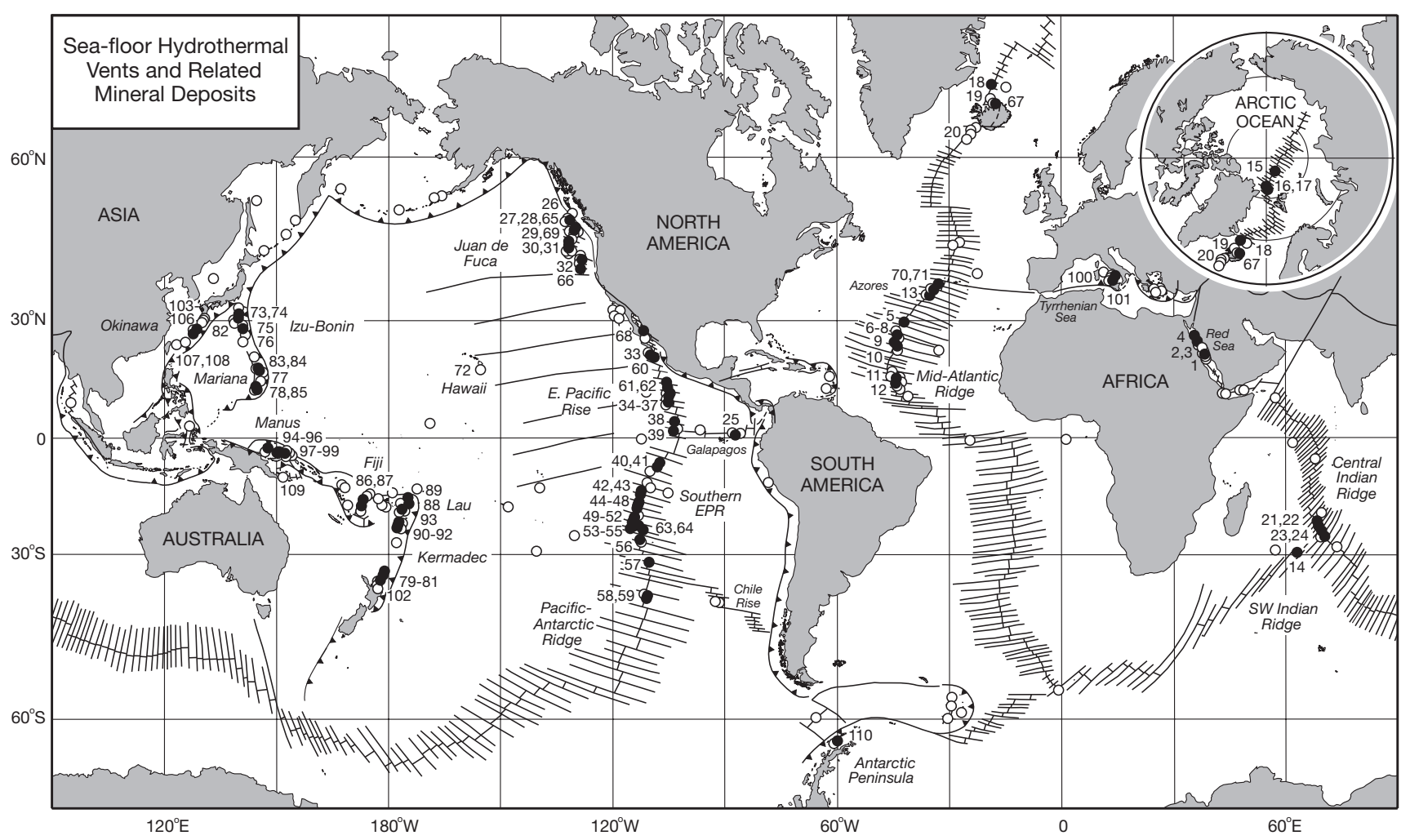

Intracontinental rifts

1. Atlantis II Deep, Red Sea

2. Thetis, Nereus, Gypsum Deeps

3. Kebrit Deep, Red Sea

4. Shaban Deep, Red Sea

Slow-spreading mid-ocean ridges

5. Broken Spur, Mid-Atlantic Ridge

6. TAG Mound, Mid-Atlantic Ridge

MIR Zone, Mid-Atlantic Ridge

Alvin Zone, Mid-Atlantic Ridge

$24^{\circ} 30^{\prime} \mathrm{N}$, Mid-Atlantic Ridge

10. Snakepit Field, Mid-Atlantic Ridge

11. $15^{\circ} \mathrm{N}$, Mid-Atlantic Ridge

12. Logatchev Field, Mid-Atlantic Ridge

13. Rainbow Field, Mid-Atlantic Ridge

14. Mt. Jourdanne, Southwest Indian Ridge

15. Gakkel Ridge, Arctic Ocean

16. Aurora Field, Arctic Ocean

17. Lena Trough, N. Mid-Atlantic Ridge

18. N. Kolbeinsey Ridge

19. Kolbeinsey Ridge

20. Reykjanes Ridge

Intermediate-rate mid-ocean ridges

21. JX/MESO Zone, Central Indian Ridge

22. EX/FX Zone, Central Indian Ridge

23. Kairei Field, Central Indian Ridge

24. Edmond Field, Central Indian Ridge

25. Galapagos Rift

26. S. Explorer Ridge

27. High-Rise, Endeavour Ridge

28. Main Field, Endeavour Ridge

29. CoAxial Site, Juan de Fuca Ridge

30. North Cleft, Juan de Fuca Ridge

31. South Cleft, Juan de Fuca Ridge

32. North Gorda Ridge

Fast-spreading mid-ocean ridges

33. $21^{\circ} \mathrm{N}$, Northern EPR

34. $12^{\circ} 50^{\prime} \mathrm{N}$, Northern EPR

35. $11^{\circ} 32$ ' N, EPR Seamount

36. $11^{\circ} \mathrm{N}$, Northern EPR

37. $9-10^{\circ} \mathrm{N}$, Northern EPR
38. $3^{\circ} 55^{\prime} \mathrm{N}$, Northern EPR

39. $1^{\circ} 44^{\prime} \mathrm{N}$, AHA Field, EPR

40. $7^{\circ} 00^{\prime} \mathrm{S}$, Southern EPR

41. $7^{\circ} 30^{\prime} \mathrm{S}$, Southern EPR

42. $14^{\circ} 00^{\prime} S$, Southern EPR

43. $15^{\circ} 00^{\prime} \mathrm{S}$, Southern EPR

44. $16^{\circ} 40^{\prime} \mathrm{S}$, Southern EPR

45. $17^{\circ} 27^{\prime} \mathrm{S}$, Southern EPR

46. $17^{\circ} 30^{\prime} \mathrm{S}$, Southern EPR

47. $18^{\circ} 10^{\prime} \mathrm{S}$, Southern EPR

48. $18^{\circ} 26^{\prime} \mathrm{S}$, Southern EPR

49. $20^{\circ} 00^{\prime} \mathrm{S}$, Southern EPR

50. $20^{\circ} 50 ' \mathrm{~S}$, Southern EPR

51. $21^{\circ} 30$ 'S, Southern EPR

52. $21^{\circ} 50^{\prime} S$, Southern EPR

53. $22^{\circ} 30^{\prime} \mathrm{S}$, Southern EPR

54. $22^{\circ} 58$ 'S, Southern EPR

55. $23^{\circ} 30^{\prime} \mathrm{S}$, Southern EPR

56. $26^{\circ} 10^{\prime} \mathrm{S}$, Southern EPR

$57 \quad 31^{\circ} 51^{\prime} \mathrm{S}$, Southern EPR

58. $37^{\circ} 40^{\prime} \mathrm{S}$, Pacific-Antarctic Ridge

59. $37^{\circ} 48^{\prime} \mathrm{S}$, Pacific-Antarctic Ridge

Off-axis volcanoes

60. Green Seamount

61. $14^{\circ} \mathrm{N}$, Northern EPR

62. $13^{\circ} \mathrm{N}$, Northern EPR

63. $23^{\circ} 19^{\prime} \mathrm{S}$, Southern EPR

64. Pito Seamount

Sedimented ridges and related rifts

65. Middle Valley

66. Escanaba Trough

67. Grimsey Field

68. Guaymas Basin

Ridge-hotspot intersections

69. Axial Seamount, Juan de Fuca Ridge

70. Lucky Strike, Azores

71. Menez Gwen, Azores

Intraplate volcano

72. Loihi Seamount, Hawaii

Intraoceanic arcs

73. Kita Bayonnaise, Izu-Bonin Arc
74. Myonjinsho, Izu-Bonin Arc

75. Suiyo Seamount, Izu-Bonin Arc

76. Kaikata Seamount, Izu-Bonin Arc

77. East Diamante, Mariana Arc

78. Forecast Field, Mariana Arc

79. Clark Seamount, Kermadec Arc

80. Rumble II West, Kermadec Arc

81. Brothers, Kermadec Arc

Intraoceanic back-arc basins

82 Sumisu Rift, Izu-Bonin Arc

83. Alice Springs, Mariana Trough

84. Central Mariana Trough

85. Southern Mariana Trough

86. White Lady, North Fiji Basin

87. Père Lachaise, North Fiji Basin

88. Papatua Site, Northern Lau Basin

89. Kings Triple Junction, Northern Lau

90. White Church, Southern Lau Basin

91. Vai Lili Field, Southern Lau Basin

92. Hine Hina, Southern Lau Basin

93. Central Lau Basin

94. Central Manus Basin

95. Vienna Woods, Manus Basin

96. Western Ridge, Manus Basin

Transitional island arcs and back-arc rifts

97. Pacmanus, E. Manus Basin

98. SuSu Knolls, E. Manus Basin

99. Desmos Cauldron, E. Manus Basin

100. Palinuro Seamount, Tyrrhenian Sea

101. Panarea Seamount, Tyrrhenian Sea

102. Calypso Vents, Taupo Zone

Intracontinental back-arc rifts

103. Minami-Ensei, Okinawa Trough

104. North Iheya, Okinawa Trough

105. Clam Site, Okinawa Trough

106. Izena Cauldron, Okinawa Trough

107. Hatoma Knoll, S. Okinawa Trough

108. Yonaguni Knoll, S. Okinawa Trough Volcanic rifted margins

109. Franklin Seamount, Woodlark Basin

110. Bransfield Strait, Antarctica

FIG. 1. Distribution of sea-floor hydrothermal vents and related mineral deposits. Numbers refer to high-temperature hydrothermal vents and related polymetallic sulfide deposits (closed circles) listed in Table A1. Other hydrothermal deposits and low-temperature vent sites, including Fe-Mn crusts and metalliferous sediments, are indicated by open circles (see Hannington et al., 1994, 2004, for details). Major spreading ridges and subduction zones are indicated. 


\section{Mid-ocean ridges}

The mid-ocean ridges account for 62 percent of the global magmatic budget (both intrusive and extrusive) and 73 percent of surficial volcanic activity (Perfit and Davidson, 2000). The amount of new oceanic crust formed at the ridges is on the order of $18 \mathrm{~km}^{3} / \mathrm{yr}$ (Sigurdsson, 2000). The different types of ridges are discriminated on the basis of spreading rate and morphology, which vary in response to regional tectonic stresses and rates of magma supply. Fast-spreading ridges (full spreading rates of $6-10 \mathrm{~cm} / \mathrm{yr}$ ) occur in relatively thin oceanic crust and are characterized by abundant volcanic eruptions; intermediate-rate $(4-6 \mathrm{~cm} / \mathrm{yr})$ and slow-spreading (1-4 cm/yr) ridges occur in relatively thick crust and are characterized by only intermittent volcanism between long periods of essentially amagmatic, tectonic extension and/or intrusive activity. The fast-spreading ridges account for about 25 percent of the total length of the ridges, whereas 15 percent of the ridges are classified as intermediate-rate and 60 percent are slow-spreading (Table A1). Superfast-spreading centers, such as the southern East Pacific Rise (up to $17 \mathrm{~cm} / \mathrm{yr}$ ), and ultraslow-spreading centers, such as the Arctic and Southwest Indian Ridges $(<1 \mathrm{~cm} / \mathrm{yr})$, also have been identified (Urabe et al., 1995; Dick et al., 2003). At fast- and intermediate-rate spreading centers, melt lenses occur at depths of 1 to $4 \mathrm{~km}$ and are typically several kilometers in length, 1 $\mathrm{km}$ wide, and $100 \mathrm{~m}$ thick, with the shallowest magma occurring beneath the fastest-spreading ridges (Fornari and Embley, 1995; Perfit and Chadwick, 1998). The lower density of the hot lithosphere along the ridges contributes to a regional bathymetric minimum at the ridge axis. At fast-spreading ridges melt also is extruded onto the sea floor faster than the rate of extension, so the lava flows accumulate as local volcanic highs up to $100 \mathrm{~m}$ above the surrounding sea floor. The eruptive fissures typically occupy a narrow axial graben $(1 \mathrm{~km}$ wide), and this is the most common location for hydrothermal vents.

The rate of magma supply, the depth of the subaxial magma, and the extent of magmatic versus tectonic extension influence the size and vigor of hydrothermal convection cells on the ridges, and there is a general correlation between the spreading rate and the incidence of hydrothermal venting (Baker et al., 1996). At fast-spreading centers, high-temperature fluids circulate to relatively shallow depths (1-2 km), owing to the shallow subaxial magma. At intermediate-rate spreading centers, and especially at slow-spreading ridges, deeply penetrating faults allow circulation of hydrothermal seawater locally to much greater depths $(5-8 \mathrm{~km}$ : Rona et al., 1987; Manning et al., 2000). These differences are partly responsible for the longevity of the hydrothermal systems and the large size of many of the deposits on slow- to intermediate-rate spreading ridges (German and Parson, 1998). Ridges are also segmented at scales of $10 \mathrm{~s}$ to $100 \mathrm{~s}$ of $\mathrm{km}$ by a variety of discontinuities, including transform faults, overlapping spreading centers, and other nontransform offsets that affect the distribution of magmatic heat and convective hydrothermal circulation (Macdonald, 1998). At the scale of major ridge segments, high-temperature venting mainly occurs along the shallowest portions of the ridge, whereas the ends of segments are typically starved of magma and heat. The largest hydrothermal systems occur where volcanic eruptions are episodic and alternate with long periods of intense tectonic activity.

The extent of hydrothermal circulation at mid-ocean ridges is immense. A variety of geophysical measurements indicate that about 3 to $6 \times 10^{13} \mathrm{~kg} / \mathrm{yr}$ of seawater must be circulated through the axial zones of the world's mid-ocean ridges and heated to a temperature of at least $350^{\circ} \mathrm{C}$ to remove the heat from newly formed crust (Elderfield and Schultz, 1996). Other estimates based on geochemical mass balances have ranged as high as $1.5 \times 10^{14} \mathrm{~kg} / \mathrm{yr}$ (Baker et al., 1995; Kadko et al., 1995). However, most of the fluids passing through the axis of the ridges have temperatures much lower than $350^{\circ} \mathrm{C}$, implying that a much larger combined flux of low- and hightemperature fluids is required to account for the convective heat loss. This combined flux $\left(>10^{14} \mathrm{~kg} / \mathrm{yr}\right)$ is sufficient to cycle the entire mass of the world's oceans $\left(1.37 \times 10^{21} \mathrm{~kg}\right)$ through the axis of the mid-ocean ridges every 5 to 10 m.y. (Stein and Stein, 1994; Elderfield and Schultz, 1996). If convective heat flux from the flanks of the ridges is included in this calculation (crust older than $1 \mathrm{Ma}$ but $<65 \mathrm{Ma}$ ), the cycling time for the world's oceans through the ridges is less than 1 m.y. From rates of crustal cooling, the magnitude of convective heat loss at the ridge axis is estimated to be $1.8 \pm$ $0.3 \times 10^{12} \mathrm{~W}$ (Mottl, 2003). However, less than 10 percent of this heat is discharged at black smoker temperatures because of mixing and cooling of the fluids on their way to the sea floor (Schultz et al., 1992; Baker et al., 1993). Assuming a heat flux of 2 to $5 \mathrm{MW}$ for a single black smoker vent (e.g., discharge rates of 1-2 kg/s: Converse et al., 1984; Bemis et al., 1993), the estimated flux of high-temperature fluids to the sea floor $\left(10 \%\right.$ of $\left.1.8 \pm 0.3 \times 10^{12} \mathrm{~W}\right)$ would be equivalent to about 50,000 to 100,000 black smokers (i.e., at least one black smoker for every $1 \mathrm{~km}$ of ridge). However, the number of known black smokers is extremely small by comparison, and their distribution is far from uniform. For example, a single large vent field may contain as many as 100 black smoker vents having a total heat output of 200 to 500 MW (e.g., Becker and Von Herzen, 1996). Thus, one large vent field every 50 to $100 \mathrm{~km}$ (i.e., between 500 and 1,000 vent fields) would account for the estimated high-temperature discharge at mid-ocean ridges.

Most mid-ocean ridge vents occur at water depths of between 2,000 and 3,000 m (Fig. 2, Table A1). The deepest vents mostly occur on slow- or ultraslow-spreading centers that lack the crustal buoyancy associated with large volumes of subaxial magma. At the average depth of the mid-ocean ridges $(2,600 \mathrm{~m})$, typical $350^{\circ} \mathrm{C}$ vent fluids are below the boiling temperature of seawater $\left(390^{\circ} \mathrm{C}\right.$ at $\left.260 \mathrm{bars}\right)$. At shallower depths, the near-vertical adiabats of black smoker fluids may intersect the two-phase boundary for seawater, and the fluids will boil (Fig. 3). The temperatures of the vents at the sea floor will then be limited by cooling of the fluids as they rise along the two-phase curve. Although massive sulfides have been found at water depths as shallow as a few hundred meters, there are important physical limitations to the depth at which high-temperature venting can occur if the pressure at the sea floor is insufficient to prevent boiling (Ohmoto, 1996).

Fast-spreading ridges: The type example of a fast-spreading ridge is the East Pacific Rise (EPR), where about half of the 


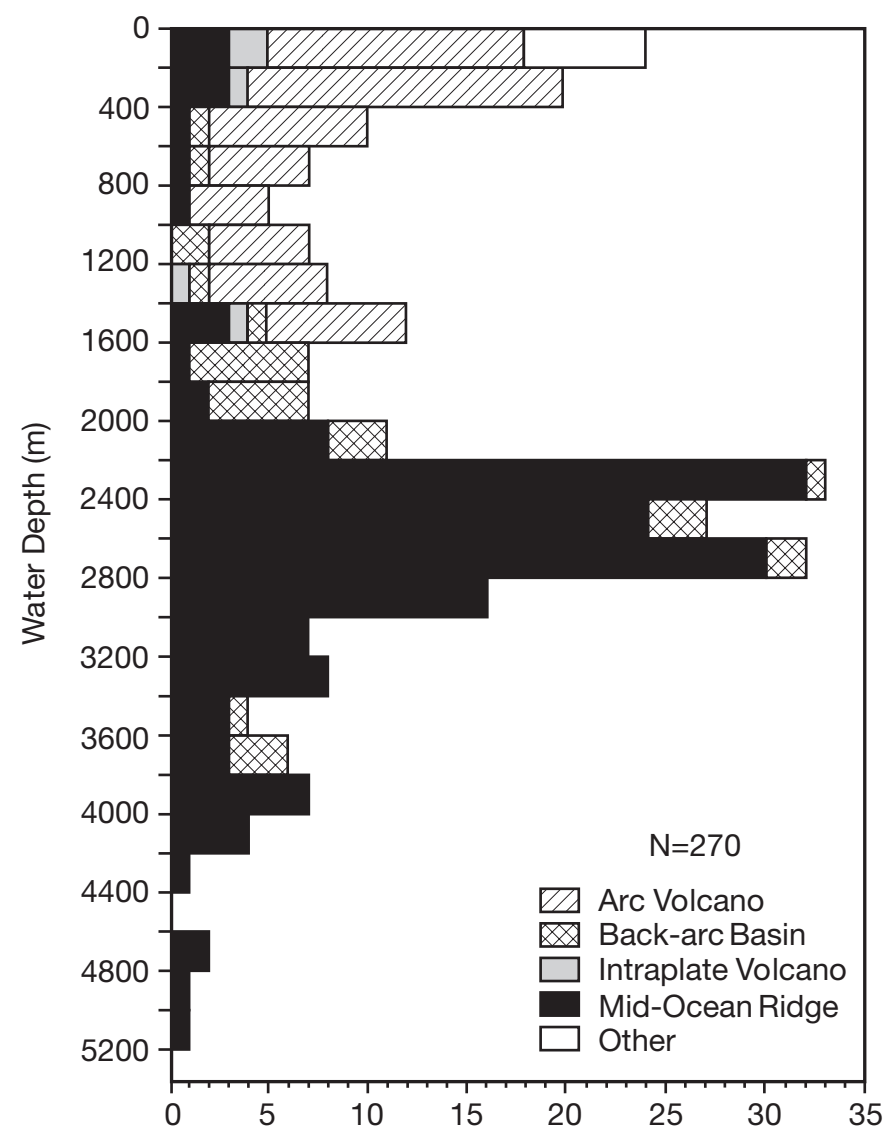

FIG. 2. Depth distribution of sea-floor hydrothermal vents in different volcanic and tectonic settings (modified after Massoth et al., 2003, with additional data from Hannington et al., 2004). The tectonic classifications refer to Figure 1 and Table A1. Other vents include mainly low-temperature, shallow-water hot springs in coastal environments and offshore extensions of subaerial geothermal systems. The distribution of vents partly reflects the limits of exploration but is consistent with the known depth ranges of the different tectonic settings indicated.

known black smoker vents occur. The East Pacific Rise extends for 7,000 km from the Gulf of California to the PacificAntarctic Ridge in the Southern Ocean. Venting correlates closely with the areas of most recent volcanic eruptions (e.g., $9^{\circ} \mathrm{N}$ and $17^{\circ} \mathrm{S}$ EPR, $37^{\circ} \mathrm{S}$ Pacific-Antarctic Ridge). At $9^{\circ} \mathrm{N}$, the subaxial magma is only 1.4 to $1.6 \mathrm{~km}$ below the sea floor (Vera and Diebold, 1994), and eruption rates are very high. The first well-documented eruption at a hydrothermal vent site was observed here in 1991, and eruptions are thought to occur at intervals of 10 s of years in cycles lasting 100 to 1,000 years (Haymon et al., 1991, 1993). Such frequent eruptions can disrupt the flow of hydrothermal fluids and bury sulfide deposits that are localized along the eruptive fissure. As a result, the vent complexes at fast-spreading ridges tend to be small (less than a few thousand tons) and the deposits are rapidly displaced from their heat source by the high spreading rates.

Intermediate-rate spreading centers: Intermediate-rate spreading centers are characterized by lower rates of magma supply, deeper axial valleys, and greater structural control on hydrothermal upflow than at fast-spreading ridges. The beststudied examples are the Juan de Fuca and Gorda Ridge

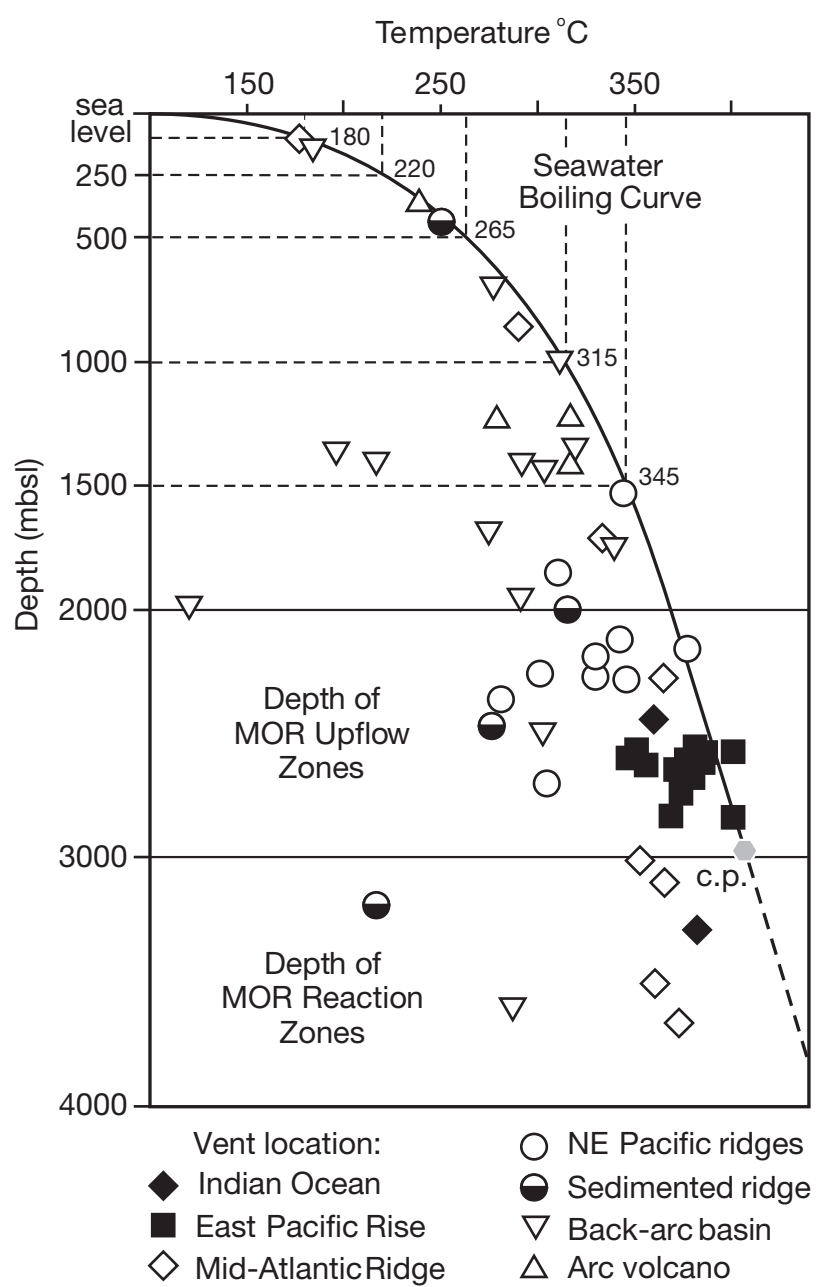

FIG. 3. Two-phase curve for seawater after Bischoff and Rosenbauer (1987), including the critical point of seawater (c.p. $=407^{\circ} \mathrm{C}, 298$ bars; Bischoff and Rosenbauer, 1984), and the maximum vent temperatures for hydrothermal systems in different volcanic and tectonic settings (from Table A1). The depth (pressure) ranges for the high-temperature reaction zones and hydrothermal upflow zones at mid-ocean ridges are approximate only (see text for discussion). Temperature-depth relationships on the two-phase curve for seawater indicate that shallow-water hydrothermal systems are necessarily limited to relatively low temperatures (e.g., $<265^{\circ} \mathrm{C}$ at water depths of less than $500 \mathrm{~m}$ ). This is an important control on the composition of hydrothermal precipitates forming at the sea floor.

system (900 km in length) and the Galapagos Rift (1,700 km in length), which include some of the largest known vent fields. Depths to the subaxial magma are 2.5 to $3.5 \mathrm{~km}$ (Perfit et al., 1999), and eruptions typically occur only at 100-yr intervals (Embley et al., 2000). Whereas most mid-ocean ridges are dominated by normal incompatible element-depleted mid-ocean ridge basalt (N-MORB), some intermediate-rate spreading centers have more evolved magma compositions (ferrobasalt and andesite). This may be related to magma mixing, fractional crystallization of magma at shallow to intermediate crustal depths, or local assimilation of hydrated crust (Perfit et al., 1999). Enriched basalt (E-MORB) is common along parts of the Juan de Fuca Ridge system (e.g., Sours-Page et al., 1999), and the high concentrations of incompatible trace elements in such lavas (e.g., Ba, Cs, Rb, 
Th, U, K, and LREE) are clearly reflected as enrichments of these elements in the hydrothermal fluids and the deposits at these locations (Fig. 4, App. Table A2).

Hydrothermal venting on intermediate-rate spreading ridges is commonly focused along the walls of the rift valley as well as in the axial fissure zones. Because of large buoyancy forces acting on the hydrothermal fluids, it is not uncommon for high-temperature venting to occur on top of local structural highs (e.g., on high fault scarps or horsts). On the Endeavour segment of the Juan de Fuca Ridge, which is one of the most hydrothermally active intermediate-rate spreading centers, 100 to 150 black smokers occur in six vent fields along a 15-km segment of the axial valley (Delaney et al., 1992; Kelley et al., 2001a). The main vent complexes are evenly spaced, 2 to $3 \mathrm{~km}$ apart, and seismic evidence confirms that the high-temperature fluids are sourced at depths of at least 2 to $3 \mathrm{~km}$ (Wilcock et al., 2002).

Slow-spreading ridges: Slow-spreading ridges have a low melt supply and experience only intermittent sea-floor eruptions. Here, the crust is composed mainly of gabbroic intrusions and lesser ultramafic rocks, and the ridge is characterized by a deep, fault-bounded axial valley up to $15 \mathrm{~km}$ wide and $2 \mathrm{~km}$ deep. Magma is delivered at multiple point sources, rather than at linear eruptive fissures, forming mainly pillow volcanoes (Smith et al., 1999). Only a few seismic studies have shown evidence of melt accumulation below slow-spreading ridges (Sinha et al., 1999; Madge et al., 2000), and eruptions are separated by tens of thousands of years (e.g., Karson, 2002; Kelley et al., 2002). However, individual pillow volcanoes (e.g., 50-100 $\mathrm{m}$ high and 1-10 km diam) may involve relatively large volumes of lava. As at intermediate-rate spreading centers, slow-spreading ridges commonly include both N-MORB and E-MORB compositions.

Until 1984, it was generally accepted that hydrothermal activity on slow-spreading ridges would be limited because of the lack of near sea-floor magmatic heat. However, following the discovery of the TAG hydrothermal field on the Mid-Atlantic Ridge (Rona et al., 1986), it became apparent that the slow-spreading ridges may host some of the largest hydrothermal systems on the sea floor. Spreading is slowest in the north Atlantic and Arctic Oceans (1.1-1.3 cm/yr), but hydrothermal activity and sea-floor mineralization still occur at a number of different sites (e.g., Lena trough and Knipovich Ridge, north of Iceland, and on the Gakkel Ridge between $81^{\circ} \mathrm{N}$ and $86^{\circ} \mathrm{N}$ ). Similar hydrothermal venting occurs on the slow-spreading Southwest Indian Ridge (e.g., near the Rodriguez Triple Junction, between $21^{\circ} \mathrm{S}$ and $26^{\circ} \mathrm{S}$ ).

On the Mid-Atlantic Ridge, hydrothermal venting occurs on the floor of the rift valley (MARK area, Broken Spur), adjacent to the major bounding faults (TAG mound and $24.5^{\circ} \mathrm{N}$ ), and high on the walls of the rift valley (MIR and Alvin zones of the TAG hydrothermal field: Rona et al., 1993a, b; Kraznov et al., 1995; Humphris and Tivey, 2000; Petersen et al., 2000). The locations of the main fields are controlled by crosscutting transfer faults. The more complex structure of slow-spreading ridges also locally exposes a number of different substrates, including serpentinized ultramafic rocks (see ridge-transform intersections). Although the magma is deep or entirely absent, long-lived hydrothermal systems have developed as a result of the penetration of seawater along
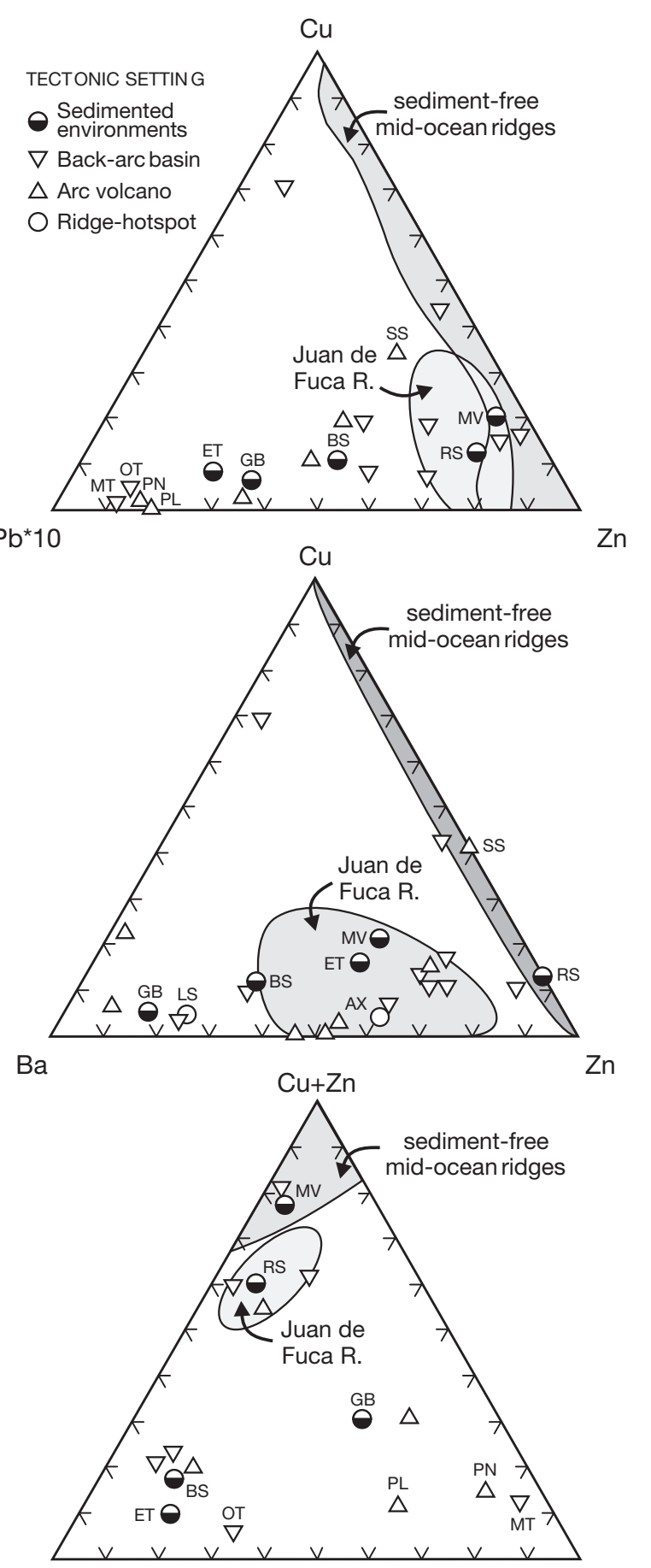

$(\mathrm{As}+\mathrm{Sb})^{*} 100$

$\mathrm{Pb}^{*} 10$

FIG. 4. $\mathrm{Cu}-\mathrm{Zn}-\mathrm{Pb}, \mathrm{Cu}-\mathrm{Zn}-\mathrm{Ba}$, and $(\mathrm{Cu}+\mathrm{Zn})-\mathrm{Pb}-(\mathrm{As}+\mathrm{Sb})$ ternary diagrams, showing the average bulk compositions of polymetallic sulfide deposits in different volcanic and tectonic settings (data are from Table A2 and Hannington et al., 2004). The field for sediment-free mid-ocean ridges includes all data from mid-ocean ridges (individual deposits not shown). The field for the Juan de Fuca Ridge encompasses deposits on the Juan de Fuca and adjoining Explorer Ridge systems (individual deposits not shown). Selected deposits are labeled as follows: AX = Axial Seamount, Juan de Fuca Ridge; $\mathrm{BS}=$ Bransfield Strait; ET $=$ Escanaba trough; $\mathrm{GB}=$ Guaymas basin; LS = Lucky Strike, Mid-Atlantic Ridge; MT = Mariana trough, Alice Springs; $\mathrm{MV}=$ Middle Valley; $\mathrm{OT}=$ Okinawa trough, $\mathrm{JADE}$ site $; \mathrm{PL}=$ Palinuro Seamount; PN = Panarea Seamount; RS = Atlantis II Deep, Red Sea; SS = Suiyo Seamount, Izu-Bonin arc. 
deeply penetrating structures into hot crystalline rock at great depths (e.g., Karson and Rona, 1990; Kleinrock and Humphris, 1996). Vent-fluid compositions in the TAG field differ slightly from those of black smokers on the fast-spreading ridges, in part because the hydrothermal system is older and larger, with a protracted history of subsea-floor alteration. Unexpectedly, some parts of the Mid-Atlantic Ridge system that are characterized by abundant magmatic activity, such as on the Reykjanes Ridge near Iceland, lack major submarine hydrothermal systems. This is partly because of the shallow water depths where the ridge crosses the Iceland plateau $(<500 \mathrm{~m})$ but also because of the lack of large-scale faulting that characterizes other parts of the Mid-Atlantic Ridge (German and Parson, 1998).

Off-axis volcanoes: Off-axis volcanoes account for a large proportion of the total magmatic budget of fast- and intermediate-rate spreading centers. The sizes of the volcanoes range from a few kilometers across to larger edifices up to 10s of kilometers in diameter and are most abundant within 5 to 10 $\mathrm{km}$ of the ridges. The off-axis volcanism is caused by hybrid magma plumbing systems at the distal edges of subaxial melt lenses or by abandoned magma bodies that have been spread off axis. The hybrid nature of the magma chambers is reflected in the variable chemistry of the erupted lavas (Perfit and Davidson, 2000). Some volcanoes are associated with nearby hot spots and form an obvious chain parallel to the direction of spreading. A few large sulfide deposits are known where the volcanoes are close to the ridge (e.g., at $13^{\circ} \mathrm{N}$ EPR). However, most off-axis volcanoes are characterized by only low-temperature, Fe-Mn oxide deposits. This likely reflects the small size of the associated magma bodies or the lack of deeply penetrating faults associated with the off-axis volcanism.

\section{Ridge-hot spot intersections}

Mantle plumes affect as much as 20 percent of the global mid-ocean ridge system (White, 1999), with spectacular results where the ridge migrates directly over a hot spot. Large, shield-type volcanoes, such as Axial Volcano on the Juan de Fuca Ridge $\left(>600 \mathrm{~km}^{3}\right)$, locally occur at these intersections. The enhanced magmatic activity is mainly a consequence of the thermal anomaly affecting the ridge, although there may be direct contributions from actively upwelling mantle material. Because of the large magma supply, eruption and drainout of significant volumes of melt can result in large sea-floor depressions on the ridge axis, and lava lakes are a common feature of these volcanoes (Embley et al., 1990; Fouquet et al., 1995). In some cases, a distinct volcano is not present, but the ridge axis lacks the usual morphology and is notably shallower than the rest of the ridge (e.g., near the Azores hot spot, where the Mid-Atlantic Ridge rises from a depth of 3,000 to only $900 \mathrm{~m}$ ). Large axial volcanoes are less common where fast-spreading ridges intersect a plume, although an enhanced magma supply and intense hydrothermal activity may coincide with the hot spot, as on the Pacific-Antarctic Ridge $\left(37^{\circ} \mathrm{S}\right.$ EPR) near the Foundation hot spot (Hekinian et al., 1999). The basaltic lavas at ridge-hot spot intersections are locally dominated by E-MORB and products of the fractionation of N-MORB. Notably silicic lavas, including andesite and dacite, have been sampled locally and are thought to be related to the thermal anomaly associated with the nearby mantle plume (Hekinian et al., 1999).

At Axial Volcano widespread high-temperature hydrothermal activity occurs along the walls of a large $3 \times 7-\mathrm{km}$ summit caldera and at eruptive fissures on the caldera floor (Embley et al., 1990). Similar hydrothermal activity occurs in the summit depressions of two large seamounts on the Mid-Atlantic Ridge near the Azores hot spot (Lucky Strike and Menez Gwen: Langmuir et al., 1997). Sulfide deposits at these locations are remarkably enriched in barite compared to normal mid-ocean ridge black smoker deposits, reflecting the shallower water depths and lower temperature of venting but also the higher Ba content of the enriched basalt. The shallower water depths promote boiling of the hydrothermal fluids, and volatiles also may be escaping from the shallow magma chambers, contributing to high gas contents in the vent fluids (e.g., Massoth et al., 1989; Butterfield et al., 1990).

\section{Ridge-transform intersections}

Large transform faults with offsets of $>30 \mathrm{~km}$ define the major ridge segments on intermediate- and slow-spreading ridges. The faults themselves are generally magma starved, although volcanism and low-temperature hydrothermal activity can occur at small pull aparts or relays within the transform zones. Near large faults, especially on slow-spreading ridges, vertical relief can be up to several kilometers, and this commonly exposes large sections of the underlying oceanic crust, including mafic and ultramafic intrusive rocks (e.g., Cannat et al., 1995; Lagabrielle et al., 1998; MacLeod et al., 2002). Similar exposures of abyssal peridotite have been documented near ridge-hot spot intersections (e.g., south of the Azores) and at ultraslow or highly oblique spreading segments in the north Atlantic (e.g., Gakkel Ridge) and on the Southwest Indian Ridge. Gabbro commonly intrudes the serpentinized peridotite after uplift and exposure (Auzende et al., 1994; Tucholke and Lin, 1994), and this drives high-temperature hydrothermal circulation in the ultramafic rocks (Kelley et al., 2002; Mevel, 2003). At several locations on the Mid-Atlantic Ridge, black smokers and massive sulfide deposits occur on top of the exposed mantle (Rainbow and Logatchev fields: Krasnov et al., 1995; Bogdanov et al., 1997, 2002). The presence of the ultramafic rocks in the substrate causes notable enrichments in $\mathrm{Ni}, \mathrm{Co}$, and platinum group elements (PGE) in the sulfide deposits (see below).

Fluids venting through faults in the ultramafic rocks have exceptionally high concentrations of $\mathrm{H}_{2}$ and $\mathrm{CH}_{4}$, which is thought to indicate ongoing serpentinization of peridotite at depth (e.g., Charlou et al., 1998, 2002; Früh-Green et al., 2004). At some locations, exothermic reactions associated with serpentinization of the ultramafic rocks are thought to be responsible for widespread low-temperature $\left(40^{\circ}-75^{\circ} \mathrm{C}\right)$ venting. Extensive deposits of carbonate and magnesium-hydroxide occur at the sea floor around these vents and in dense vein networks exposed in the faults (e.g., Lost City vent field: Kelley et al., 2001b; Früh-Green et al., 2003). The heat of serpentinization is capable of raising the rock temperature to about $260^{\circ} \mathrm{C}$, but the reactions also result in a 20 to 40 percent volume increase, so extensive veining is required to support fluid flow through the rocks. Some workers have suggested that a more likely source of heat for the 
low-temperature venting is the still hot lithosphere accessed by the deeply penetrating faults near the transforms (e.g., Allen and Seyfried, 2004).

\section{Intraplate volcanoes}

Intraplate hot-spot volcanoes account for about 12 percent of the Earth's magmatic budget (Schmidt and Schmincke, 2000), but almost no high-temperature hydrothermal venting is associated with these volcanoes, except in proximity to ridges, as noted above. Intraplate hot-spot volcanoes are produced by active ascent of deep mantle material in narrow magma conduits and, although large volumes of mantle-derived melt are delivered to the sea floor over time, the deep source of the melts and the narrow magma conduits appear to limit high-temperature hydrothermal venting at the sea floor. Sea-floor hydrothermal activity occurs only where there is evidence of near sea-floor magma (e.g., in summit calderas), and the hydrothermal precipitates consist mainly of $\mathrm{Fe}$ oxides, amorphous silica, and Fe-rich smectite (e.g., nontronite), commonly associated with filamentous bacterial mats. Numerous examples of such deposits have been documented on hot-spot volcanoes in the central Pacific (e.g., Stueben et al., 1992b; Hekinian et al., 1993; Stoffers et al., 1993; Staudigel et al., 2004). The highest temperature vents at an intraplate volcano (up to $200^{\circ} \mathrm{C}$ ) have been reported from the eruptive fissure at the summit of Loihi seamount, on the rifted southwest flank of Hawaii (Sedwick et al., 1992). Hydrothermal venting is commonly associated with extensive $\mathrm{CO}_{2}$ degassing, which locally causes notable low $\mathrm{pH}$ anomalies in the water column above the volcanoes (e.g., Cheminée et al., 1991). The low $\mathrm{pH}$ of the fluids may contribute to the dissolution of basalt glass, accounting for the unusually high concentrations of $\mathrm{Fe}$ in the fluids at low temperatures (Stueben et al., 1992b; Michard et al., 1993). The predominance of alkaline lavas (ocean island basalt, or OIB), the low temperatures of the vents $\left(<100^{\circ} \mathrm{C}\right)$, and the lack of vent-specific fauna are major differences between these sites and typical mid-ocean ridge vent fields (Schmidt and Schmincke, 2000).

\section{Sediment-covered ridges and related rifts}

About 5 percent of the world's active spreading centers are covered by sediment from nearby continental margins. The highest rates of burial are typically associated with clastic sedimentation from major rivers. Sedimentation rates in these settings can be on the order of 10 to $100 \mathrm{~cm} / 1,000 \mathrm{yr}$ (e.g., in the Gulf of California), compared to typical open ocean pelagic sedimentation of $1 \mathrm{~cm} / 1,000$ yr. During the Pleistocene low stand of sea level in the northeast Pacific, an abundant supply of terrigenous sediment buried several of the spreading centers of the Juan de Fuca and Gorda Ridges beneath 200 to $>1,000 \mathrm{~m}$ of turbidite. In the Escanaba trough, on the southern Gorda Ridge, most of the turbidite was deposited during a single glacial outburst and catastrophic flooding that originated in the Columbia River system (Normark and Reid, 2003).

Volcanic eruptions are rare at sedimented ridges, but subsea-floor intrusions are common (e.g., sill-sediment complexes: Einsele, 1985; Davis and Villinger, 1992). In Middle Valley, the Escanaba trough, and the Guaymas basin, hightemperature venting is focused around the margins of the buried sills, which are also partly responsible for driving hydrothermal circulation (Fisher and Becker, 1991; Zierenberg et al., 1993; Currie and Davis, 1994). However, high-temperature fluids mainly originate in the volcanic basement. Here, the upper few hundred meters of fractured basalt is several orders of magnitude more permeable than the overlying sediments and can accommodate large-scale fluid flow (e.g., Fisher et al., 2003). Fluids at the basalt-sediment contact reach greenschist temperatures (Davis and Fisher, 1994) and are intercepted along their flow path by basement highs and focused upward at growth faults or buried intrusions. Metals are deposited mainly below the sea floor by replacement of the host sediment. As a result, the sulfide deposits on sedimented ridges are typically larger than deposits on the bare mid-ocean ridges. The cap of sediment serves to retain heat, prevents the loss of metals to a hydrothermal plume, and protects the sulfide deposits from sea-floor weathering and oxidation. However, vents at the sea floor tend to have lower temperatures, lower concentrations of metals, and different proportions of the base metals (e.g., higher Pb: Fig. 4, Table A2).

In Middle Valley, uplifted blocks of sediment, $400 \mathrm{~m}$ in diameter and up to $50 \mathrm{~m}$ high, mark the location of the buried sills. The large Bent Hill sulfide deposit $(60 \times 90 \mathrm{~m})$ is situated $9 \mathrm{~km}$ from the axis of the valley, adjacent to one of the uplifted blocks. The first of several holes drilled at this site by the Ocean Drilling Program in 1992 penetrated 94 m of massive sulfide below the sea floor (Davis et al., 1992). A second mound of massive sulfide, $300 \mathrm{~m}$ away (ODP mound), is flanked by a hydrothermal vent with a maximum temperature of $264^{\circ} \mathrm{C}$. Active vents (up to $276^{\circ} \mathrm{C}$ ) also occur near the axis of Middle Valley, in an area of hard acoustic reflectors in the sediment (Ames et al., 1993; Goodfellow and Franklin, 1993). Drilling has confirmed that this hardened substrate is a zone of intense alteration above a sill-like body, $250 \mathrm{~m}$ below the sea floor (Davis et al., 1992).

Similar hydrothermal upflow occurs around several uplifted sediment hills in the Escanaba trough. The hills are 3 to $6 \mathrm{~km}$ in diameter and up to $120 \mathrm{~m}$ high, formed by the intrusion of dikes, sills, and laccoliths along the spreading axis (Zierenberg et al., 1994). The largest sulfide deposits $(270 \times$ $100 \mathrm{~m}$ ) occur adjacent to two of the hills in the northern Escabana trough, where vent temperatures reach a maximum of $217^{\circ} \mathrm{C}$ (Campbell et al., 1994). However, drilling indicates that massive sulfide formation is mainly restricted to the shallow sediments, 5 to $15 \mathrm{~m}$ deep (Zierenberg and Miller, 2000).

In the Gulf of California, large hydrothermal fields occur in several pull-apart basins formed by oblique segmentation of the northern East Pacific Rise where it intersects continental North America (Lonsdale, 1991). The Gulf is bounded by continental crust on both sides and therefore resembles an intracontinental rift (see below), but the individual basins are floored by oceanic crust. Narrow axial magnetic anomalies in the basins indicate the presence of intrusive magma at depth. The majority of the high-temperature venting occurs in the Guaymas basin, which comprises two pull-apart structures, 20 to $40 \mathrm{~km}$ long and 3 to $4 \mathrm{~km}$ wide. The sediment in these troughs is $500 \mathrm{~m}$ thick and is derived mainly from Tertiary volcanic rocks exposed on Sonoro, Mexico. Organic-rich sediment from the Rio Grande River also contributes to distinctive 
black mud in the basins, which contains 2 to 4 wt percent organic carbon (Curray et al., 1982). In the southern trough, three large buried sills, 1 to $2 \mathrm{~km}$ across, have pushed up sediment hills $100 \mathrm{~m}$ above the surrounding sea floor, similar to Middle Valley and the Escanaba trough (Lonsdale and Becker, 1985). Extensive hydrothermal venting $\left(315^{\circ} \mathrm{C}\right)$ and low-relief sulfide mounds occur around these features. Calcite, dolomite, manganiferous carbonate, and a variety of hydrocarbons are also locally abundant (Koski et al., 1985; Peter and Scott, 1991). The northern trough contains mainly ferromanganese crusts and talc deposits.

Similar hydrothermal deposits have been found in one of several heavily sedimented submarine valleys off the north coast of Iceland (Grimsey hydrothermal field: Hannington et al., 2001). The Grimsey field $(100 \times 300 \mathrm{~m})$ consists of mounds of anhydrite and talc with vent temperatures of $250^{\circ} \mathrm{C}$. Sulfides are absent, and this is thought to reflect boiling and deposition of metals below the sea floor.

\section{Intracontinental rifts}

The type example of continental rifting in a submarine environment is the Red Sea. Extension began in the Red Sea in the late Oligocene to early Miocene, possibly in response to a mantle plume impinging on the Precambrian shield areas of the Arabian and Nubian plates (Menzies et al., 2002). In the early stages of opening, extensive deposits of Miocene evaporites developed at the flanks of the rift, and evaporite deposition continued until opening created a permanent connection to the Indian Ocean. Sea-floor spreading began in the presently active southern part of the Red Sea about 5 m.y. ago (Cochran, 1983). The rift basin is now more than $1,800 \mathrm{~km}$ long, 200 to $300 \mathrm{~km}$ wide, and 2,000 $\mathrm{m}$ deep. Active spreading is occurring in the south at a rate of about $2 \mathrm{~cm} / \mathrm{yr}$ and continues on land at the Afar Rift, which is presently $120 \mathrm{~m}$ below sea level in the Danakil depression. Several iron-manganesebarite deposits that occur on land in the Danakil depression formed less than 200,000 years ago when this part of the rift was submerged (Bonatti et al., 1972). At the north end of the Red Sea, the extension is more diffuse and is terminated at a left-lateral transform that extends into the Dead Sea.

The central part of the Red Sea contains 25 separate subbasins. Brine pools produced by dissolution of evaporite exposed on the flanks of the rift occur at the bottoms of most of these basins. In some cases, these cold brines are circulated into the volcanic basement where they are heated to temperatures close to those of mid-ocean ridge black smokers. Owing to their density, the resulting metalliferous fluids do not form buoyant hydrothermal plumes when they are discharged but sink back into the brine pools. Metalliferous deposits precipitated from these hot brines occur in 16 of the 25 deeps (Scholten et al., 2000). The Atlantis II Deep contains the largest pool of hot brine, $70 \mathrm{~m}$ thick and covering an area of about $10 \times 6 \mathrm{~km}$ (Bäcker and Richter, 1973). The brine is continuously replenished by hot fluid at a rate of about 670 $\mathrm{kg} / \mathrm{s}$ (ranging from $280 \mathrm{~kg} / \mathrm{s}$ up to a maximum of $1,000 \mathrm{~kg} / \mathrm{s}$ : Hartmann, 1980; Anschutz and Blanc, 1996), so that the entire pool has maintained a stable temperature of about $60^{\circ} \mathrm{C}$ for at least the last $40 \mathrm{yr}$. Fe and Mn oxyhydroxides are precipitated at the interface between the lower brine and the more oxidized upper layers of the brine pool (Pottorf and
Barnes, 1983; Zierenberg and Shanks, 1983). The Fe and Mn oxides accumulate, together with $\mathrm{Fe}$-rich clay minerals, as a blanketlike deposit of metalliferous mud. In the Atlantis II Deep, this sediment has an average thickness of $8.5 \mathrm{~m}$ (up to $25 \mathrm{~m}$ ) and covers nearly the entire bottom of the sub-basin $\left(57 \mathrm{~km}^{2}\right)$, thus more closely resembling iron formation than other types of sea-floor mineral deposits. Similar but smaller occurrences of metalliferous sediment occur in the Shaban, Kebrit, Thetis, Nereus, Gypsum, and Vema Deeps (Fig. 1; Scholten et al., 2000). Because the lower brines are anoxic, the precipitation of sulfide-facies sediment occurs periodically in the muds of the Atlantis II Deep and in the smaller Shaban and Kebrit Deeps, locally associated with small sulfide chimneys (Blum and Puchelt, 1991; Scholten et al., 2000). The lack of oxygen favors the preservation of the sulfides and limits bacterially mediated sulfide oxidation. The absence of macrofauna also means that the finely laminated metalliferous sediments are not disturbed by bioturbation.

\section{Submarine volcanic arcs}

Volcanic arcs, both subaerial and submarine, account for about 26 percent of the global magmatic budget (Perfit and Davidson, 2000). Approximately half of the volcanic arcs (ca. $22,000 \mathrm{~km}$ ) are at least partly to completely submerged. The dominantly submarine volcanic arcs are of two main types: intraoceanic arcs and "transitional" or island arcs (de Ronde et al., 2003). Transitional arcs are the most common, with a cumulative length of $14,800 \mathrm{~km}$, and include many of the island archipelagos of the western Pacific. They are developed mainly at the margins of continents, commonly with a basement of young continental crust or old arc crust. Intraoceanic arcs, which have a cumulative length of 7,000 km, occur on a basement of dominantly oceanic crust.

The intraoceanic arcs of the western Pacific region have lengths of more than $1,000 \mathrm{~km}$ each, but the active volcanic front is typically only 50 to $70 \mathrm{~km}$ wide. The distance between the trench and the arc is typically $\leq 100 \mathrm{~km}$ but can be as much as $200 \mathrm{~km}$ (e.g., Izu-Bonin arc). On the Izu-Bonin arc, there are 45 major stratovolcanoes along the 1,300-km active volcanic front, and 26 are submarine (Yuasa et al., 1991). On the 1,700-km-long Tonga-Kermadec arc, there are at least 90 volcanoes, and more than 70 are submarine (de Ronde et al., 2003). The spacing between the volcanoes ranges from 27 to $55 \mathrm{~km}$ and is typically quite regular. Most of the volcanoes are simple cones, with basal diameters of $30 \mathrm{~km}$ and heights of 1 to $2 \mathrm{~km}$ above the surrounding sea floor. About one-third of the volcanoes have summit calderas, the largest being 5 to 6 $\mathrm{km}$ in diameter. Most summit calderas occur at relatively shallow water depths of $<1,000 \mathrm{~m}$ (95\% are shallower than 1,600 m; Fig. 2).

Early arc volcanism is typically basaltic and tholeiitic (Stern and Bloomer, 1992; Pearce and Peate, 1995), becoming more andesitic and calc-alkaline as the arc crust thickens and the depth and extent of fractionation of the magmas increases. The arc magmas are mainly products of partial melting caused by the addition of $\mathrm{H}_{2} \mathrm{O}$ and other volatiles to the subarc mantle from subducted sediments and hydrated oceanic crust. Fluids from the subducted oceanic crust not only trigger partial melting in the mantle wedge but also cause oxidation of the magma and are transport agents for some of the 
trace elements that are enriched in arc lavas. Island-arc basalt (IAB) differs from MORB by having (1) higher and more variable $\mathrm{H}_{2} \mathrm{O}$ contents (up to 6 wt \%: Gaetani et al., 1993), (2) higher concentrations of $\mathrm{CO}_{2}$ (up to 2 wt \%: Jambon, 1994), (3) higher $\mathrm{Fe}_{2} \mathrm{O}_{3} / \mathrm{FeO}$ (Gill, 1981), and (4) enrichments of large ion lithophile elements (LILE) such as Ca, Ba, Cs, K, $\mathrm{Rb}$, and $\mathrm{Sr}$, which are soluble in fluids driven off the subducting slab (e.g., Macdonald et al., 2000). Although volcanic arcs account for only a small proportion of submarine volcanism (2-5 km³/yr: Arculus, 1999), considering the composition of the arc magmas, the flux of volatiles from these systems is likely much greater than that from the mid-ocean ridges.

The summit calderas of the largest volcanoes commonly contain more silicic lavas, including distinctive postcaldera dacite domes. Explosive caldera-forming eruptions have occurred at depths of at least $1,500 \mathrm{~m}$ on both the Izu-Bonin and Kermadec arcs, and dacitic and rhyolitic pyroclastic rocks are common in the calderas (e.g., Fiske et al., 2001; Smith et al., 2003). High-temperature hydrothermal venting is mainly restricted to the largest calderas, which provide the necessary structural control for focusing hydrothermal fluids. The common postcaldera lava domes also indicate the presence of shallow magma that can drive hydrothermal activity. Hydrothermal vents are almost always localized along the caldera walls or on the postcaldera domes (e.g., Fiske et al., 2001; Wright et al., 2002). Other volcanoes that lack summit calderas commonly have a carapace of permeable volcanic breccias and tephra with only diffuse hydrothermal venting (de Ronde et al., 2003). On the Mariana and Kermadec arcs, which are the most completely surveyed, hydrothermal plumes have been found above one-third of the submarine volcanoes (de Ronde et al., 2003). The nature of the hydrothermal activity responsible for all of the plumes is not yet well characterized. Some are related to high-temperature hydrothermal venting and black smoker activity (e.g., 3 of the 12 plumes on the Mariana arc), but many appear to be due to passive degassing or quiescent eruptions rather than hightemperature hydrothermal activity (Massoth et al., 2003; Embley et al., 2004).

The Izu-Bonin arc is the type example of a primitive intraoceanic arc (Fig. 5A). Volcanoes in the northern part of the arc include both basaltic compositions and abundant silicic lavas of low $\mathrm{K}$, calc-alkaline affinity, whereas those in the south are dominantly basaltic to andesitic (Stern and Amira, 1998). Nine of the 26 submarine volcanoes along the arc have summit calderas and are known to be hydrothermally active (Ishibashi and Urabe, 1995; Glasby et al., 2000). The largest hydrothermal system in the northern part of the arc occurs in the 5-km-diameter Kita-Bayonnaise caldera of the Myojin knoll volcano at a depth of 1,300 m. Extensive patches of hydrothermally altered pumiceous sediment, scattered outcrops of sulfide and barite, and breccias containing quartz-pyrite \pm barite stockworks occur along the caldera wall and on a 500$\mathrm{m}$-high volcanic cone at the center of the caldera (Iizasa et al., 1999). The largest area of hydrothermal venting (Sunrise deposit) has a maximum recorded vent temperature of $278^{\circ} \mathrm{C}$, and active barite and sulfide chimneys occupy an area $400 \mathrm{~m}$ in diameter, although the sulfide outcrop is not continuous. The nearby Myonjinsho volcano (Iizasa et al., 1992), and Suiyo seamount farther south (Ishibashi et al., 1994; Tsunogai et al., 1994), host similar small massive barite and polymetallic sulfide deposits. The vents at Suiyo seamount have a temperature of $317^{\circ} \mathrm{C}$ and are characterized by a higher chlorinity than seawater, notable $\mathrm{Ca}$ enrichment and $\mathrm{Na}$ depletion, and high $\mathrm{CO}_{2}$ concentrations, interpreted to reflect a magmatic component in the fluids.

The Mariana arc, south of the Izu-Bonin chain, includes at least 50 volcanoes along its 1,200-km length (Fig. 5A). A cluster of hydrothermally active volcanoes, known as the Kasuga seamounts, occurs at the junction of the Izu-Bonin and Mariana arcs (McMurtry et al., 1993), and 12 other volcanoes on the arc front have notable hydrothermal plumes (Embley et al., 2004). High-temperature black smoker vents occur on at least one volcano (East Diamante), but the extent of hydrothermal venting at the other volcanoes is uncertain. Many of the volcanoes host significant deposits of native sulfur, as well as Fe-Mn oxides or Fe-rich clay minerals (e.g., nontronite) but lack high-temperature vents (e.g., Stueben et al., 1992a; McMurtry et al., 1993). In one shallow submerged caldera at a depth of $200 \mathrm{~m}$ (Esmeralda Bank), the deposits of native sulfur are up to $1 \mathrm{~m}$ in thickness and cover an area 400 $\mathrm{m}$ in diameter. These deposits are associated with turbulent gas plumes and low $\mathrm{pH}$ anomalies $(\mathrm{pH}=5.6)$ caused by injection of $\mathrm{CO}_{2}$ and $\mathrm{SO}_{2}$ into the water column (Stueben et al., 1992a).

The Kermadec chain, north of New Zealand, hosts 13 submarine volcanoes along a $260-\mathrm{km}$-long section of the arc (de Ronde et al., 2001, 2003). The volcanoes occur at water depths of 220 to $1,600 \mathrm{~m}$, and three of the largest volcanoes have summit calderas up to $3.5 \mathrm{~km}$ in diameter and $450 \mathrm{~m}$ deep (Wright and Gamble, 1999). One of the largest and deepest calderas is on Brothers volcano at a water depth of $1,600 \mathrm{~m}$ (Wright et al., 1998, 2002). Active black smoker vents and massive sulfide deposits occur on the wall of the caldera, and lower temperature venting and apparent magmatic degassing occur on a 350-m-high dacitic volcanic cone on the caldera floor (de Ronde et al., 2001, 2005). The hydrothermal plumes above Brothers volcano reach nearly $700 \mathrm{~m}$ in height, with a chemically distinct plume characterized by high magmatic volatile concentrations emitted from the dacitic volcanic cone (Baker et al., 2003; Massoth et al., 2003).

The discovery of polymetallic sulfide deposits on volcanoes at the volcanic fronts of arcs contrasts with the interpreted settings of most ancient VMS deposits, which are considered to have formed mainly during arc rifting. A number of aspects of this setting also result in dramatically different deposit types than those found on the mid-ocean ridges and in deeper back-arc basins. The shallow water depths result in widespread boiling and generally lower temperatures of hydrothermal venting (Fig. 3), and boiling may occur at lower temperatures due to the high gas contents of the fluids. There is clear evidence of the direct input of magmatic volatiles, including sulfur-rich fumaroles and low $\mathrm{pH}$ vent fluids, similar to magmatic-hydrothermal systems in subaerial arc volcanoes (Tsunogai et al., 1994; de Ronde et al., 2005).

\section{Intraoceanic back-arc basins}

The majority of the known high-temperature vents in the western Pacific occur at intraoceanic back-arc spreading centers (e.g., Lau basin, North Fiji basin, Mariana trough). 

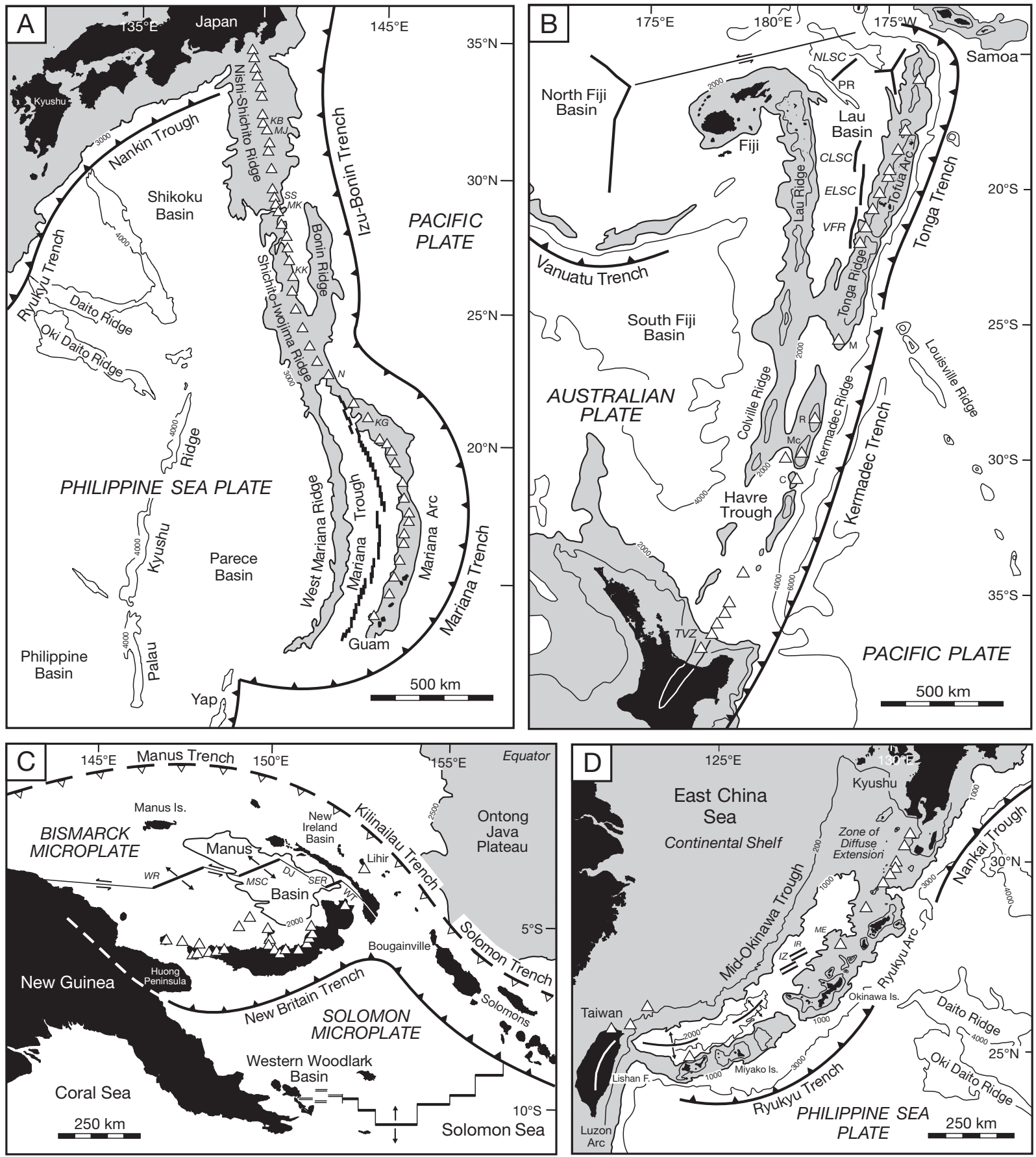

- Active subductionzone $\longleftarrow$ Inactive subductionzone $\Delta$ Arc stratovolcano 々 Spreading center

FIG. 5. Tectonic settings and geometry of plate boundaries in several arc and back-arc settings of the western Pacific region. A. Izu-Bonin and Mariana intraoceanic arc and back-arc trough. $\mathrm{KB}=$ Kita-Bayonnaise volcano; $\mathrm{KG}=\mathrm{Kasuga}$ Seamounts; KK = Kaikata Seamount; MJ = Myonjinsho volcano; N = Nikko Seamount. B. Lau basin and Tonga-Kermadec intraoceanic arc and back-arc basin $. \mathrm{C}=$ Curtis island; $\mathrm{CLSC}=$ Central Lau spreading center; ELSC = Eastern Lau spreading center; $\mathrm{M}=$ Monowai Seamount; $\mathrm{Mc}=\mathrm{McCauley}$ island; $\mathrm{NLSC}=$ Northern Lau spreading center; $\mathrm{PR}=$ Peggy Ridge; $\mathrm{R}=$ Raoul island; TVZ = Taupo Volcanic Zone; VFR = Valu Fa Ridge C. Transitional island arc and back-arc spreading centers of the Manus basin and Western Woodlark basin. DJ = Djaul fault; MSC = Central Manus back-arc spreading center; SER = Southeast rifts of the Eastern Manus back-arc spreading center; WR = Western Ridge of the Western Manus spreading center; WT = Weitin fault. D. Okinawa trough intracontinental back-arc basin. IR = Iheya Ridge; IZ = Izena cauldron; $\mathrm{ME}=$ Minami-Ensei knolls. The locations of major arc stratovolcanoes and submarine back-arc spreading centers are shown. Shaded contours correspond to the depths of major bathymetric features in each region, as discussed in the text. The maps are modified from Yuasa et al. (1991), Gamble and Wright (1995), Hawkins (1995), Auzende et al. (1995), Fryer (1995), Sibuet et al. (1995), and Taylor and Martinez (2003). 
Although there are no estimates of the magnitude of the hydrothermal flux from back-arc spreading centers, their contribution to the global flux is likely proportional to their length (i.e., about $20 \%$ of the mid-ocean ridge flux). Back-arc spreading centers develop after a prolonged episode of arc rifting, typically caused by oceanward migration and sinking of the subducting plate (i.e., slab rollback). During this time, voluminous felsic volcanism can occur, shedding large amounts of pumiceous material into the nascent back-arc rift (Clift, 1995). Examples of the earliest stages of rifting of an intracoceanic arc occur in several narrow depressions located immediately behind the Izu-Bonin arc (Ikeda and Yuasa, 1989; Fryer et al., 1990) and along the propagating tips of the northern and southern Mariana trough (Stern et al., 1990; Stern and Amira, 1998). These initial back-arc rifts are typically short troughlike features, $<100 \mathrm{~km}$ long and 30 to $40 \mathrm{~km}$ wide. The Sumisu rift, in the northern Izu-Bonin arc, hosts rhyolite domes and deposits of amorphous silica, barite, and hematitic chert (Urabe and Kusakabe, 1990).

Several millions of years may elapse before a back-arc rift is wide enough that passive upwelling of mantle material can occur, leading to true ocean-floor spreading. Back-arc basins typically do not contain true ocean floor until they are at least $200 \mathrm{~km}$ wide and the arclike and mantle melts become spatially separated (Taylor, 1995). Where the arc has been split, a distal remnant arc occurs beyond the back-arc region (e.g., West Mariana Ridge and Lau Ridge; Fig. 5A-B). The remnant arc is typically amagmatic, although arc magmas are erupted locally between the active volcanic front and the remnant arc (cross-arc volcanoes: Gamble and Wright, 1995; Fryer, 1995).

Back-arc spreading centers occur behind about half of the active submarine volcanic arcs and have a cumulative length of about 10,000 km, including both intraoceanic and continental margin settings. Most back-arc spreading centers of the western Pacific occur at water depths of about 2,000 m, slightly shallower than the mid-ocean ridges, but can range from $<1,500$ to more than $3,600 \mathrm{~m}$ deep in the Mariana trough. The spreading centers can be located as much as 500 $\mathrm{km}$ from the arc front, as in the North Fiji basin, to less than $20 \mathrm{~km}$, as in the southern Lau basin. Mature back-arc spreading centers resemble intermediate-rate mid-ocean ridges, implying similar rates of magma supply. However, rates of spreading in back-arc basins are highly variable, owing to the common oblique convergence of the plates, and can range from $<5$ to as much as $10 \mathrm{~cm} / \mathrm{yr}$ (e.g., Taylor et al., 1994; Taylor and Martinez, 2003). Volcanic arcs and related back-arc rifts are commonly affected by features of the subducting plate, such as subduction of ridge segments or seamount chains (e.g., Louisville ridge subducted beneath the Lau basin; Daito ridge subducted beneath the Okinawa trough; Fig. 5). This can cause segmentation of both the volcanic arc and back-arc region, enhanced magmatic activity, and abrupt transitions from broad zones of crustal thinning to deeper back-arc basins. Depths to the subaxial magma along back-arc spreading centers vary from 3.5 to as little as $1.1 \mathrm{~km}$, similar to mid-ocean ridges (Collier and Sinha, 1992). Back-arc basin basalts, or $\mathrm{BABB}$, like arc magmas, are enriched in volatiles and incompatible elements compared to MORB but are transitional between MORB and arc basalt (Stern et al., 1990; Hawkins, 1995). These melts are derived mainly from the suprasubduction mantle, but the influence of the subducted slab is evident in the trace elements and isotopic systematics, including ${ }^{226} \mathrm{Ra},{ }^{230} \mathrm{Th},{ }^{10} \mathrm{Be},{ }^{4} \mathrm{He}, \mathrm{Pb}$, and $\mathrm{Sr}$ isotopes (e.g., Fouquet and Marcoux, 1995).

The first high-temperature hydrothermal vents in an intraoceanic back-arc setting were found in the central Mariana trough in 1986. The Mariana trough formed about 7 m.y. ago, when the West Mariana Ridge was separated from the Mariana $\operatorname{arc}$ (Fig. 5A), and the central part of the trough is now opening at a rate of 3 to $3.5 \mathrm{~cm} / \mathrm{yr}$ (Fryer, 1995). High-temperature hydrothermal activity occurs at an axial volcano of the back-arc spreading center at a depth of 3,600 to 3,700 m (Alice Springs vent field: Stueben et al., 1995). A number of back-arc volcanoes also occur immediately behind the arc front and host active hydrothermal vents (e.g., Forecast vent field: Ishibashi and Urabe, 1995).

The Lau basin (Fig. 5B) was among the first of the western Pacific arc and back-arc systems to be recognized as having formed by splitting of an island arc (Karig, 1970). Barite and amorphous silica were recovered from Peggy Ridge in the northern part of the Lau basin in 1975 (Bertine and Keene, 1975), although the significance of this discovery was unclear at the time. The northern part of the basin is at least 5 to 6 m.y. old, has a width of $600 \mathrm{~km}$, and is opening at a rate of about $10 \mathrm{~cm} / \mathrm{yr}$ (Hawkins, 1995). The main spreading center comprises a series of inflated ridge segments, each about 200 $\mathrm{km}$ in length, with axial depths of 2,300 to 2,400 m. They are generally very similar to mid-ocean ridges in their structure, degree of segmentation, and volcanic architecture, and they are erupting mostly MORB-like lavas, although there is also evidence of a plumelike source (Pearce et al., 1995). In the southern Lau basin, the spreading rate decreases to about 4 $\mathrm{cm} / \mathrm{yr}$, and the back-arc region has a width of only $200 \mathrm{~km}$. Spreading in this part of the basin began only in the last million years, and southward propagation of the rift gives rise to the classic V shape of a young back-arc basin. Here, spreading occurs along a series of short, 100-km-long ridges that step progressively eastward toward the volcanic front of the arc (Taylor et al., 1996). The southernmost spreading segment (Valu Fa Ridge) approaches to within $20 \mathrm{~km}$ of the arc and has a depth of only $1,700 \mathrm{~m}$. The lavas in this part of the Lau basin are more arclike, with a predominance of basaltic andesite and andesite (Hawkins, 1995; Pearce et al., 1995). South of the Valu Fa Ridge, the back-arc region is mainly an area of stretched arc crust with abundant normal faulting but no obvious spreading (Pelletier et al., 1998). Black smoker activity occurs both on the northern Lau spreading centers and in the southern Lau basin, and six high-temperature vent sites have been found between $15^{\circ} 20^{\prime} \mathrm{S}$ and $22^{\circ} 40^{\prime} \mathrm{S}$ (a distance of $800 \mathrm{~km}$ ). The deposits in the northern Lau basin are hosted by MORB and resemble typical mid-ocean ridge black smoker deposits (Lisitsyn et al., 1992; Bortnikov et al., 1993), whereas those in the south are hosted mainly by andesite and contain abundant barite, as well as much higher $\mathrm{Pb}, \mathrm{As}, \mathrm{Sb}$, Ag, and Au (e.g., Fouquet et al., 1993; Herzig et al., 1993; Table A2).

The North Fiji basin is the oldest and widest of the backarc basins (about 12 m.y. old: Auzende et al., 1995) and is located more than $500 \mathrm{~km}$ east of the Vanuatu arc. At this distance, the Wadati-Benioff zone no longer underlies the 
back-arc region. The spreading center is almost identical to a mid-ocean ridge, erupting MORB lavas with some influence of ocean island (OIB) components (Eissen et al., 1994). Hightemperature hydrothermal activity occurs in a 2 -km-wide axial graben atop the spreading ridge and has many similarities to high-temperature black smoker vents on the East Pacific Rise (Auzende and Urabe, 1994).

In areas of more complex microplate interactions, back-arc spreading can be highly asymmetric. This is evident in the relatively young (ca. 4 m.y.) and small Manus back-arc basin of Papua New Guinea (Fig. 5C). Here, oblique convergence between the Pacific plate and the Indo-Australian plate along the Manus-Kilinailau and New Britain trenches has resulted in transpression and counterclockwise rotation of the Bismarck microplate. This has caused wedgelike opening of the basin behind the New Britain arc and the development of large extensional transforms (e.g., Taylor et al., 1994). In the broad western and central parts of the basin, spreading on the main volcanic ridges and transform faults occurs at up to 10 $\mathrm{cm} / \mathrm{yr}$, but in the narrower, eastern part of the basin, opening decreases to $<2 \mathrm{~cm} / \mathrm{yr}$ (Martinez and Taylor, 1996; Taylor and Martinez, 2003). Black smoker vent fields occur in the axial zones of the main spreading ridges in the central part of the basin at water depths of $2,500 \mathrm{~m}$. As in the North Fiji basin, the hydrothermal fields are hosted by MORB and resemble mid-ocean ridge black smoker vents (Lisitsyn et al., 1993; Auzende et al., 2000). In contrast, deposits in the eastern part of the basin reflect more complex interactions with the adjacent New Britain arc (see below).

\section{Island arcs and related back-arc rifts}

In complex collisional zones, island arcs and related backarc rifts commonly occur in a basement of young continental crust or preexisting arc crust, involving a range of oceanic microplates and continental fragments and superposition of arc volcanism and back-arc rifting. The back-arc rifts may be either parallel or perpendicular to the plate boundary, and oblique collisions commonly result in hinged or radial extension in the back-arc region. The variety of tectonic elements involved is reflected in the complex chemistry of both the arc and back-arc magmas, which range from MORB-like compositions to medium and high $\mathrm{K}$ calc-alkaline andesite, and there can be considerable overlap of magma sources, with arclike magmas erupted in the back-arc region. Felsic volcanic rocks are abundant, resulting from fractional crystallization of magmas trapped in the thickened arc crust. In areas where this crust is actively rifting, large calderalike sea-floor depressions may develop, such as the DESMOS cauldron in the eastern Manus basin and the Izena cauldron in the Okinawa trough (see below).

In the easternmost part of the Manus basin, arc volcanism and back-arc rifting are occurring in a basement of Eocene to Oligocene arc crust immediately north of New Britain (southeast rifts, Fig. 5C). A 60-km-wide extensional zone has developed in the old arc crust and is likely the precursor of a backarc spreading center, although the absence of magnetic lineations indicates that true ocean-floor spreading is not yet occurring (Martinez and Taylor, 1996). A series of en echelon volcanic ridges, 20 to $30 \mathrm{~km}$ long, $<5 \mathrm{~km}$ wide, and 500 to 700 $\mathrm{m}$ high, occupy the zone of extension between two large-scale transform faults (Djaul and Weitin faults). Lavas erupted along the ridges are dominantly calc-alkaline and include the complete series from basalt to rhyolite (Kamenetsky et al., 2001; Binns et al., 2002). The lavas are highly vesicular, reflecting the higher $\mathrm{H}_{2} \mathrm{O}$ contents of the melts, and have strong geochemical affinities, including $\mathrm{Pb}$ and $\mathrm{Sr}$ isotopes, to the adjacent New Britain arc (Sinton et al., 2003). Two of the volcanic ridges host high-temperature hydrothermal vents (Pual Ridge and SuSu knolls: Binns and Scott, 1993; Binns et al., 2002). A third vent field occurs in the DESMOS cauldron, which is located in the extended crust between the ridges. Hydrothermal venting on Pual Ridge (referred to as the PACMANUS site) occurs along a 10-km strike length at the crest of the ridge in coherent andesite and blocky dacite lava flows and volcaniclastic rocks. Drilling in these areas during ODP Leg 193 recovered variably altered dacite, anhydrite-cemented breccias, and sulfide-impregnated volcaniclastic rocks from the top of the ridge to a depth of $380 \mathrm{~m}$ below the sea floor. Polymetallic sulfides at the sea floor are distinguished from the black smoker deposits in the central Manus basin by their higher $\mathrm{Au}, \mathrm{Ag}, \mathrm{Pb}, \mathrm{As}, \mathrm{Sb}$, and $\mathrm{Ba}$ contents (Scott and Binns, 1995; Moss and Scott, 2001; Binns et al., 2002). Two of the vent fields are characterized by distinctive advanced argillic alteration of the lavas, including disseminated pyrite, minor alunite, and abundant elemental sulfur (e.g., Gemmell et al., 1999; Gena et al., 2001), similar to that observed on some arc-front volcanoes.

Complex collisional zones, such as in the eastern Manus basin, commonly have a diverse regional metallogeny. For example, in the New Ireland basin, adjacent to the eastern Manus basin, a young volcanic arc (Tabar-Feni island chain) has developed in the old fore-arc crust of New Ireland in response to the northward subduction of the Solomon microplate (Fig. 5C). The young arc consists of a series of Pliocene to Pleistocene alkaline volcanoes formed by melts that have risen along transfer faults related to the opening of the Manus basin and a bend in the New Britain trench (McInnes and Cameron, 1994; McInnes et al., 2001). The Tabar-Feni chain is best known for the Luise volcano on the island of Lihir, which is the site of the giant Ladolam epithermal gold deposit (Carman, 2003). A number of submarine volcanoes of similar composition also occur immediately south of Lihir, at a water depth of about 1,000 m (Petersen et al., 2002). One of these volcanoes (Conical seamount) hosts an eroded stockwork of gold-rich polymetallic veins with many similarities to the epithermal-style gold mineralization in the nearby Ladolam deposit on Lihir (Petersen et al., 2002; Gemmell et al., 2004).

Shallow submarine hydrothermal activity with distinctive epithermal characteristics also has been found at the southern end of the Kermadec arc, where active rifting of the Havre trough extends onto the continental shelf of New Zealand and eventually merges onshore with the Taupo Volcanic Zone (Fig. 5B; Wright, 1992; Gamble and Wright, 1995). The submarine extension of the Taupo zone is about 40 to $50 \mathrm{~km}$ wide and consists of a narrow back-arc graben (Ngataro rift), which is opening at about $0.7 \mathrm{~cm} / \mathrm{yr}$, and a series of arc volcanoes that are continuous with the southern Kermadec chain (Whakatane seamount, White Island, and Whale Island: Parson and Wright, 1996). Near White Island, several shallow 
submarine grabens occur in the Mesozoic graywacke basement at depths of 170 to $190 \mathrm{~m}$ (Whakatane graben and the White Island trough). These grabens host active submarine hot springs and gas-rich vents at temperatures of up to $200^{\circ} \mathrm{C}$ (Pantin and Wright, 1994; Stoffers et al., 1999). Large chimneys and mounds of anhydrite occur at several of the vents, and others are depositing abundant native sulfur, as well as arsenic, antimony, and mercury sulfides. The mercury-depositing vents are analogous to several mercury-rich geothermal systems onshore and illustrate the common juxtaposition of both subaerial and submarine hydrothermal systems in transitional arc environments.

Similar widespread hydrothermal activity is occurring on the shallow flanks and in the breached calderas of numerous arc volcanoes in the Mediterranean Sea (e.g., Honnorez et al., 1973; Varnavas and Cronan, 1991; Cronan et al., 1995). The Tyrrhenian Sea is a fragment of the ancient Tethys sea floor in which several volcanic arcs and related back-arc basins have developed in response to northward subduction of the African plate beneath Europe (Beccaluva et al., 1985). The Aeolian arc, which includes the presently active subaerial volcanoes at Stromboli, Panarea, and Vulcano, also includes a number of submerged volcanoes, ranging from alkaline in the south to calc-alkaline in the north. Distinctive $\mathrm{Ba}, \mathrm{Pb}, \mathrm{As}, \mathrm{Sb}$, $\mathrm{Hg}, \mathrm{Ag}$, and Au-rich polymetallic sulfides occur at a depth of $600 \mathrm{~m}$ on the Palinuro seamount (Minniti and Bonavia, 1984; Dekov and Savelli, 2004) and also on a shallow (<100 m) submarine volcanic complex on the flank of Panarea (Marani et al., 1997; Table A2). The combination of continental basement, sediment input, and shallow water depths account for the complex mineralogy and chemistry of the hydrothermal precipitates.

\section{Rifted continental margins}

A number of submarine arc and back-arc systems are developed entirely in a basement of continental crust, with extension occuring in sediment-filled basins at the continental margin. These settings are characterized by an abundance of crustal melts, more extensive magmatic differentiation in deep-seated magma bodies (at depths of $>3 \mathrm{~km}$ ), and abundant silicic volcanism (e.g., Menzies et al., 2002). Because of the thick continental lithosphere, extension in the back-arc region is distributed over a larger area than in oceanic crust. Variations in the rate of convergence and the angle of offshore subduction also can lead to successive splitting of arcs away from the edge of the continent. This has occurred many times along the margins of eastern China and Siberia, most notably with the opening of the Japan Sea at about $30 \mathrm{Ma}$ and the Yamato basin at about $15 \mathrm{Ma}$, the latter associated with rifting of the Honshu arc and the formation of the Kuroko deposits (Ohmoto, 1983). The most recent in this succession of marginal basins is the presently active Okinawa trough backarc basin behind the Ryukyu volcanic arc in the East China Sea (Fig. 5D).

The Okinawa trough and Ryukyu arc are the type examples of a continental margin arc and back-arc rift. They extend for $1,200 \mathrm{~km}$ from the Kagoshima graben in Kyushu, Japan, to the Lishan fault zone in northern Taiwan (Fig. 5D). The most recent phase of rifting of the continental margin began about 2 m.y. ago in response to oblique northward subduction of the
Philippine Sea plate (Sibuet et al., 1998). The rate of opening is 2 to $4 \mathrm{~cm} / \mathrm{yr}$, but true sea-floor spreading has not started and there is no oceanic crust exposed. The northern part of the back-arc region is an area of diffuse extensional faulting, $230 \mathrm{~km}$ wide, with water depths of only a few hundred meters. In the south, the back-arc rift is up to 2,300 $\mathrm{m}$ deep but only 60 to $100 \mathrm{~km}$ wide. This variation in the depth and style of rifting reflects major differences in the thickness of the crust, which ranges from $30 \mathrm{~km}$ in the north to only $10 \mathrm{~km}$ in the south (Sibuet et al., 1995). The northern Okinawa trough also has a very thick sedimentary cover of up to $8 \mathrm{~km}$, decreasing to about $2 \mathrm{~km}$ in the south. Heat-flow measurements in the mid-Okinawa trough are among the highest recorded in Pacific marginal basins, in part resulting from this sediment cover. The basin sediments are dominated by terrigenous material with a high organic matter content, which has produced local concentrations of hydrocarbons, including methane hydrates, in the sediment-filled basins (Glasby and Notsu, 2003). Locally, significant hydrocarbon accumulations can develop in such settings, which are better known for base metal mineralization, including in the Miocene oil fields on the flank of the Honshu arc of Japan and today in the back-arc regions of Sumatra and Java.

In the central part of the Okinawa trough, back-arc volcanism occurs within several en echelon grabens at depths of 2,000 to $2,500 \mathrm{~m}$ (Sibuet et al., 1995). The individual grabens are 50 to $100 \mathrm{~km}$ long and 10 to $20 \mathrm{~km}$ wide and contain a number of volcanic ridges or elongate volcanoes, similar to Pual Ridge in the eastern Manus basin. The volcanic ridges comprise a nearly bimodal suite of vesicular basalt, andesite, and rhyolite of calc-alkaline affinity (Kimura et al., 1988; Shinjo and Kato, 2000). The origin of the rhyolite is debated and may involve either island arc-type magmas (e.g., Ishizuka et al., 1990), melting of older continental crust, or fractional crystallization of a back-arc basaltic source (Honma et al., 1991). Widespread hydrothermal activity occurs on or adjacent to the volcanic ridges (Gamo et al., 1991; Ishibashi and Urabe, 1995; Nakashima et al., 1995). However, the largest vent field (JADE) is located in a $5 \times 6$-km and 300-m-deep structural depression known as the Izena cauldron, which resembles the DESMOS cauldron in the eastern Manus basin. The floor of the cauldron is dominated by basalt and andesite, with local dacite and rhyolite lava domes and a 20- to 30-mthick cover of rhyolite pumice and mudstone (Halbach et al., 1989). A central high-temperature vent field has maximum vent temperatures of $320^{\circ} \mathrm{C}$ and high gas contents in the vent fluids $\left(\mathrm{CO}_{2}, \mathrm{CH}_{4}\right.$, and $\left.\mathrm{H}_{2} \mathrm{~S}\right)$, which are thought to reflect magmatic degassing (Sakai et al., 1990); the high $\mathrm{CO}_{2}$ flux causes a $\mathrm{CO}_{2}$ hydrate seal to form just below the sea floor. Polymetallic sulfides in the JADE field are hosted by intensely altered, pumice-rich sediment with disseminated barite, kaolinite, and native sulfur, and the sulfides are distinctly rich in $\mathrm{Pb}, \mathrm{As}, \mathrm{Sb}, \mathrm{Hg}, \mathrm{Ag}, \mathrm{Au}$, and Ba (Halbach et al., 1989, 1993; Table A2). The Iheya Ridge (Clam site), $30 \mathrm{~km}$ north of the Izena cauldron, has a thicker cover of sediment and differs from the JADE site by the presence of abundant carbonates (manganoan calcite and rhodochrosite: Nakashima et al., 1995). Hydrothermal venting also occurs at the southern end of the Okinawa trough in the portion of the back-arc depression closest to Taiwan (Glasby and Notsu, 2003). 
Similar intracontinental back-arc rifts occur in the central Andaman trough north of Sumatra, at the eastern edge of the Sea of Okhotsk behind the Kurile arc, in the Bering Sea adjacent to Kamchatka, and along the western Antarctic peninsula. Bransfield strait, adjacent to the western Antarctic peninsula, is a sediment-filled rift between the inactive South Shetland Island arc and the Antarctic continent. This rift is underlain by 9 to $16 \mathrm{~km}$ of Mesozoic accreted material and, despite the low spreading rate, is characterized by high heat flow and the presence of thermogenic hydrocarbons in the sediments (Lawver et al., 1995; Klinkhammer et al., 2001). Quaternary volcanoes have erupted through this sediment and are composed mainly of basalt and basaltic andesite, with minor dacite and rhyodacite (Keller et al., 2002). Polymetallic sulfides recovered from the summits of the volcanoes have high concentrations of $\mathrm{Pb}, \mathrm{As}, \mathrm{Sb}, \mathrm{Hg}, \mathrm{Ag}$, and $\mathrm{Ba}$, similar to the deposits in the Okinawa trough, reflecting the continental basement and the sediments in the rift (Petersen et al., 2004; Table A2).

The western Woodlark basin is an unusual example of rifted continental crust where sea-floor spreading is propagating into the margin of easternmost Papua New Guinea (Fig. 5C). The spreading center lacks a clear relationship to a subduction zone and therefore is not a typical back-arc rift. Rather, opening of the basin appears to be related to oblique convergence of the Pacific and Indo-Australian plates and rotation of the Solomon microplate (Benes et al., 1994; Taylor et al., 1995). The eastern end of the spreading ridge is being subducted beneath the Solomon arc, while the western end is propagating at $12 \mathrm{~cm} / \mathrm{yr}$ into continental fragments of eastern Papua New Guinea. Rifting of the continental crust has created a series of short sub-basins which contain MORB-like basalt, ferrobasalt, and andesite, with sodic rhyolite erupted at one volcano near the axis of the spreading center (Franklin seamount: Binns et al., 1993). Hydrothermal activity associated with the felsic volcanic rocks has produced extensive deposits of barite, amorphous silica, and Fe oxides with anomalous gold concentrations (Binns et al., 1993, 1997).

\section{Geochemistry of Hydrothermal Fluids and Metal Concentrations}

The different volcanic and tectonic settings of sea-floor hydrothermal systems involve a number of different sources and pathways for the generation of high-temperature fluids. The major variables controlling fluid compositions have been determined from mid-ocean ridge black smokers, but a wide range of hydrothermal fluids also has been recognized in nonMORB settings. In this section, we examine the origins of end-member hydrothermal fluids at mid-ocean ridges, in ultramafic-dominated and sedimented environments, and in arc and back-arc settings.

\section{Fluids at mid-ocean ridges}

The complex chemistry of heated seawater and its behavior as a hydrothermal fluid were first established by the experiments of Bischoff and Seyfried (1978) and Bischoff and Rosenbauer (1983). These early experiments, and subsequent experiments involving reactions between seawater and basalt, closely matched the findings of Edmond et al. (1979a, b), who analyzed the first ridge-crest hydrothermal fluids from the
Galapagos hot springs. Subsequent sampling of vents on the East Pacific Rise and the Juan de Fuca Ridge (Edmond et al., 1982; Von Damm et al., 1985a) and modeling of fluid-mineral equilibria led to the present detailed understanding of hightemperature fluids in basalt-hosted submarine hydrothermal systems (Janecky and Seyfried, 1984; Bowers et al., 1985; Seyfried, 1987). Time-series studies, involving repeated sampling of individual black smokers (e.g., Campbell et al., 1988), showed that the temperature, $\mathrm{pH}$, salinity, oxidation state, and concentrations of major elements are remarkably stable at decade time scales. This was recognized as reflecting the strong chemical buffering of the fluids in equilibrium with a greenschist-facies alteration mineral assemblage (Bowers et al., 1988; Von Damm, 1988). However, subsequent time series also revealed considerable short-term ( $<10 \mathrm{yr}$ ) fluctuations in vent-fluid compositions, particularly salinity and gas concentrations, that were coincident with seismic events, dike intrusions and volcanic eruptions, including so-called "megaplume" events (e.g., Butterfield and Massoth, 1994; Butterfield et al., 1994a; Massoth et al., 1994). These variations have been attributed to subsea-floor phase separation, which is now considered to play a role in most high-temperature sea-floor hydrothermal systems (Von Damm et al., 1997; Butterfield, 2000; Von Damm, 2000).

Many of the chemical characteristics of sea-floor hydrothermal fluids result simply from the heating of seawater. At $150^{\circ} \mathrm{C}$, anhydrite, which has retrograde solubility, will precipitate, and the concentrations of dissolved $\mathrm{Ca}$ and $\mathrm{SO}_{4}$ decrease sharply, with $\mathrm{SO}_{4}$ reaching nearly zero concentration at temperatures above $400^{\circ} \mathrm{C}$ (some $\mathrm{SO}_{4}$ is also reduced to hydrogen sulfide by reaction with ferrous $\mathrm{Fe}$ in the rock). At $250^{\circ} \mathrm{C}$, a compound referred to as magnesium-hydroxy-sulfate hydrate (MHSH) also begins to precipitate from seawater (Janecky and Seyfried, 1983), and considerable acidity is generated by the reaction $\mathrm{Mg}^{2+}+2 \mathrm{H}_{2} \mathrm{O}=\mathrm{Mg}(\mathrm{OH})_{2}+2 \mathrm{H}^{+}$. The quantitative removal of $\mathrm{Mg}$ and $\mathrm{SO}_{4}$ from the fluid is the basis for the end-member fluid model of Edmond et al. (1979a, b) and Von Damm et al. (1985a). In this model, the concentrations of major elements measured at different temperatures can be extrapolated back to a common high-temperature end member along mixing lines between seawater and an undiluted (i.e., zero $\mathrm{Mg}$ or zero $\mathrm{SO}_{4}$ ) vent fluid (App. Table A3). Under some conditions, the uptake of $\mathrm{Mg}$ by altered rocks can be reversed, and $\mathrm{SO}_{4}$ can be added to the fluids from other sources (e.g., magmatic), so that the end-member model cannot be universally applied to all fluids (see below).

During convective hydrothermal circulation, seawater reacts with the crust at progressively higher temperatures, beginning in the recharge zone and reaching maximum temperatures of about $400^{\circ} \mathrm{C}$ in a high-temperature "reaction zone" at depth. Metals and reduced sulfur leached from the rock reach maximum concentrations in the reaction zone, and elements such as Si and Fe become major constituents of the hydrothermal fluids. At temperatures of about $400^{\circ} \mathrm{C}, \mathrm{SiO}_{2}$ concentrations approach quartz saturation and, because quartz solubility is pressure dependent, the silica concentration in fluids vented at the sea floor can be used to estimate the depth to the reaction zone, assuming no cooling has occurred (Von Damm and Bischoff, 1987, 1991). 
Reactions in felsic volcanic rocks are similar to those in basalt, although $\mathrm{pH}$ stabilizes more quickly to lower values, owing to a lack of Ca leaching to balance the removal of $\mathrm{Mg}$ from seawater. The few published experiments on seawaterrhyolite reactions (e.g., Hajash and Chandler, 1981) show a striking inverse correlation between the final $\mathrm{pH}$ of the solutions and the Si content of the rocks. However, much of the acidity in rhyolite-hosted hydrothermal vents may be due to the presence of volcanic gases in the hydrothermal fluids (see below). Small amounts of sediment in the volcanic pile also can strongly influence fluid compositions, particularly $\mathrm{pH}$. At the main Endeavour vent field on the Juan de Fuca Ridge, traces of buried sediment have resulted in unusually high concentrations of $\mathrm{CH}_{4}$ and $\mathrm{NH}_{3}$ in the hydrothermal fluids, and the $\mathrm{NH}_{3}$ buffers the vent fluids to a high $\mathrm{pH}$ (Lilley et al., 1993; Tivey et al., 1999).

Mid-ocean ridge black smoker fluids have in situ $\mathrm{pH}$ values of 4 to 5 , salinities of $<1$ to 8 wt percent $\mathrm{NaCl}$ equiv (avg 3.5, close to seawater), $\mathrm{CO}_{2}$ concentrations of $<5$ to $285 \mathrm{mmol}$ (avg 40), $\mathrm{H}_{2} \mathrm{~S}$ concentrations of $<0.1$ to $41 \mathrm{mmol}(\operatorname{avg} 7.3), \mathrm{H}_{2}$ concentrations of $<0.1$ to $1.8 \mathrm{mmol}$ (avg 0.2), and total metal concentrations of $<10$ to $1,300 \mathrm{ppm}$ (avg 290; Table A3). The $\mathrm{H}^{+}$concentration measured at $25^{\circ} \mathrm{C}$ spans a range of nearly three orders of magnitude, from low $\mathrm{pH}$ values of 2.5 to 5.8 (Fig. 6). The highest values are commonly encountered in older crust, such as at slow-spreading ridges, where the fluids have equilibrated with previously altered basalt rather than fresh rock and where sediment may be present in the reaction path. The lowest $\mathrm{pH}$ values are related to conductive cooling and precipitation of sulfides in the subsea-floor, which releases $\mathrm{H}^{+}$to the vent fluid. In fluids that have undergone phase separation, low $\mathrm{pH}$ has been measured both in the brine phase (e.g., at north Cleft on the Juan de Fuca Ridge: Butterfield and Massoth, 1994) and in the condensed vapor phase (e.g., at $9^{\circ}$ N EPR: Von Damm et al., 1997; Von Damm, 2000).

Dissolved $\mathrm{H}_{2}$ is the principal reductant in mid-ocean ridge hydrothermal fluids and is typically in the range of 0.1 to 0.2 mmol (i.e., close to pyrite-pyrrhotite-magnetite equilibrium). The narrow range of $\mathrm{H}_{2}$ and $\mathrm{H}_{2} \mathrm{~S}$ concentrations reflects equilibrium with a limited buffer assemblage, including immiscible sulfides and $\mathrm{Fe}$-bearing olivine in the most reduced fluids and a greenschist alteration assemblage, pyrite-magnetite-anhydrite-calcic plagioclase-epidote, in the most oxidized fluids (Seyfried et al., 1991; Seyfried and Ding, 1995). Dissolved sulfur concentrations are almost always in excess of dissolved metals, except in some high-chlorinity fluids (e.g., north Cleft, Table A3), and concentrations of up to $41 \mathrm{mmol} \mathrm{H}_{2} \mathrm{~S}$ have been measured in some low-chlorinity phase-separated fluids (e.g., $9^{\circ} \mathrm{N}$ EPR and Axial Volcano). Carbon dioxide concentrations range over two orders of magnitude, with typical mid-ocean ridge vent fluids having concentrations of 2 to 25 $\mathrm{mmol} / \mathrm{kg}$. Axial Volcano has the highest recorded $\mathrm{CO}_{2}$ concentration in a mid-ocean ridge setting $(285 \mathrm{mmol} / \mathrm{kg})$, in part because of phase separation but also from degassing of the subvolcanic magma (Butterfield et al., 1990, 1997). At most mid-ocean ridge black smokers, $\mathrm{CH}_{4}$ is a trace constituent of the fluids, mainly derived from the reduction of volcanic $\mathrm{CO}_{2}$ (Lilley et al., 1993, 1995).

Phase separation is the dominant control on both gas concentrations and chlorinity in sea-floor hydrothermal fluids.

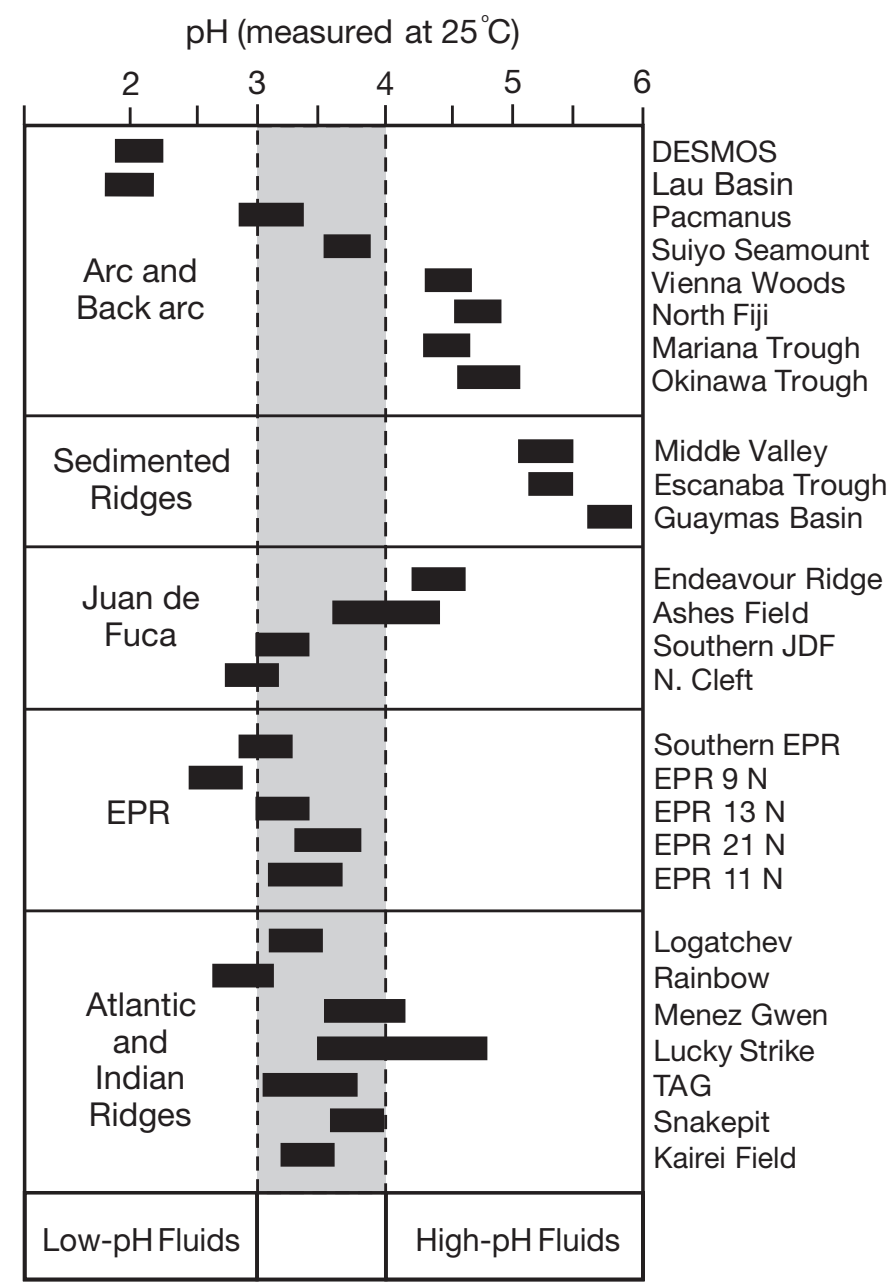

FIG. 6. Range of $\mathrm{pH}$ values in sea-floor hydrothermal vents (measured at $25^{\circ} \mathrm{C}$ ) in different volcanic and tectonic settings. The shaded bar represents the approximate range of $\mathrm{pH}$ values for most mid-ocean ridge vents. Examples with higher and lower $\mathrm{pH}$ values are discussed in the text. Data are from Table A3 and references therein.

The two-phase behavior of seawater was first documented in detail by the experiments of Bischoff and Rosenbauer (1984) and Bischoff and Pitzer (1985). When hydrothermal seawater intersects the two-phase curve at temperatures and pressures lower than the critical point for seawater $\left(407^{\circ} \mathrm{C}\right.$ and 298 bars; Bischoff and Rosenbauer, 1988), subcritical phase separation (i.e., boiling) produces a paired low-salinity vapor phase and gas-poor residual liquid. Some fluids have temperatures and pressures higher than the critical point; on cooling and/or depressurization to the critical curve, a small amount of high-salinity brine condenses from the bulk fluid. In both cases, gases partition into the less dense phase, and the major cations, including metals, become concentrated in the brine phase (Bischoff and Rosenbauer, 1987; Butterfield and Massoth, 1994). However, few high-temperature vents have compositions that are dominated by brine or vapor. In particular, the range of measured chlorinities $(0.06-2 \mathrm{X}$ seawater values; Table A3) is considerably less than that predicted to result from phase separation. This may be explained by the high 
density of the brine, which can become physically separated from the less dense vapor phase and concentrated in hightemperature reservoirs at depth (e.g., Bischoff and Rosenbauer, 1989). This model is supported by the high salinities observed in fluid inclusions in deep oceanic rocks and in ophiolites (e.g., up to 50 wt \% NaCl equiv), although chemically complex hypersaline liquids also may be exsolved from the adjacent crystallizing magma (Kelley and Delaney, 1987; Vanko et al., 1992; de Ronde, 1995; Kelley and Früh-Green, $2000,2001)$. At mid-ocean ridges, it is unlikely that exsolved magmatic brines are volumetrically significant, owing to the low $\mathrm{H}_{2} \mathrm{O}$ content of MORB, but such fluids may be produced by more water-rich magmas in arc environments. In either case, the presence of deep brines can significantly enhance metal solubility in the high-temperature reaction zones.

Isotopic data provide insight into sources of the various components in vent fluids in different tectonic settings. At mid-ocean ridges, $\delta \mathrm{D}_{\mathrm{H}_{2} \mathrm{O}}$ and $\delta^{18} \mathrm{O}_{\mathrm{H}_{2} \mathrm{O}}$ values of vent fluids are within a few per mil of seawater, with small deviations resulting from water-rock interaction at variable temperatures during recharge and in the reaction zone (App. Table A4). Lower $\delta \mathrm{D}$ values (to $-2.2 \%$ ) have been reported from at least one location $\left(9^{\circ} \mathrm{N} \mathrm{EPR}\right)$ and are considered to represent a small (3\%) magmatic water component (Shanks et al., 1995). Carbon dioxide $\delta^{13} \mathrm{C}$ values are between -4 and -9 per mil for the majority of sea-floor vents and are interpreted to reflect "mantle" sources (e.g., Von Damm, 1990). Methane $\delta^{13} \mathrm{C}$ values range from -9 to -26 per mil and have been interpreted to reflect high-temperature abiogenic $\mathrm{CH}_{4}$ production (e.g., Welhan, 1988). Hydrogen sulfide $\delta^{34} S$ values range from 1 to 7 per mil, similar to values for sulfides precipitated within the chimneys (Fig. 7). These values represent mainly leached sulfur from the basaltic substrate, with $<10$ percent contribution from inorganically reduced seawater sulfate (Shanks et al., 1995). Larger relative contributions of reduced seawater sulfate and higher $\delta^{34} S$ values are indicated for vents on slow-spreading ridges (e.g., TAG, Rainbow, and Logatchev fields on the Mid-Atlantic Ridge; Fig. 7), reflecting equilibration of the hydrothermal fluids with rocks that have already experienced a long history of seawater-rock interaction (Shanks, 2001). Strontium isotope data for vent fluids (Von Damm, 1990) and Pb isotope data for sulfides (e.g., Chen

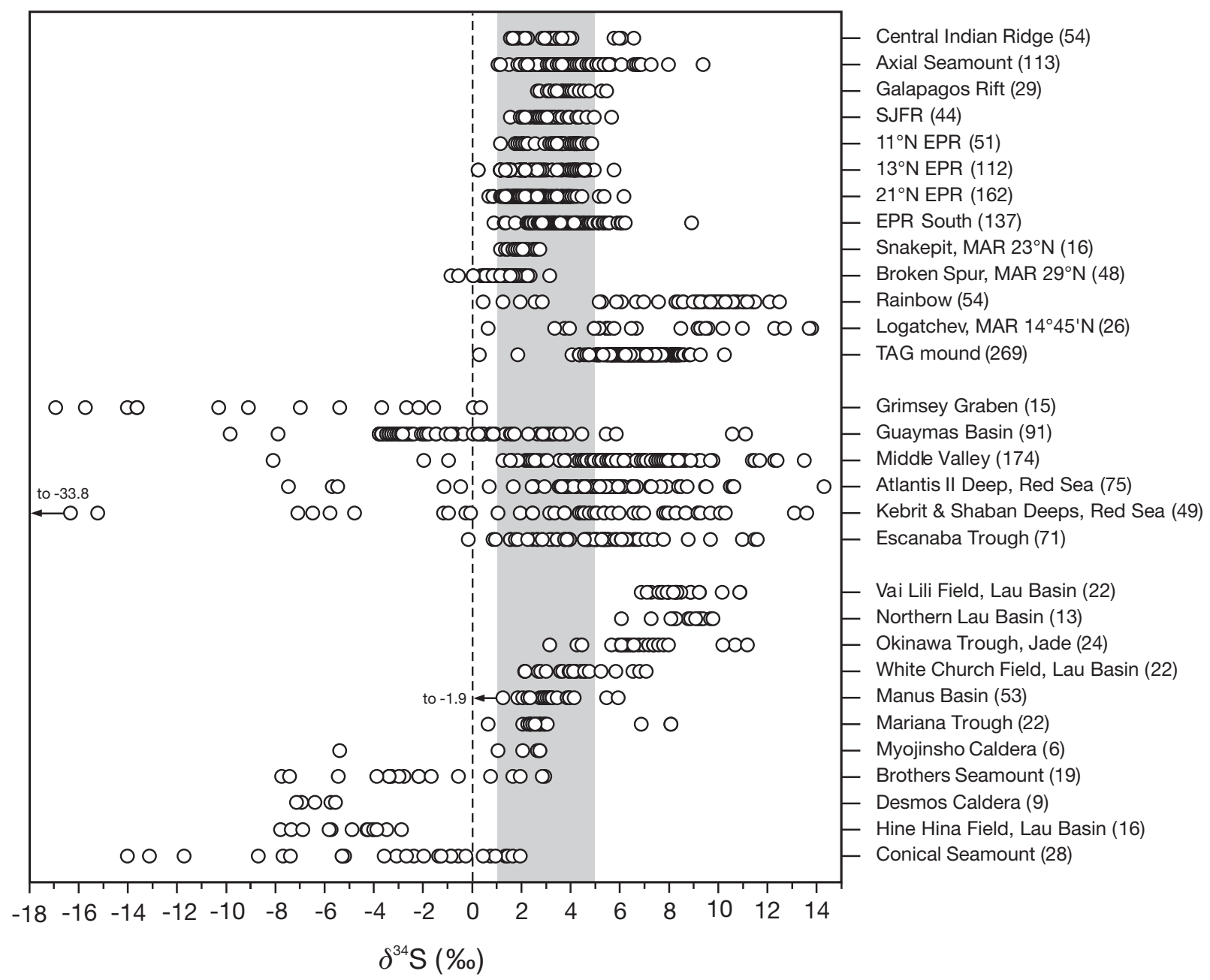

FIG. 7. Sulfur isotope compositions of representative sea-floor polymetallic sulfides. Data are shown for deposits on the mid-ocean ridges, in sedimented environments, and in arc and back-arc basin settings. See Figure 1 and Table Al for descriptions of the individual sites. The sources of data are listed in Appendix Table A5. The shaded bar encompasses 95 percent of the data from typical East Pacific Rise vents. Numbers in parentheses refer to number of analyses. 
et al., 1986; Godfrey et al., 1994) indicate a predominantly basaltic source for $\mathrm{Sr}$ and $\mathrm{Pb}$, with small to negligible contributions, respectively, from seawater.

Metal concentrations: Leaching of primary sulfides and the destruction of ferromagnesian minerals in basalt are the major sources of $\mathrm{Fe}, \mathrm{Mn}, \mathrm{Zn}$, and $\mathrm{Cu}$ in mid-ocean ridge vent fluids. Elements such as $\mathrm{Pb}$ and $\mathrm{Ba}$ are derived mainly from the dissolution of feldspars (e.g., Doe, 1994). The total concentrations of metals in black smoker fluids average close to 300 ppm (250 ppm Fe, 50 ppm Mn, 5-10 ppm Zn, 1-5 ppm $\mathrm{Cu}$, and $<0.1 \mathrm{ppm} \mathrm{Pb}$, with $1 \mathrm{ppm} \mathrm{Ba}$ ) and range from $<10$ ppm in vapor-phase fluids to more than 1,300 ppm in some brines (Table A3). The metal concentrations are strongly dependent on temperature, $\mathrm{pH}$, and chlorinity, although redox conditions in the high-temperature reaction zone also influence $\mathrm{Cu}$ and $\mathrm{Fe}$ concentrations in the end-member fluids (Seyfried and Ding, 1995; Seyfried et al., 1999).

Trace metal data for vent fluids are scarce, although the concentrations of some elements, such as $\mathrm{Co}, \mathrm{Se}, \mathrm{Mo}, \mathrm{Cd}$, As, $\mathrm{Sb}, \mathrm{Ag}$, and Au have been determined (Campbell et al., 1988; Von Damm, 1990; Butterfield et al., 1994a; Trefry et al., 1994; Seyfried et al., 2003). There are systematic differences in vent fluid compositions in mafic- or ultramafic-dominated environments (e.g., high concentrations of $\mathrm{Cu}, \mathrm{Fe}, \mathrm{Co}, \mathrm{Se}$, and $\mathrm{Ni}$ ) and in environments containing more evolved volcanic suites (e.g., high concentrations of $\mathrm{Zn}, \mathrm{Pb}, \mathrm{Ag}, \mathrm{As}, \mathrm{Sb}, \mathrm{Hg}, \mathrm{Ba}$, and $\mathrm{Au}$; see below). Superimposed on these source-rock controls is the strong temperature dependence on metal concentrations. Regardless of tectonic setting, sulfide assemblages formed at different temperatures almost always display consistent enrichments and depletions of certain metals. Elements such as Co, Se, and Mo are typically enriched in the highest temperature $\mathrm{Cu}$-rich chimneys $\left(\mathrm{ca} .350^{\circ} \mathrm{C}\right.$ ), whereas $\mathrm{Cd}, \mathrm{Pb}, \mathrm{As}, \mathrm{Sb}$, and $\mathrm{Ag}$ are concentrated in lower temperature fluids (ca. $250^{\circ} \mathrm{C}$ ) and enriched in $\mathrm{Zn}$-rich hydrothermal precipitates (e.g., Auclair et al., 1987; Fouquet et al., 1988; Hannington et al., 1991a; Herzig and Hannington, 1995). Considerable attention has been paid to the precious metal concentrations of sea-floor hydrothermal vents. Analyses of vent fluids and the quenched products of high-temperature black smokers indicate dissolved gold concentrations in the end-member fluids of 0.05 to $0.2 \mu \mathrm{g} / \mathrm{kg}$ (Hannington and Scott, 1989; Hannington et al., 1991b, and references therein). At these concentrations, a black smoker vent field with a mass flux of 100 to $500 \mathrm{~kg} / \mathrm{s}$ can transport a significant amount of gold to the sea floor over the life of a hydrothermal system. Metals that are transported at lower temperatures (e.g., $\mathrm{Au}, \mathrm{Ag}, \mathrm{As}, \mathrm{Sb}, \mathrm{Hg}, \mathrm{Tl}, \mathrm{Pb}$, and $\mathrm{Zn}$ ) tend to be concentrated in deposits forming in shallow water, above subseafloor boiling zones, and the extent of boiling is a major control on the bulk composition of the deposits that form at the sea floor (Hannington et al. 1999).

The concentrations of metals in mid-ocean ridge black smoker vents are considered by many to be too low to have produced the large-tonnage, Cu-rich VMS deposits in the geologic record (e.g., Scott, 1997). Mass-balance considerations for a typical EPR vent fluid (e.g., 2 ppm $\mathrm{Cu}$ and 5 ppm $\mathrm{Zn}$ ) require large volumes of hydrothermal fluid and leached rock to produce a major ore deposit, suggesting that other sources of metals must be involved. Brine inclusions of probable magmatic derivation in subsea-floor plutonic rocks locally contain daughter minerals of pyrite and chalcopyrite that indicate metal concentrations of up to 1000s of ppm $\mathrm{Fe}$ and $\mathrm{Cu}$ in the trapped fluids (Kelley and Delaney, 1987). Only a small contribution from such brines, mixed with modified seawater, could account for major metal concentrations in the vent fluids.

\section{Fluids in ultramafic-dominated environments}

In ultramafic rocks, a number of different reactions lead to significantly different fluid compositions, from low $\mathrm{pH}$, metal-rich fluids to high-pH, metal-depleted fluids over a wide range of temperatures (Wetzel and Shock, 2000; Allen and Seyfried, 2003). In the Rainbow and Logatchev vent fields on the Mid-Atlantic Ridge, the end-member fluids are products of high-temperature reactions with gabbroic subvolcanic intrusions and subsequent interaction with peridotite (Charlou et al., 2002). The low pH of the vent fluids results from $\mathrm{Ca}-\mathrm{Mg}$ exchange with pyroxene and the precipitation of tremolite and talc in the gabbroic rocks (Allen and Seyfried, 2003). The very high concentrations of $\mathrm{H}_{2}$ (up to $16 \mathrm{mmol}$ ) are mainly produced by serpentinization reactions (oxidation of ferrous iron in olivine: e.g., $15 \mathrm{Mg}_{2} \mathrm{SiO}_{4}+3 \mathrm{Fe}_{2} \mathrm{SiO}_{4}+$ $\left.23 \mathrm{H}_{2} \mathrm{O}=9 \mathrm{Mg}_{3} \mathrm{Si}_{2} \mathrm{O}_{5}(\mathrm{OH})_{4}+3 \mathrm{Mg}(\mathrm{OH})_{2}+2 \mathrm{Fe}_{3} \mathrm{O}_{4}+2 \mathrm{H}_{2}\right)$. Under these conditions, seawater sulfate is readily reduced to $\mathrm{H}_{2} \mathrm{~S}$, and this partly accounts for the high $\delta^{34} \mathrm{~S}$ values of the sulfides in the Rainbow and Logatchev fields (Fig. 7). Abundant $\mathrm{CH}_{4}$ is also produced during serpentinization, through a series of Fisher-Tropsch-like reactions that convert carbon dioxide to $\mathrm{CH}_{4}$ (e.g., $\mathrm{CO}_{2}+4 \mathrm{H}_{2}=\mathrm{CH}_{4}+2 \mathrm{H}_{2} \mathrm{O}$ : Kelley and Früh-Green, 1999; Früh-Green et al., 2004). Experiments by Berndt et al. (1996) and McCollom and Seewald (2001) showed that higher hydrocarbons as well as amorphous carbon and graphite also can be produced by these reactions, although the extent of inorganic synthesis of hydrocarbons during serpentinization remains uncertain.

Unusually high $\mathrm{Fe}$ concentrations in the end-member fluids at Rainbow and Logatchev (Table A3) are a result of leaching of magnetite from gabbro and altered peridotite by the low $\mathrm{pH}$ fluids. The $\mathrm{Fe}$ and $\mathrm{Ni}$ released from olivine and other ferromagnesian minerals form $\mathrm{Fe}-\mathrm{Ni}$ alloys and react with reduced sulfur to produce millerite, pentlandite, and pyrrhotite, which are locally abundant in the altered peridotite (Kelley and Früh-Green, 2000; Alt and Shanks, 2003). Millerite and pentlandite also occur in the massive sulfides at Rainbow and Logatchev (up to 2,580 ppm Ni at Rainbow and up to 600 ppm Ni at Logatchev: Mozgova et al., 1996, 1999; Murphy and Meyer, 1998; Bogdanov et al., 2002). The high concentrations of $\mathrm{Ni}$ and $\mathrm{Co}$ in these deposits are associated with notably elevated PGE (up to $190 \mathrm{ppb}$ Pt at Rainbow and up to 183 ppb Pt at Logatchev: Mozgova et al., 1999; Bogdanov et al., 2002). The Pt/Pd ratios of the sulfides are close to those of the host ultramafic rocks and are significantly higher than in other mid-ocean ridge black smokers (e.g., Pan and Xie, 2001).

In contrast to the ultramafic-hosted black smoker vents, the lower temperature, $75^{\circ} \mathrm{C}$ vents of the Lost City field have a high $\mathrm{pH}$ of 9 to 9.8 and low concentrations of metals, $\mathrm{SiO}_{2}$, and $\mathrm{H}_{2} \mathrm{~S}$ (Früh-Green et al., 2003). These fluids are buffered by equilibrium with brucite, which is present in abundance in 
veins and deposited directly on the sea floor. The formation of serpentine and other $\mathrm{Mg}$ silicates buffers Si to very low concentrations, and the high pH causes the hyperalkaline fluids to precipitate aragonite from the carbonate in seawater, forming the towering carbonate chimneys and large travertinelike deposits at Lost City (Kelley et al., 2001b; Palandri and Reed, 2004). Similar aragonite chimneys and deposits of $\mathrm{Mg}$ silicates have been found at cold seeps associated with serpentine diapirs in the Mariana fore-arc region (Fryer et al., 2000).

\section{Fluids in sedimented environments}

High-temperature seawater-sediment reactions have been characterized experimentally by Bischoff et al. (1981), Rosenbauer et al. (1983), Thornton and Seyfried (1987), Seewald et al. (1990, 1994), and Cruse and Seewald (2001). The experimental results correspond closely to observed vent fluid compositions from the Guaymas basin, Middle Valley, and the Escanaba trough (Bowers et al., 1985; Von Damm et al., 1985b; Campbell et al., 1988; Von Damm, 1991; Butterfield et al., 1994b; Campbell et al., 1994). The fluids are generally depleted in metals and enriched in the alkalies, boron, ammonia, and organic-derived hydrocarbons compared to seawaterbasalt systems. Chemical buffering by the sediment results in generally higher $\mathrm{pH}$ and more reduced hydrothermal fluids, giving rise to a class of deposits that is mineralogically quite different from those at sediment-starved mid-ocean ridges (Goodfellow and Zierenberg, 1999). Pyrrhotite tends to be the dominant Fe sulfide phase, and other minerals formed at low $f_{\mathrm{O}_{2}}$ are commonly present (e.g., Fe-rich sphalerite, arsenopyrite: Koski et al., 1985, 1988; Peter and Scott, 1988; Ames et al., 1993; Zierenberg et al., 1993). The lower venting temperatures compared to sediment-free mid-ocean ridges (e.g., $317^{\circ} \mathrm{C}$ in the Guaymas basin, $276^{\circ} \mathrm{C}$ at Middle Valley, $217^{\circ} \mathrm{C}$ in the Escanaba trough) and the higher $\mathrm{pH}$ account for the lower metal concentrations at the sea floor. However, the presence of a high-temperature $\mathrm{Cu}$-rich zone beneath the Bent Hill sulfide deposit at Middle Valley together with fluid inclusion and isotopic data confirm that temperatures below the sea floor were on the order of $350^{\circ}$ to $400^{\circ} \mathrm{C}$ (Butterfield et al., 1994b; Peter et al., 1994; Teagle and Alt, 2004), similar to end-member vent fluids on nearby sediment-free ridges.

The high $\mathrm{pH}$ and alkalinity of the vent fluids, combined with high $\mathrm{SiO}_{2}$ concentrations, results in the precipitation of abundant $\mathrm{Mg}$ silicates and carbonate during mixing with seawater, and chimneys composed only of anhydrite, barite, amorphous silica, smectite, or carbonate are common. Concentrations of ammonium in the vent fluids are several orders of magnitude higher than in typical mid-ocean ridge black smokers (e.g., 10-15 mmol at Guaymas basin compared to $<0.01 \mathrm{mmol}$ at $21^{\circ} \mathrm{N}$ EPR; Table A3), owing to the breakdown of N-bearing organic compounds in the sediments, and this produces a strong $\mathrm{pH}$ buffer via the reaction $\mathrm{NH}_{3}+\mathrm{H}^{+}=$ $\mathrm{NH}_{4}{ }^{+}$. The fluids are reduced by reaction with organic carbon and oxidation of $\mathrm{CH}_{4}$ produced by bacteria in the sediment (e.g., $\mathrm{C}_{\text {org }}+2 \mathrm{H}_{2} \mathrm{O}=\mathrm{CO}_{2}+2 \mathrm{H}_{2}$ and $\mathrm{CH}_{4}+2 \mathrm{H}_{2} \mathrm{O}=\mathrm{CO}_{2}+$ $4 \mathrm{H}_{2}$ ), and products of the thermal degradation of organic matter, including liquid petroleum and solid bitumens, are commonly preserved in the hydrothermal precipitates (Peter et al., 1990, 1991). Higher hydrocarbons (e.g., C1-C6) are also present in the vent fluids (Simoneit and Gize, 2000). Low $\delta^{13} \mathrm{C}_{\mathrm{CH}_{4}}$ values ( -43 to $-51 \%$ ) are common in the vent fluids (Table A4), even where relatively small amounts of organic matter are involved (e.g., Lilley at al., 1993). Methanogenic carbonates, which are locally abundant in the sediments surrounding the vents, also typically have very low $\delta^{13} \mathrm{C}_{\mathrm{CO}_{2}}$ values (Goodfellow and Zierenberg, 1999). A wide range of $\delta^{34} \mathrm{~S}$ values is observed (Fig. 7), indicating the action of bacteria and a larger contribution of seawater sulfate reduction than in basalt-dominated systems (Böhlke and Shanks, 1994; Zierenberg, 1994).

Basaltic ${ }^{87} \mathrm{Sr} /{ }^{86} \mathrm{Sr}$ and $\mathrm{Pb}$ isotope ratios and high ${ }^{3} \mathrm{He}$ concentrations confirm that the hydrothermal fluids at sedimentcovered ridges have equilibrated with basalt in the basement before reacting with the sediments (Goodfellow and Zierenberg, 1999; Bjerkgard et al., 2000). However, significant continent-derived $\mathrm{Pb}$ and $\mathrm{Sr}$ are evident in the hydrothermal precipitates in the Guaymas basin and at the Escanaba trough (Chen et al., 1986; LeHuray et al., 1988; Zierenberg et al., 1993). Continental terrigenous material also appears to have contributed to unusually high concentrations of such elements as $\mathrm{As}, \mathrm{Sb}, \mathrm{Hg}$, and $\mathrm{Sn}$ in some deposits and correspondingly complex mineral assemblages, including arsenopyrite, loellingite, stannite, tetrahedrite, and other $\mathrm{Pb}-\mathrm{As}$-Sb sulfosalts (e.g., the Escanaba trough: Koski et al., 1988; Zierenberg et al., 1993). Gold contents of sulfide deposits in sedimented rifts are typically low (e.g., <0.2 ppm Au at the Guaymas basin), reflecting the strongly reduced conditions (Hannington et al., 1991a). However, copper-rich sulfides from the Escanaba trough contain up to $10 \mathrm{ppm} \mathrm{Au}$, with an average of $1.5 \mathrm{ppm} \mathrm{Au}$, and might be explained by an enriched source in the underlying sediments.

Similar vent-fluid compositions are found in sedimented back-arc basins. Vent fluids in the Okinawa trough, have $\mathrm{NH}_{4}{ }^{+}$concentrations of up to $4.9 \mathrm{mmol}$, pH of 5.8, and low $\mathrm{CH}_{4}$ carbon isotope values (Tables A3, A4). These fluids are also precipitating locally abundant calcite, dolomite, and manganiferous carbonate (e.g., at Iheya Ridge), similar to the vents in the Guaymas basin. However, the fluids are less reduced and have notable concentrations of magmatic gases (Sakai et al., 1990).

The metalliferous brines of the Red Sea are unique in the present record of sea-floor hydrothermal systems. No other examples of high-temperature vent fluids that are more dense than seawater have been found (e.g., Scott, 1997). The brines originate from the dissolution of Miocene evaporite and react with a number of different rocks, including basalt and marine shale; the metals are mainly leached from the volcanic basement (Zierenberg and Shanks, 1986; Anschutz and Blanc, 1995; Anschutz et al., 1995). The lower brine in the Atlantis II Deep is nearly saturated with $\mathrm{NaCl}(25$ wt $\% \mathrm{NaCl})$ and strongly enriched in alkalies, but it is depleted in $\mathrm{Mg}$ and $\mathrm{SO}_{4}$, similar to mid-ocean ridge fluids. The high salinity and low $\mathrm{pH}$ (5.5) permit very high concentrations of metals in the brine pool, despite a temperature of only $60^{\circ} \mathrm{C}(80 \mathrm{ppm} \mathrm{Fe}$, 80 ppm Mn, 3 ppm Zn, 0.2 ppm Pb, and 0.02 ppm Cu: Pottorf and Barnes, 1983; Hartmann, 1985; Scholten et al., 2000). Estimates based on heat and salt balances indicate that the temperatures of the source fluids are between $195^{\circ}$ and $435^{\circ} \mathrm{C}$ (Ramboz and Danis, 1990; Anschutz and Blanc, 1996). 
This is supported by fluid inclusions in anhydrite, indicating a maximum temperature of $390^{\circ} \mathrm{C}$ (Oudin et al., 1984; Ramboz et al., 1988) and by the presence of pyrite-pyrrhotiteisocubanite with exsolved chalcopyrite in veins in the sediment (Pottorf and Barnes, 1983). However, the high-temperature fluid has not been sampled, and its composition is not known.

\section{Fluids in volcanic arcs and back-arc basins}

The major controls on vent fluid compositions in arc and back-arc settings are the same as those at mid-ocean ridges, but there is evidence that magmatic volatiles supply a number of components, including metals, to the hydrothermal fluids. End-member fluids commonly have higher concentrations of $\mathrm{K}$ and other alkali elements, reflecting the composition of the volcanic rocks (Table A3), and they tend to be more oxidized because of the lower abundance of $\mathrm{FeO}$-bearing minerals. The felsic rocks typical of arc settings are also a source of trace elements such as $\mathrm{Pb}, \mathrm{As}, \mathrm{Sb}$, and $\mathrm{Ba}$ (e.g., Stanton, 1994). Lead isotopes indicate that these elements are enriched in the lavas via contributions from the subducting slab (e.g., Fouquet and Marcoux, 1995). Even where basalt and andesite are the dominant rock types (e.g., Mariana trough, central Manus basin, North Fiji basin, Lau basin) the massive sulfide deposits commonly have higher concentrations of $\mathrm{Pb}$ and $\mathrm{Ba}$ than in mid-ocean ridge settings (Fig. 4, Table A2). In continental margin settings, such as in the Okinawa trough, the sulfide deposits have very low $\mathrm{Fe}$ contents and include many complex sulfosalts of $\mathrm{Pb}, \mathrm{Ag}, \mathrm{As}, \mathrm{Sb}$, and $\mathrm{Hg}$ (Halbach et al., 1993; Ishibashi and Urabe, 1995; Nakashima et al., 1995). Deposits on the volcanic arcs and in immature back-arc rifts also commonly have high concentrations of gold, whereas sulfide deposits at mature back-arc spreading centers have gold concentrations that are similar to those of mid-ocean ridge black smokers (Table A2). However, these differences do not appear to reflect differences in the gold contents of the source rocks (Herzig and Hannington, 1995) and may simply reflect the oxidation state of the fluids (e.g., Herzig et al., 1993). The role of magmatic volatiles in the enrichment of gold remains uncertain, but the presence of isotopically distinct fluids in some anomalously gold-rich systems provides positive evidence for a direct magmatic contribution (see below). Recent findings of $\mathrm{CO}_{2}$-rich inclusions in andesite from the eastern Manus basin containing high concentrations of $\mathrm{Cu}, \mathrm{Fe}$, and $\mathrm{Zn}$ chlorides support the suggestion that other metals also may be contributed directly from the magma (Yang and Scott, 1996, 2002; Kamenetsky et al., 2001).

$\mathrm{CO}_{2}$ concentrations are significantly higher in vent fluids at arc volcanoes than on the mid-ocean ridges $(40-260 \mathrm{mmol} / \mathrm{kg}$ vs. 5-15 mmol/kg: Sakai et al., 1990; Ishibashi et al., 1994; Tsunogai et al., 1994; Table A3). Unusual $\mathrm{pH}$ and $\mathrm{Al}$ anomalies in hydrothermal plumes also have been found and are considered to reflect volcanic degassing of $\mathrm{CO}_{2}$ and $\mathrm{SO}_{2}$ (Gamo et al., 1993, 1997; Resing and Sansone, 1996). Limited oxygen and hydrogen isotope data also indicate direct contributions of magmatic water in some arc and back-arc hydrothermal systems. Of particular significance are the unusually low $\delta \mathrm{D}$ values (to $-8.1 \%$ ) of $\mathrm{H}_{2} \mathrm{O}$ in vent fluids from the DESMOS cauldron (Gamo et al., 1997), which suggest a magmatic water component in the fluids similar to that indicated for some Kuroko deposits (Marumo and Hattori, 1999).

Sulfide $\delta^{34} \mathrm{~S}$ values for arc and back-arc hydrothermal systems are typically higher than in mid-ocean ridge black smokers, reflecting the higher $\delta^{34} \mathrm{~S}$ of arc lavas $\left(\delta^{34} \mathrm{~S}=4-10 \%\right.$ vs. $\delta^{34} \mathrm{~S}=0.1 \pm 0.5 \%$ in MORB: Ueda and Sakai, 1984; Alt et al., 1993). The higher $\delta^{34} S$ values are mainly attributed to subducted seawater sulfur that is recycled through arc magmatism. However, anomalously low $\delta^{34} \mathrm{~S}$ values also have been found (Fig. 7) and are attributed to the input of volcanic $\mathrm{SO}_{2}$ in the hydrothermal fluids (Herzig et al., 1998; Gemmell et al., 1999; Gena et al., 2001; de Ronde et al., 2005). Widespread sulfur-rich fumaroles in submarine arc and back-arc settings provide further evidence of direct venting of volcanic-derived sulfur gases. Significant deposits of elemental sulfur, sulfur-cemented hyaloclastite and volcanic breccias, sulfur-impregnated muds and tuffaceous sediment, and intensely altered lavas with sulfur-filled amygdules have been documented on active submarine arc and back-arc volcanoes, at water depths from 2,000 to $<100 \mathrm{~m}$ and at vent temperatures ranging from $250^{\circ}$ to $<100^{\circ} \mathrm{C}$ (cf. Hannington et al., 1999). Abundant elemental sulfur also is found in hydrothermal plumes. Along the Kermadec arc, sulfur concentrations in the plumes are up to 40 times higher than in typical midocean ridge plumes and correlate with low $\mathrm{pH}$ values (de Ronde et al., 2001; Massoth et al., 2003). Comparisons with $\mathrm{SO}_{2}$ emissions from subaerial volcanoes (e.g., Wallace, 2003) suggest that submarine arc volcanoes are likely discharging substantial quantities of sulfur into the oceans at a global scale.

The acidity produced by the condensation of reactive volcanic gases causes intense alteration of the volcanic rocks, and $\mathrm{Mg}$ and other cations that are normally depleted in black smoker vents are locally stripped from the rocks and released into the acidic hydrothermal fluids. In the DESMOS cauldron the vent fluids have a $\mathrm{pH}$ of 2.1 and higher $\mathrm{SO}_{4}$ concentrations than background seawater (Table A3). These data, combined with the very low $\delta^{34} \mathrm{~S}$ and $\delta \mathrm{D}_{\mathrm{H}_{2} \mathrm{O}}$ values mentioned above are compelling evidence that this is a submarine magmatic hydrothermal system. Similar low $\mathrm{pH}$ fluids have been sampled in the southern Lau basin, near the propagating tip of the back-arc rift (Hine Hina vent field), and they are associated with intensely altered andesite, sulfur-cemented volcaniclastic breccias, and stockwork veining with advanced argillic alteration (quartz, kaolinite, pyrophyllite, and minor alunite: Fouquet et al., 1993; Herzig et al., 1993). The isotopic compositions of coexisting sulfides and sulfate minerals (including alunite) indicate direct input of magmatic $\mathrm{SO}_{2}$ in the hydrothermal fluids (Herzig et al., 1998). Similar alunitebearing alteration has been documented at DESMOS, at Conical seamount in the Tabar-Feni arc, and in the Brothers caldera on the Kermadec arc (Gena et al., 2001; Petersen et al., 2002; Gemmell et al., 2004; de Ronde et al., 2005). At several vent sites, high-sulfidation-state sulfide assemblages (e.g., bornite + pyrite and tennantite + enargite) also have been noted, including at Palinuro seamount in the Tyrrhenian Sea (Minniti and Bonavia, 1984; Dekov and Savelli, 2004), in the eastern Manus basin (Gena et al., 2001; Moss and Scott, 2001; Binns et al., 2002) and on the Brothers volcano in the Kermadec arc (de Ronde et al., 2005). These minerals are 
indicative of oxidized, sulfur-rich (and possibly chloride-rich) fluids, similar to those associated with high-sulfidation $\mathrm{Cu}-\mathrm{Au}$ deposits (Arribas, 1995; Sillitoe et al., 1996).

Notable coenrichment of $\mathrm{Cu}$ and $\mathrm{Au}$ has been found in a number of black smoker chimneys from volcanic arcs (e.g., 10-20 ppm Au in Cu-rich chimneys from Suiyo seamount on the Izu-Bonin arc and in the deposits in the eastern Manus basin: Tsunogai et al., 1994; Watanabe and Kajimura, 1994; Moss and Scott, 2001). The concentrations of gold are orders of magnitude higher than in similarly Cu-rich black smokers from the mid-ocean ridges, suggesting that gold concentrations in the vent fluids may be much higher. Certain other trace elements, such as $\mathrm{Bi}$ and $\mathrm{Te}$, are closely associated with gold in these Cu-rich chimneys and reach concentrations of up to $200 \mathrm{ppm}$ Bi and $150 \mathrm{ppm}$ Te (Watanabe and Kajimura 1994; Moss and Scott 2001). Discrete Bi telluride minerals also have been documented at Palinuro seamount (Dekov and Savelli, 2004). The $\mathrm{Cu}-\mathrm{Au}-\mathrm{Bi}-\mathrm{Te}$ association may reflect a felsic magmatic source for the metals, similar to that observed in subaerial magmatic hydrothermal systems. In a submarine setting, a magmatic vapor plume of the type at White Island (e.g., combined fluxes of 110,000 kg/yr Cu, $2190 \mathrm{~kg} / \mathrm{yr} \mathrm{Bi}$, and $>36 \mathrm{~kg} / \mathrm{yr}$ Au from passive degassing and quiescent eruptions: Le Cloarec et al. 1992; Hedenquist et al. 1993) could deliver a significant amount of $\mathrm{Cu}$ and $\mathrm{Au}$ to the sea floor.

\section{Duration of Hydrothermal Activity, Mass Accumulation Rates, and Sizes of Deposits}

Of the more than 100 sites of high-temperature hydrothermal venting considered in this review, 30 are host to large sulfide deposits (Hannington et al., 1995; Fouquet, 1997). However, many are incompletely surveyed, and reported dimensions commonly include large areas of discontinuous sulfide outcrop or barren substrate between vents. Data from drilling by ODP have provided some details on the internal structures of the largest deposits (e.g., Humphris et al., 1995), but only two deposits have been drilled adequately to allow an estimate of total tonnage. The large TAG mound on the MidAtlantic Ridge, which measures $200 \mathrm{~m}$ in diameter and $45 \mathrm{~m}$ in height, contains $2.7 \mathrm{Mt}$ of massive sulfide averaging $2 \mathrm{wt}$ percent $\mathrm{Cu}$ and $1.2 \mathrm{Mt}$ of stockwork at 1 wt percent $\mathrm{Cu}$ (based on 17 holes drilled to a maximum depth of $125 \mathrm{~m}$ during ODP Leg 158: Hannington et al., 1998). This is comparable to many Cyprus-type massive sulfide deposits on land. Four deep drill holes that penetrated the Bent Hill and ODP mounds at Middle Valley (ODP Legs 139 and 169) indicate a combined tonnage of between 10 and $15 \mathrm{Mt}$ (Fouquet et al., 1998; Zierenberg et al., 1998), making them the largest accumulation of polymetallic sulfides on the sea floor after the Red Sea. Several other large deposits on the mid-ocean ridges are on the order of 100,000 t up to 1 Mt each (Lucky Strike, Snakepit, Logatchev, $13^{\circ} \mathrm{N}$ EPR, and the Galapagos rift). In the back-arc rifts of the western Pacific, the largest deposits are in the Manus basin, the North Fiji basin, the southern Lau basin, and the Okinawa trough and are similar in size to some large deposits on the mid-ocean ridges.

The largest vent complexes on the mid-ocean ridges are active intermittently for periods lasting $10^{3}$ to $10^{5}$ years. The presently active TAG mound sits on 100,000- to 200,000-yearold crust, and high-temperature venting began at least 20,000 to 50,000 years ago (based on ${ }^{234} \mathrm{U} / 230 \mathrm{Th}$ measurements: Lalou et al., 1990, 1998). The accumulation of sulfides in the TAG mound over this time has occurred during several transient phases of activity lasting up to several thousand years (Lalou et al., 1995, 1998; Humphris and Tivey, 2000). Based on the age data and the size of the mound (2.7 Mt of massive sulfide), Hannington et al. (1998) calculated a growth rate for the main massive sulfide lens of about 500 to $1,000 \mathrm{t} / \mathrm{yr}$, although higher rates of accumulation have been calculated based on the amount of metal that is currently being delivered to the sea floor by high-temperature fluids (e.g., Humphris and Cann, 2000). Like TAG, the Middle Valley deposits are situated on crust that is at least 300,000 years old, and the hydrothermal system is estimated to be 125,000 years old (Davis and Villinger, 1992). In both cases, the protracted history of hydrothermal venting is interpreted to be a result of deep-seated magmatic activity followed by long periods of cooling and release of heat from depth. This contrasts with the heat and fluid flow associated with high-temperature black smoker vents on the fast-spreading ridges, which are driven mainly by shallow dikelike intrusions. The high rate of heat removal by individual black smokers ensures that venting associated with shallow diking events on fast-spreading ridges is relatively short lived (e.g., Lowell et al., 1995). This is confirmed by isotopic dating, which indicates that hydrothermal discharge at individual black smokers lasts only 10 to 100 years (based on ${ }^{228} \mathrm{Th} /{ }^{228} \mathrm{Ra}$ and ${ }^{210} \mathrm{~Pb}$ : e.g., Kadko et al., 1985; Stakes and Moore, 1991; Koski et al., 1994).

The metalliferous sediments of the Atlantis II Deep in the Red Sea represent the largest accumulation of metals associated with hydrothermal venting on the sea floor. The total tonnage of metalliferous sediment is estimated to be $696 \mathrm{Mt}$, and systematic sampling in 627 cores has proven a resource of 91.7 Mt, on a dry, salt-free basis, with grades of $2.06 \mathrm{wt}$ percent $\mathrm{Zn}, 0.46$ wt percent $\mathrm{Cu}, 58.5 \mathrm{~g} / \mathrm{t} \mathrm{Co}, 40.95 \mathrm{~g} / \mathrm{t} \mathrm{Ag}$, and $0.51 \mathrm{~g} / \mathrm{t} \mathrm{Au}$ (Guney et al., 1988). The total metal content is 27 Mt Fe, $1.89 \mathrm{Mt} \mathrm{Zn,} \mathrm{425,000} \mathrm{t} \mathrm{Cu,} \mathrm{5,369} \mathrm{t} \mathrm{Co,} \mathrm{3,750} \mathrm{t} \mathrm{Ag,} \mathrm{and}$ $47 \mathrm{t} \mathrm{Au}$. Although the oldest sediments are between 25,000 and 28,000 years old, the deposition of the lowermost sulfidic zone began about 15,000 years ago, when the stable brine pool was established (Bäcker and Richter, 1973; Shanks and Bischoff, 1980). Assuming that the present resource (e.g., $1.89 \mathrm{Mt} \mathrm{Zn}$ ) has accumulated over the last 15,000 years, the average metal accumulation rate has been $126 \mathrm{t} \mathrm{Zn/yr.} \mathrm{This} \mathrm{is}$ equivalent to 100 percent efficiency of deposition from a brine having a $\mathrm{Zn}$ concentration of about $5 \mathrm{ppm}$ at the estimated influx rate of $670 \mathrm{~kg} / \mathrm{s}$ (Anschutz and Blanc, 1996) and similar to the combined flux of metal from several large midocean ridge black smoker vent fields.

\section{Summary and Concluding Remarks}

The largest sulfide deposits on the sea floor occur in highly fractured crust at intermediate- and slow-spreading centers, where this is little or no evidence of recent volcanic eruptions. Deeply penetrating faults in these settings allow circulation of seawater to considerable depths and, in some cases, at some distance off axis. Active extension maintains the fluid pathways necessary for large-scale hydrothermal convection and supports the necessary permeability to extract heat and metals from a large volume of rock. The strongly rock buffered 
chemistry of the end-member fluids indicates that fluid pathways expand with time, driven downward by cracking fronts that expose fresh rock to hydrothermal leaching. A large and deep heat source that is episodically replenished is considered essential for the formation of the largest deposits. The associated structures also must be large enough to accommodate extension for long periods without disrupting large-scale hydrothermal systems contained within the faults. Oblique or asymmetric spreading, as in transtensional basins or extensional transform zones (Taylor et al., 1994), are particularly favorable for such large-scale faulting and long-lived hydrothermal upflow. Where magma is intruded at shallow crustal levels or high in a volcano, hydrothermal activity is shallow, vigorous, and short lived, and therefore less likely to produce a large deposit. Conditions for sulfide accumulation are enhanced in sediment-filled basins, where large hydrothermal systems are associated with sill-sediment complexes and massive sulfides are deposited by subsea-floor replacement within the sediments overlying a permeable volcanic basement.

Mantle plumes can be a trigger for enhanced crustal melting and magma supply and are responsible for particularly vigorous hydrothermal activity at ridge-hot spot intersections. Plumes also may have initiated major rifting events in continental lithosphere (e.g., Afar rift). However, hot-spot volcanoes away from ridges appear to host limited high-temperature hydrothermal venting, despite their importance in terms of the overall magmatic budget of the oceans. Interactions between mantle plumes and submarine volcanic arcs, which have been proposed for some ancient VMS-hosting terranes, have not been documented in the present-day oceans, although there is evidence for contributions from a plume source in some magmas in the North Fiji basin and in the northern Lau basin.

Deposits forming in mature intraoceanic back-arc basins closely resemble those on the mid-ocean ridges, reflecting the similar structure, magma supply, and melt compositions of the spreading centers. However, like Cyprus-type massive sulfide deposits, hydrothermal systems in these settings have a low potential for preservation owing to eventual subduction of the back-arc spreading centers. By analogy with ancient VMS deposits, the most productive sea-floor hydrothermal systems are likely to be found in extensional arc environments, where rifting of the arc crust provides the necessary heat for the generation of abundant deep crustal melts and large-scale hydrothermal convection. Volcanic rifted margins, which are characterized by high crustal heat flow, kilometerscale pre- and synvolcanic extensional faulting, and a thick sedimentary cover are the most favorable settings for large deposits. The sedimented rifts in epicontinental or continental margin arc environments are likely modern analogs of settings that host major VMS districts, such as Bathurst, New Brunswick, and the Iberian Pyrite Belt. Intracontinental back-arc rifts receive a large sediment load from the adjacent continental shelf, and the sediment has an insulating effect, preserving the high heat flow associated with rifting of the thick continental crust and also enhancing the preservation of contained sulfide deposits. Initial rifting of arc crust or continental crust also can lead to the development of large calderalike sea-floor depressions, such as the DESMOS cauldron in the eastern Manus basin and the Izena cauldron in the Okinawa trough. These structures have many similarities to the calderalike depressions that host some large VMS systems in the geologic record (e.g., Franklin et al., 2005). Unlike the small calderas on many arc stratovolcanoes, which are products of caldera-forming eruptions, rift-related "cauldrons" appear to be mainly structural features that are floored by andesite and basalt and likely underlain by large subvolcanic intrusions.

Opposing subduction zones, oblique collisions, and microplate tectonics that characterize the western Pacific today also were likely important for the formation and preservation of VMS deposits in many ancient terranes. In such complex microplate mosaics, rapid changes in stress regimes (e.g., from compressional to tensional and back to compressional) are common, and diverse sea-floor hydrothermal systems can occupy different volcanic and tectonic positions in close proximity. In the southern Havre trough of New Zealand, for example, a fore-arc graben, a volcanic arc, and an active backarc rift, as well as the transition from oceanic to continental basement and dominantly submarine to subaerial hydrothermal systems, occur in the space of only a few tens of kilometers. Different magmatic suites, including both mid-ocean ridge basalt and typical arc lavas, are separated by as little as $15 \mathrm{~km}$ (Gamble and Wright, 1995). In the eastern Manus basin, distinctive $\mathrm{Cu}-\mathrm{Au}$-rich polymetallic massive sulfides are associated with calc-alkaline submarine volcanism on Pual Ridge, whereas epithermal-style gold mineralization is associated with alkaline volcanoes in the immediately adjacent New Ireland basin (e.g., Petersen et al., 2002).

Magmatic contributions to sea-floor hydrothermal fluids are likely significant in many arc-related systems. In most cases, mixing with reduced hydrothermal fluids in larger scale convective hydrothermal systems and dilution by seawater will cause the magmatic component to equilibrate at intermediate $\mathrm{pH}$ values and oxidation states prior to venting. However, an analogy with subaerial magmatic-hydrothermal systems is suggested in some environments (Sillitoe et al., 1996). Thus, a complete spectrum of fluid compositions and styles of mineralization may be found. Samples of apparent submarine porphyry-style mineralization have been recovered from a tonalite exposed by collapse of a volcano in the northern IzuBonin arc (Ishizuka et al., 2002), but there is no clear evidence of a relationship between sea-floor hydrothermal activity and submarine porphyry-copper mineralization. This is consistent with the observation that ancient VMS and porphyry $\mathrm{Cu}$ deposits are almost never found together (e.g., Sillitoe, 1980). However, in the geologic record, VMS deposits that might have formed above submarine porphyry systems may have been removed where the porphyry-style mineralization is now exposed. In some shallow submarine environments, the emergence of volcanic arcs as a result of tectonic uplift during collision, or submergence of the volcanoes due to subsidence during arc rifting, also may lead to overprinting of dramatically different styles of mineralization.

Further exploration is required to evaluate the importance of volcanoes at the arc front as a setting for VMS deposits. Compared to arc-related rifts, the small, shallow magma chambers beneath the summit calderas of arc stratovolcanoes are expected to result in smaller hydrothermal circulation cells and correspondingly smaller but potentially high-grade 
deposits. Shallow water depths and lower confining pressures at the summits of arc volcanoes also result in lower venting temperatures, owing to subsea-floor boiling. This may lead to vertically extensive stockwork mineralization rather than the development of large sea-floor massive sulfide deposits. Frequent disruptions of the hydrothermal systems by explosive eruptions also are likely, as indicated by the abundant pyroclastic deposits that occur in the calderas of even the deepest submarine arc volcanoes (Fiske et al., 1998, 2001).

The many different volcanic and tectonic settings of convergent margins along the western Pacific are viewed as important modern analogs for the structure and metallogenic evolution of ancient VMS districts, including in some of the oldest granite-greenstone terranes. The major ore deposits of the southern Abitibi greenstone belt, for example, were formed within a span of less than 50 m.y., resulting from successive arc rifting, back-arc basin development, and ending with exhumation of the adjoining accretionary complexes along major arc-parallel crustal-scale faults (e.g., Poulsen et al., 1992). Active marginal basins of similar size and representing similar stages of this evolution are recognized in the complex microplate mosaics throughout the western Pacific today (e.g., the eastern Manus basin). However, the Late Archean was almost certainly characterized by faster rates of crustal accretion, enhanced volcanism, and higher heat flow, possibly with shallower water depths, higher ocean temperatures, and seawater chemistry that was predominantly mantle buffered (e.g., Groves and Barley, 1994). Abundant maficultramafic magmatism in the Archean also might have created conditions for widespread low-temperature venting associated with serpentinization reactions, similar to those observed on present-day slow-spreading ridges. These differences likely had a profound influence on sea-floor hydrothermal activity in the Archean ocean (e.g., Ohmoto, 1996).

Despite more than two decades of intensive research, there is a continuing lack of data concerning the number distribution, size, and composition of sea-floor polymetallic sulfide deposits in some environments. Certain tectonic settings that are well-endowed with mineral deposits in the geologic record (e.g., rifted continental margins) have yet to be fully explored on the ocean floor. Other deposit types might be expected in submarine shelf environments (e.g., clastic sediment-hosted and carbonate-hosted $\mathrm{Pb}-\mathrm{Zn}-\mathrm{Ag}$ deposits) but have not been found. These are obvious targets for future exploration in the oceans. In addition to polymetallic sulfide deposits, other vast resources of metals are known on the ocean floor. Nearly 34 billion tons (Bt) of manganese nodules occur in the Pacific high-grade area, containing 7.5 Bt of $\mathrm{Mn}$, $340 \mathrm{Mt}$ of Ni, $265 \mathrm{Mt}$ of $\mathrm{Cu}$, and $78 \mathrm{Mt}$ of Co (Morgan, 2000; Rona, 2003). However, it is still premature to judge the potential future economic significance of these and other deepsea mineral resources (Glasby, 2000). It may be decades before commercial exploitation of these deposits is realized. In the meantime, they will continue to be an important natural laboratory for the study of ore-forming processes in the submarine environment.

\section{Acknowledgments}

Many of the observations presented in this review are drawn from the personal experiences of the authors during 35 research cruises. These expeditions were made possible by collaboration with numerous partner institutions. In particular, we wish to thank Peter Herzig and Peter Stoffers, who led many of the projects. This paper has benefited greatly from extensive discussions and interaction at sea with close colleagues and friends, including Steve Scott, Jim Franklin, Ian Jonasson, Bob Embley, Garry Massoth, Ed Baker, Ulrich Schwarz-Schampera, Thomas Khun, Susan Humphris, Yves Fouquet, John Delaney, Meg Tivey, Bruce Gemmell, Ray Binns, and Ian Wright. This work was supported by Natural Resources Canada (NRCan), the German Federal Ministry of Education and Research (BMBF), the German Research Foundation (DFG), the Alexander von Humboldt Foundation, IFM-Geomar and University of Kiel, the Bundesanstalt für Geowissenschaften und Rohstoffe (BGR), the New Zealand Foundation for Research, Science and Technology (FRST), and the National Oceanic and Atmospheric Administration Vents Program. MDH and SP gratefully acknowledge the support of the Geological Survey of Canada and the Freiberg University of Mining and Technology, Germany, during the preparation of this manuscript. Helpful reviews by Jeff Alt, Joe Cann, Jeremy Richards, and Jeffrey Hedenquist greatly improved earlier versions of this paper.

\section{REFERENCES}

Allen, D.A., and Seyfried, W.E., Jr., 2003, Compositional controls on vent fluids from ultramafic-hosted hydrothermal systems at mid-ocean ridges: An experimental study at $400^{\circ} \mathrm{C}, 500$ bars: Geochimica et Cosmochimica Acta, v. 67 , p. $1531-1542$.

2004 , Serpentinization and heat generation: Constraints from Lost City and Rainbow hydrothermal systems: Geochimica et Cosmochimica Acta, v. 68 , p. $1347-1354$

Alt, J.C., and Shanks, W.C., III, 2003, Serpentinization of abyssal peridotites from the MARK area, Mid-Atlantic Ridge: Sulfur geochemistry and reaction modeling: Geochimica et Cosmochimica Acta, v. 67, p. 641-653.

Alt, J.C., Shanks, W.C., III, and Jackson, M.C., 1993, Cycling of sulfur in subduction zones: The geochemistry of sulfur in the Mariana island arc and back-arc trough: Earth and Planetary Science Letters, v. 119, p. 477-494.

Ames, D.E., Franklin, J.M., and Hannington, M.D., 1993, Mineralogy and geochemistry of active and inactive chimneys and massive sulfide, Middle Valley, northern Juan De Fuca Ridge: An evolving hydrothermal system: Canadian Mineralogist, v. 31, p. 997-1024.

Anschutz, P., and Blanc, G., 1995, Chemical mass balances in metalliferous deposits from the Atlantis II Deep, Red Sea: Geochimica et Cosmochimica Acta, v. 59 , p. $4205-4218$

1996, Heat and salt fluxes in the Atlantis II Deep (Red Sea): Earth and Planetary Science Letters, v. 142, p. 147-159.

Anschutz, P., Blanc, G., and Stille, P., 1995, Origin of fluids and the evolution of the Atlantis II Deep hydrothermal system, Red Sea: Strontium isotope study: Geochimica et Cosmochimica Acta, v. 59, p. 4799-4808.

Arculus, R.J., 1999, Origin of the continental crust: Journal and Proceedings of the Royal Society of New South Wales, v. 132, p. 83-110.

Arribas, A., Jr., 1995, Characteristics of high-sulfidation epithermal deposits, and their relation to magmatic fluid: Mineralogical Association of Canada Short Course Series 23, p. 419-454.

Auclair, G., Fouquet, Y., and Bohn, M., 1987, Distribution of selenium in high-temperature hydrothermal sulfide deposits at $13^{\circ} \mathrm{N}$, East Pacific Rise: Canadian Mineralogist, v. 25, p. 577-588.

Auzende, J.-M., and Urabe, T., 1994, The STARMER French-Japanese joint project, 1987-1992: Marine Geology, v. 116, p. 1-3.

Auzende, J., Cannat, M., Gente, P., Henriet, J.P., Juteau, T., Karson, J., and Lagabrielle, Y., 1994, Observations of section of oceanic crust and mantle outcropping on the southern wall of the Kane FZ (N. Atlantic): Terra Nova, v. 6 , p. $143-148$.

Auzende, J.M., Pelletier, B., and Eissen, I.-P., 1995, The North Fiji Basin geology, structure, and geodynamic evolution, in Taylor, B., ed., Backarc basins: Tectonics and magmatism: New York, Plenum Press, p. 139-175. 
Auzende, J.-M., Ishibashi, J.-I., Beaudoin, Y., Charlou, J.-L., Donval, J.-P., Fouquet, Y., Ildefonse, B., Kimura, H., Nishio, Y., Radford-Knoery, J., and Ruellan, E., 2000, Extensive magmatic and hydrothermal activity documented in Manus Basin: EOS, v. 81, p. 449-453.

Bcker, H., and Richter, H., 1973, Die rezente hydrothermal-sedimentare lagerstatte Atlantis II-Tief im Roten Meer: Geologisches Rundschau, v. 3, p. $697-741$

Baker, E.T., and German, C.R., 2004, On the global distribution of hydrothermal vent sites: Geophysical Monograph 148, p. 1-18.

Baker, E.T., Massoth, G.J., Walker, S.L., and Embley, R.W., 1993, A method for quantitatively estimating diffuse and discrete hydrothermal discharge: Earth and Planetary Science Letters, v. 118, p. 235-249.

Baker, E.T., German, C.R., and Elderfield, H., 1995, Hydrothermal plumes over spreading center axes: global distribution and geological inferences: Geophysical Monograph 91, p. 47-71.

Baker, E.T., Chen, Y.J., and Phipps Morgan, J., 1996, The relationship between near-axis hydrothermal cooling and the spreading rate of mid-ocean ridges: Earth and Planetary Science Letters, v. 142, p. 137-145.

Baker, E.T., Feely, R.A., de Ronde, C.E.J., Massoth, G.J., and Wright, I.C., 2003, Submarine hydrothermal venting on the southern Kermadec volcanic arc front (offshore New Zealand): Location and extent of particle plume signatures: Geological Society of London Special Publication 219, p. $141-161$.

Barrie, C.T., and Hannington, M.D., 1999, Classification of volcanic-associated massive sulfide deposits based on host-rock composition: Reviews in Economic Geology, v. 8, p. 1-11.

Batiza, R., and White, J.D.L., 2000, Submarine lavas and hyaloclastite, in Sigurdsson, H., Houghton, B.F., McNutt, S.R., Rymer, H., Stix, J., and Ballard, R.D., eds., Encyclopedia of volcanoes: San Diego, Academic Press, p. 361-381.

Beccaluva, L., Gabbianelli, G., Lucchini, F., Rossi, P.L., and Savelli, C., 1985, Petrology, and K/Ar ages of volcanics dredged from the Aeolian seamounts: Implications for geodynamic evolution of the southern Tyrrhenian basin: Earth and Planetary Science Letters, v. 74, p. 187-208.

Becker, K., and Von Herzen, R.P., 1996, Pre-drilling observations of conductive heat flow at the TAG active mound using Alvin: Proceedings of the Ocean Drilling Program, Initial Reports, v. 158, p. 23-29.

Bemis, K.G., von Herzen, R.P., and Mottl, M.J., 1993, Geothermal heat flux from hydrothermal plumes on the Juan de Fuca Ridge: Journal of Geophysical Research, v. 98, p. 6351-6365.

Benes, V., Scott, S.D., and Binns, R.A., 1994, Tectonics of rift propagation into a continental margin: Western Woodlark basin, Papua New Guinea: Journal of Geophysical Research, v. 99, p. 4439-4455.

Berndt, M.E., Allen, D.E., and Seyfried, W.E., Jr., 1996, Reduction of $\mathrm{CO}_{2}$ during serpentinization of olivine at $300^{\circ} \mathrm{C}$ and 500 bar: Geology, v. 24, p. $351-354$.

Bertine, K.K., and Keene, J.B., 1975, Submarine barite-opal rocks of hydrothermal origin: Science, v. 188, p. 150-152.

Binns, R.A., and Scott, S.D., 1993, Actively formingly polymetallic sulfide deposits in the eastern Manus backarc basin, Papua New Guinea: Economic GeOlOGY, v. 88, p. 2226-2236.

Binns R.A., Scott, S.D., Bogdanov, Y.A., Lisitzin, A.P., Gordeev, V.V., Gurvich, E.G., Finlayson, E.J., Boyd, T., Dotter, L.E., Wheller, G.E., and Muravyev, K.G., 1993, Hydrothermal oxide and gold-rich sulphate deposits of Franklin seamount, western Woodlark basin, Papua New Guinea: EcoNOMIC GEOLOGY, v. 88, p. 2122-2153.

Binns, R.A., Parr, J.M., Gemmell, J.B., Whitford, D.J., and Dean, J.A., 1997, Nature and source of precious metals in barite silica chimneys from Franklin Seamount, Woodlark Basin, Papua New Guinea: Marine Geology, v. 142 , p. $119-141$.

Binns, R.A., Barriga, F.J.S., and Miller, D.J., 2002, Anatomy of an active felsic-hosted hydrothermal system, eastern Manus Basin: Proceedings of the Ocean Drilling Program, Initial Reports, Summary, v. 193, p. 1-84.

Bischoff, J.L., and Pitzer, K.S., 1985, Phase relations and adiabats in boiling seafloor geothermal systems: Earth and Planetary Science Letters, v. 75, p. 327-338.

Bischoff, J.L., and Rosenbauer, R.J., 1983, A note on the chemistry of seawater in the range $350^{\circ}-500^{\circ} \mathrm{C}$ : Geochimica et Cosmochimica Acta, v. 47 , p. 139-144.

1984, The critical point and two-phase boundary of seawater, $200^{\circ}-500^{\circ} \mathrm{C}$ : Earth and Planetary Science Letters, v. 68 , p. $172-180$.

-1987, Phase separation in seafloor geothermal systems: An experimental study on the effects of metal transport: American Journal of Science, v. 287, p. $953-978$.
1988, Liquid-vapor relations in the critical region of the system $\mathrm{NaCl}-$ $\mathrm{H}_{2} \mathrm{O}$ from $380^{\circ} \mathrm{C}$ to $415^{\circ} \mathrm{C}$ : A refined determination of the critical point and two-phase boundary of seawater: Geochimica et Cosmochimica Acta, v. 52 , p. $2121-2126$

1989, Salinity variations in submarine hydrothermal systems by layered double-diffusive convection: Journal of Geology, v. 97, p. 613-623.

Bischoff, J.L., and Seyfried, W.E., 1978, Hydrothermal chemistry of seawater from $25^{\circ}$ to $350^{\circ} \mathrm{C}$ : American Journal of Science, v. 278 , p. 838-860.

Bischoff, J.L., Radtke, A.S., and Rosenbauer, R.J., 1981, Hydrothermal alteration of graywacke by brine and seawater: Roles of alteration and chloride complexing on metal solubilization at $200^{\circ}$ and $350^{\circ} \mathrm{C}$ : ECONOMIC GEOLOGY, v. 76, p. 659-676.

Bjerkgard, T., Cousens, B.L., and Franklin, J.M., 2000, The Middle Valley sulfide deposits, northern Juan de Fuca Ridge; Radiogenic isotope systematics: ECONOMIC GEOLOGY, v. 95, p. 1473-1488.

Blum, N., and Puchelt, H., 1991, Sedimentary-hosted polymetallic massive sulfide deposits of the Kebrit and Shaban Deeps, Red Sea: Mineralium Deposita, v. 26, p. 217-227.

Bogdanov, Y.A., Bortnikov, N.S., Vikentyev, I.V., Gurvich, E.G., and Sagalevich, A.M., 1997, A new type of modern mineral-forming systems: Black smokers of the hydrothermal field at $14^{\circ} 45^{\prime} \mathrm{N}$ latitude, Mid-Atlantic Ridge: Geology of Ore Deposits, v. 39, p. 68-90.

Bogdanov, Y.A., Bortnikov, N.S., Vikent'ev, I.V., Lein, A.Y., Gurvish, E.G., Sagalevich, A.M., Simonov, V.A., Ikorskii, S.V., Stavrova, O.O., and Apollonov, V.N., 2002, Mineralogical-geochemical peculiarities of hydrotherma sulfide ores and fluids in the Rainbow field associated with serpentinites, Mid-Atlantic Ridge ( $\left.36^{\circ} 14^{\prime} \mathrm{N}\right)$ : Geology of Ore Deposits, v. 44, p. 444-473. Böhlke, J.K., and Shanks, W.C., 1994, Stable isotope study of hydrotherma vents at Escanaba trough: Observed and calculated effects of sediment-seawater interaction: U.S. Geological Survey Bulletin 2022, p. 223-239.

Bonatti, E., Fisher, D.E., Joenssu, O., Rydell, H.S., and Beyth, M., 1972 , Iron-manganese-barium deposit from the Northern Afar rift, Ethiopia: ECONOMIC GEOLOGY, v. 67, p. 717-730.

Bortnikov, N.S., Fedorov, D.T., and Murav'ev, K.G., 1993, Mineral composition and conditions of the formation of sulfide edifices in the Lau basin (southwestern sector of the Pacific Ocean): Geology of Ore Deposits, v. 35, p. 476-488.

Bowers, T.S., Campbell, A.C., Measures, C.I., Spivack, A.J., and Edmond, J.M., 1988, Chemical controls on the composition of vent fluids at $13^{\circ}$ $11^{\circ} \mathrm{N}$ and $21^{\circ} \mathrm{N}$, East Pacific Rise: Journal of Geophysical Research, v. 93, p. $522-4536$.

Bowers, T.S., Von Damm, K.L., and Edmond, J.M., 1985, Chemical evolution of mid-ocean ridge hot springs: Geochimica et Cosmochimica Acta, v. 49 , p. 2239-2252.

Butterfield, D.A., 2000, Deep ocean hydrothermal vents, in Sigurdsson, H., Houghton, B.F., McNutt, S.R., Rymer, H., Stix, J., and Ballard, R.D., eds., Encyclopedia of volcanoes: San Diego, CA, Academic Press, p. 857-875.

Butterfield, D.A., and Massoth, G.J., 1994, Geochemistry of North Cleft segment vent fluids: Temporal changes in chlorinity and their possible relation to recent volcanism: Journal of Geophysical Research, v. 99, p. 4951-4968.

Butterfield, D.A., Massoth, G.J., McDuff, R.E., Lupton, J.E., and Lilley, M.D., 1990, Geochemistry of hydrothermal fluids from ASHES vent field, Juan de Fuca Ridge: Subseafloor boiling and subsequent fluid-rock interaction: Journal of Geophysical Research, v. 95, p. 12,895-12,921.

Butterfield, D.A., McDuff, R.E., Mottl, M.J., Lilley, M.D., Lupton, J.E., and Massoth, G.J., 1994a, Gradients in the composition of hydrothermal fluids from Endeavour Ridge vent field: Phase separation and brine loss: Journal of Geophysical Research, v. 99, p. 9561-9583.

Butterfield, D.A., McDuff, R.E., Franklin, J.M., and Wheat, C.G., 1994b, Geochemistry of hydrothermal vent fluids from Middle Valley, Juan de Fuca Ridge: Proceedings of the Ocean Drilling Program, Scientific Results, v. 139 , p. $395-410$

Butterfield, D.A., Jonasson, I.R., Massoth, G.J., Feely, R.A., Roe, K.K., Embley, R.E., Holden, J.F., McDuff, R.E., Lilley, M.D., and Delaney, J.R., 1997, Seafloor eruptions and evolution of hydrothermal fluid chemistry, in Cann, J.R., Elderfield, H., and Laughton, A., eds., Mid-ocean ridges: Dynamics of processes associated with creation of new ocean crust: Cambridge, Cambridge University Press, p. 153-170.

Campbell, A.C., Bowers, T.S., and Edmond, J.M., 1988, A time-series of vent fluid compositions from $21^{\circ} \mathrm{N}$ EPR $(1979,1981,1985)$, and the Guaymas Basin Gulf of California (1982, 1985): Journal of Geophysical Research, v. 93, p. $4537-4549$

Campbell, A.C., German, C.R., Palmer, M.R., and Edmond, J.M., 1994, Chemistry of hydrothermal fluids from the Escanaba trough, Gorda Ridge: U.S. Geological Survey Bulletin 2022, p. 201-222. 
Cannat, M., Mével, C., Maia, M., Deplus, C., Drand, C., Gente, P., Agrinier, P., Belarouchi, A., Dubuisson, G., Humler, E., and Reynolds, J., 1995, Thin crust, ultramafic exposures, and rugged faulting patterns at the Mid-Atlantic Ridge: Geology, v. 23, p. 49-52.

Carman, G.D., 2003, Geology, mineralization, and hydrothermal evolution of the Ladolam gold deposit, Lihir island, Papua New Guinea: Society of Economic Geologists Special Publication 10, p. 247-284.

Cathles, L.M., Guber, A.L., Lenagh, T.C., and Dudas, F.O., 1983, Kurokotype massive sulfide deposits of Japan; products of an aborted island-arc rift: ECONOMiC GEOLOGY MONOGRAPH 5, p. 96-114.

Charlou, J.L., Fouquet, Y.A., Bougault, H., Donval, J-P., Etoubleau, J., and Shipboard Party, 1998, Intense $\mathrm{CH}_{4}$ degassing generated by serpentinization of ultramafic rocks at the intersection of the $15^{\circ} 20^{\prime} \mathrm{N}$ fracture zone and the Mid-Atlantic Ridge: Geochimica et Cosmochimica Acta, v. 62, p. 2323-2333.

Charlou, J.L., Donval, J.P., Fouquet, Y., Jean-Baptiste, P., and Holm, N., 2002, Geochemistry of high $\mathrm{H}_{2}$ and $\mathrm{CH}_{4}$ vent fluids issuing from ultramafic rocks at the Rainbow hydrothermal field ( $\left.36^{\circ} 14^{\prime} \mathrm{N}, \mathrm{MAR}\right)$ : Chemical Geology, v. 191, p. 345-359.

Cheminée, J.L., Stoffers, P., McMurtry, G., Richnow, H., Puteanus, D., and Sedwick, P., 1991, Gas-rich submarine exhalations during the 1989 eruption of Macdonald Seamount: Earth and Planetary Science Letters, v. 107, p. $318-327$

Chen, J.H., Wasserburg, G.J., Von Damm, K.L. and Edmond, J.M., 1986, The $\mathrm{U}-\mathrm{Th}-\mathrm{Pb}$ systematics in hot springs on the East Pacific Rise at $21^{\circ} \mathrm{N}$ and Guaymas basin: Geochimica et Cosmochimica Acta, v. 50, p. 2467-2479.

Clift, P.D., 1995, Volcaniclastic sedimentation and volcanism during rifting of western Pacific backarc basins: Geophysical Monograph 88, p. 67-98.

Cochran, J.R., 1983, A model for development of Red Sea: American Association of Petroleum Geologists Bulletin, v. 67, p. 41-69.

Collier, J.S., and Sinha, M.C., 1992, Seimic mapping of a magma chamber beneath the Valu Fa Ridge, Lau basin: Journal of Geophysical Research, v. B97, p. 14,031-14,053.

Converse, D.R., Holland, H.D., and Edmond, J.M., 1984, Flow rates in the axial hot springs of the East Pacific Rise $\left(21^{\circ} \mathrm{N}\right)$ : Implications for the heat budget and the formation of massive sulfides: Earth and Planetary Science Letters, v. 69, p. 159-175.

Cronan, D. S., Varnavas, S., and Perissoratis, C., 1995, Hydrothermal sedimentation in the caldera of Santorini, Hellenic volcanic arc: Terra Research, v. 7, p. 289-293.

Cruse, A.M., and Seewald, J.S., 2001, Metal mobility in sediment-covered ridge-crest hydrothermal systems: Experimental and theoretical constraints: Geochimica et Cosmochimica Acta, v. 65, p. 3233-3247.

Curray, J.R., Moore, D.G., and Aguayo, J.E., 1982, Guaymas basin: Sites 477, 478, and 481: Initial Reports of the Deep Sea Drilling Project, v. 64, p. $211-415$.

Currie, R.G., and Davis, E.E., 1994, Low crustal magnetization of the Middle Valley sedimented rift inferred from sea-surface magnetic anomalies: Proceedings of the Ocean Drilling Program, Scientific Results, v. 139, p. $19-28.7 u$

Davis, E.E., and Fisher, A.T., 1994, On the nature and consequences of hydrothermal circulation in the Middle Valley sedimented rift: Inferences from geophysical and geochemical observations: Proceedings of the Ocean Drilling Program, Scientific Results, v. 139, p. 695-717.

Davis, E.E., and Villinger, H., 1992, Tectonic and thermal structure of the Middle Valley sedimented rift, northern Juan de Fuca Ridge: Proceedings of the Ocean Drilling Program, Initial Reports, v. 139, p. 9-42.

Davis, E.E., Mottl, M.J., and Fisher, A.T., eds., 1992, Proceedings of the Ocean Drilling Program, Initial Reports, v. 139, 459 p.

de Ronde, C.E.J., 1995, Fluid chemistry and isotopic characteristics of seafloor hydrothermal systems and associated VMS deposits: Potential for magmatic contributions: Mineralogical Association of Canada Short Course Series 23, p. 479-509.

de Ronde, C.E.J., de Wit, M.J., and Spooner, E.T.C., 1994, Early Archean (>3.2 Ga) Fe-oxide-rich hydrothermal discharge vents in the Barberton greenstone belt, South Africa: Geological Society of America Bulletin, v. 106 , p. 86-104.

de Ronde, C.E.J., Baker, E.T., Massoth, G.J., Lupton, J.E., Wright, I.C., Feely, R.A., and Greene, R.G., 2001, Intra-oceanic subduction-related hydrothermal venting, Kermadec volcanic arc, New Zealand: Earth and Planetary Science Letters, v. 193, p. 359-369.

de Ronde, C.E.J., Massoth, G.J., Baker, E.T., and Lupton, J.E., 2003, Submarine hydrothermal venting related to volcanic arcs: Society of Economic Geologists Special Publication 10, p. 91-109. de Ronde, C.E.I., Hannington, M.D., Stoffers, P., Wright, I.C., Ditchburn, R.G., Reyes, A.G., Baker, E.T., Massoth, G.J., Lupton, J.E., Walker, S.L., Greene, R.R., Soong, C.W.R., Ishibashi, J., Lebon, G.T., Bray, C.J., and Resing, J.A., 2005, Evolution of a submarine magmatic-hydrothermal system: Brothers volcano, southern Kermadec arc, New Zealand: Economic GEOLOGY, v. 100, in press.

Dekov, V.M., and Savelli, C., 2004, Hydrothermal activity in the SE Tyrrhenian Sea: An overview of 30 years of research: Marine Geology, v. 204, p. 161-185.

Delaney, J.R., Robigou, V., McDuff, R.E., and Tivey, M.K., 1992, Geology of a vigorous hydrothermal system on the Endeavour segment, Juan de Fuca Ridge: Journal of Geophysical Research, v. 97, p. 19,663-19,682.

Dick, H.J.B., Lian, J., and Schouten, H., 2003, An ultraslow-spreading class of ocean ridge: Nature, v. 426, p. 405-412.

Doe, B.R., 1994, Zinc, copper, and lead in mid-ocean ridge basalts and the source rock control on $\mathrm{Zn} / \mathrm{Pb}$ in ocean-ridge hydrothermal deposits Geochimica et Cosmochimica Acta, v. 58, p. 2215-2223.

Edmond, J.M., Measures, C., McDuff, R.E., Chan, L.H., Collier, R., Grant, B., Gordon, L.I., and Corliss, J.B., 1979a, Ridge crest hydrothermal activity and the balances of the major and minor elements in the ocean: The Galapagos data: Earth and Planetary Science Letters, v. 46, p. 1-18.

Edmond, J.M., Measures, C., Mangum, B., Grant, B., Sclater, F.R., Collier, R., and Hudson, A., 1979b, On the formation of metal-rich deposits at ridge crests: Earth and Planetary Science Letters, v. 46, p. 19-30

Edmond, J.M., Von Damm, K.L., McDuff, R.E., and Measures, C.I., 1982 , Chemistry of hot springs on the East Pacific Rise and their effluent dispersal: Nature, v. 297, p. 187-191.

Einsele, G., 1985, Basaltic sill-sediment complexes in young spreading centers: Genesis and significance: Geology, v. 13, p. 249-252.

Eissen, J.P., Nohara, M., and Cotten, J., 1994, North Fiji basin basalts and their magma sources. I. Incompatible element constraints: Marine Geology, v. 116, p. 163-178.

Elderfield, H., and Schultz, A., 1996, Mid-ocean ridge hydrothermal fluxes and the chemical composition of the ocean: Annual Review of Earth and Planetary Science, v. 24, p. 191-224.

Embley, R.W., Murphy, K.M., and Fox, C.G., 1990, High-resolution studies of the summit of Axial volcano: Journal of Geophysical Research, v. 95, p. $12,785-12,812$.

Embley, R.W., Chadwick, W.W., Perfit, M.R., Smith, M.C., and Delaney, J.R., 2000, Recent eruptions on the CoAxial segment of the Juan de Fuca Ridge: Implications for mid-ocean ridge accretion processes: Journal of Geophysical Research, v. 105, p. 16,591-16,525.

Embley, R.W., Baker, E.T., Chadwick, W.W., Jr., Lupton, J.E., Resing, J.A., Massoth, G.J., and Nakamura, K., 2004, Explorations of Mariana arc volcanoes reveal new hydrothermal systems: EOS, v. 85, p. 37-40.

Fisher, A.T., and Becker, K., 1991, Heat flow, hydrothermal circulation and basalt intrusions in the Guaymas basin, Gulf of California: Earth and Planetary Science Letters, v. 103, p. 84-99.

Fisher, A.T., Davis, E.E., Hutnak, M., Spiess, V., Zuehlsdorff, L., Cherkaoui, A., Christiansen, L., Edwards, K., Macdonald, R., Villinger, V., Mottl, M.J., Wheat, C.G., and Becker, K., 2003, Hydrothermal recharge and discharge across $50 \mathrm{~km}$ guided by seamounts on a young ridge flank: Nature, v. 421 , p. 618-621.

Fiske, R.S., Cashman, K.V., Shibata, A., and Watanabe, K., 1998, Tephra dispersal from Myojinsho, Japan, during its shallow submarine eruption of 1952-1953: Bulletin of Volcanology, v. 59, p. 262-275.

Fiske, R.S., Nada, J., Iizasa, K., Yuasa, M., and Klaus, A., 2001, Submarine silicic caldera at the front of the Izu-Bonin arc, Japan: Voluminous seafloor eruptions of rhyolite pumice: Geological Society of America Bulletin, v. 113 , p. 813-824.

Fornari, D.J., and Embley, R.W., 1995, Tectonic and volcanic controls on hydrothermal processes at the mid-ocean ridge: An overview based on nearbottom and submersible studies: Geophysical Monograph 91, p. 1-46.

Fouquet, Y., 1997, Where are the large hydrothermal sulphide deposits in the oceans?: Philosophical Transactions of the Royal Society of London, v A355, p. 427-441.

Fouquet, Y., and Marcoux, E., 1995, Lead isotope systematics in Pacific hydrothermal sulfide deposits: Journal of Geophysical Research, v. 100, p. 6025-6040.

Fouquet, Y., Auclair, G., Cambon, P., and Etoubleau, J., 1988, Geological setting, mineralogical, and geochemical investigations on sulfide deposits near $13^{\circ} \mathrm{N}$ on the East Pacific Rise: Marine Geology, v. 84, p. 145-178.

Fouquet, Y., von Stackelberg, U., Charlou, J.-L., Erzinger, J., Herzig, P.M., Muhe, R., and Wiedicke, M., 1993, Metallogenesis in back-arc environments: The Lau basin example: Economic GEOLOGY, v. 88, p. 2154-2181. 
Fouquet, Y., Ondreas, H., Charlou, J.-L., Donval, J.-P., Radford-Knoery, J., Costa, I., Lourenco, N., and Tivey, M.K., 1995, Atlantic lava lakes and hot vents: Nature, v. 377, p. 201.

Fouquet, Y., Zierenberg, R.A., and Miller, D.J., 1998, Investigation of hydrothermal circulation and genesis of massive sulfide deposits at sedimentcovered spreading centers at Middle Valley and Escanaba trough: Proceedings of the Ocean Drilling Program, Initial Reports, v. 169, p. 7-16.

Francheteau, J., Needham, H.D., Choukroune, P., Juteau, J., Seguret, M., Ballard, R.D., Fox, P.J., Normark, W., Carranza, A., Cordoba, A., Guerrero, J., Rangin, C., Bougault, H., Cambon, P., and Hekinina, R., 1979, Massive deep sea sulphide ore deposit discovered on the East Pacific Rise: Nature, v. 277 , p. $523-528$.

Franklin, J.M., Lydon, J.W., and Sangster, D.F., 1981, Volcanic-associated massive sulfide deposits: in Skinner, B.J., ed., ECONOMIC GEOLOGY 75TH ANNIVERSARY VOLUME, p. 485-627.

Franklin, J.M., Gibson, H.L., Jonassen, I.R., and Galley, A.G., 2005, Volcanogenic massive sulfide deposits: Economic GeOLOGY 100 ${ }^{\mathrm{TH}}$ ANNIVERSARY VOLUME, p. 523-560.

Früh-Green, G.L., Connolly, J.A.D., Kelley, D.S., Plas, A., and Grobety, B., 2004, Serpentinization of oceanic peridotites: Implications for geochemical cycles and biological activity, in Wilcock, W.S.D., Kelley, D.S., Baross, J.A., Cary, C., and DeLong, E., eds., The Subseafloor Biosphere at Mid-Ocean Ridges: Geophysical Monograph 144, American Geophysical Union, Washington, DC, p 119-136.

Früh-Green, G.L., Kelley, D.S., Bernasconi, S.M., Karson, J., Ludwig, K.A., Butterfield, D.A., Boschi, C., and Proskurowski, G., 2003, 30,000 years of hydrothermal activity at the Lost City vent field: Science, v. 301, p. 495-498.

Fryer, P., 1995, Geology of the Mariana trough, in Taylor, B., ed., Backarc basins: Tectonics and magmatism: New York, Plenum Press, p. 237-280.

Fryer, P., Taylor, B., Langmuir, C.H., and Hochstaedter, A.G., 1990, Petrology and geochemistry of lavas from the Sumisu and Torishima backarc rifts: Earth and Planetary Science Letters, v. 100, p. 161-178.

Fryer, P., Lockwood, J.P., Becker, N., Phipps, S., and Todd, C.S., 2000, Significance of serpentine mud volcanism in convergent margins: Geological Society of America Special Paper 349, p. 35-51.

Gaetani, G.A., Grove, T.L., and Bryan, W.B., 1993, The influence of water on the petrogenesis of subduction-related igneous rocks: Nature, v. 365, p. 332-334.

Galley, A.G., and Koski, R.A., 1999, Setting and characteristics of ophiolitehosted volcanogenic massive sulfide deposits: Reviews in Economic Geology, v. 8, p. 221-246.

Gamble, J.A., and Wright, I.C., 1995, The southern Havre trough geological structure and magma petrogenesis of an active backarc rift complex, in Taylor, B., ed., Backarc basins: Tectonics and magmatism: New York, Plenum Press, p. 29-62.

Gamo, T., Sakai, H., Kim, E.S., Shitashima, K., and Ishibashi, J., 1991, High alkalinity due to sulfate reduction in the Clam hydrothermal field, Okinawa trough: Earth and Planetary Science Letters, v. 107, p. 328-338.

Gamo, T., Sakai, H., Ishibashi, J., Nakayama, E., Isshiki, K., Matsuura, H., Shitashima, K., Takeuchi, K., and Ohta, S., 1993, Hydrothermal plumes in the eastern Manus basin, Bismarck Sea: $\mathrm{CH}_{4}, \mathrm{Mn}, \mathrm{Al}$, and $\mathrm{pH}$ anomalies: Deep Sea Research, v. 40, p. 2335-2349.

Gamo, T., Okamura, K., Charlou, J.-L., Urabe, T., Auzende, J.-M., Ishibashi, J., Shitashima, K., Chiba, H., and Shipboard Scientific Party, 1997, Acidic and sulfate-rich hydrothermal fluids from the Manus back-arc basin, Papua New Guinea: Geology, v. 25, p. 139-142.

Gemmell, J.B., Binns, R.A., and Parr, J.M., 1999, Submarine, high sulfidation alteration within DESMOS caldera, Manus basin, PNG, in Stanley, C.J., ed., Mineral deposits: Processes to processing: Proceedings of the Fifth Biennial SGA Meeting and the Tenth Quadrennial IAGOD Symposium: Rotterdam, Brookfield, VT, Balkema, p. 503-506.

Gemmell, J.B., Sharpe, R., Jonasson, I.R., and Herzig, P.M., 2004, Sulfur isotope evidence for magmatic contributions to submarine and subaerial gold mineralization: Conical seamount and the Ladolam gold deposit, Papua New Guinea: Economic Geology, v. 99, p. 1711-1725.

Gena, K., Mizuta, T., Ishiyama, D., and Urabe, T., 2001, Acid-sulphate type alteration and mineralization in the Desmos cauldron, Manus back-arc basin, Papua New Guinea: Resource Geology, v. 51, p. 31-44.

German, C.R., and Parson, L.M., 1998, Hydrothermal activity on the MidAtlantic Ridge: Interplay between magmatic and tectonic processes: Earth and Planetary Science Letters, v. 160, p. 327-341.

Gill, J.B., 1981, Orogenic andesites and plate tectonics: Berlin, Springer-Verlag, $390 \mathrm{p}$.
Glasby, G.P., 2000, Lessons learned from deep-sea mining: Science, v. 289, p. $551-553$.

Glasby, G.P., and Notsu, K., 2003, Submarine hydrothermal mineralization in the Okinawa trough, SW of Japan: An overview: Ore Geology Reviews, v. 23, p. 299-339.

Glasby, G.P., Iizasa, K., Yuasa, M., and Usui, A., 2000, Submarine hydrothermal mineralization on the Izu-Bonin arc: An overview: Marine Georesources and Geotechnology, v. 18, p. 141-176.

Godfrey, L.V., Mills, R., Elderfield, H., and Gurvich, E., 1994, Lead behaviour at the TAG hydrothermal vent field, $26^{\circ} \mathrm{N}$, Mid-Atlantic Ridge: Marine Chemistry, v. 46, p. 237-254.

Goodfellow, W.D., and Franklin, J.M., 1993, Geology, mineralogy, and chemistry of sediment-hosted clastic massive sulfides in shallow cores, Middle Valley, northern Juan de Fuca Ridge: Economic Geology, v. 88, p.2037-2068.

Goodfellow, W.D., and Zierenberg, R.A., 1999, Genesis of massive sulfide deposits at sediment-covered spreading centers: Reviews in Economic Geology, v. 8, p. 297-324.

Groves, D.I., and Barley, M.E., 1994, Archean mineralization: Developments in Precambrian Geology, v. 11, p. 461-503.

Guney, M., Al-Marhoun, M.A., and Nawab, Z.A., 1988, Metalliferous submarine sediments of the Atlantis II Deep, Red Sea: Canadian Institute of Mining and Metallurgy Bulletin, v. 81, p. 33-39.

Hajash, A., and Chandler, G.W., 1981, An experimental investigation of hightemperature interactions between seawater and rhyolite, andesite, basalt and peridotite: Contributions to Mineralogy and Petrology, v. 78, p. 240-254.

Halbach, P., Nakamura, K., Wahsner, M., Lange, J., Sakai, H., Kaselitz, L. Hansen, R-D., Yamano, M., Post, J., Prause, B., Seifert, R., Michaelis, W. Teichmann, F., Kinoshita, M., Marten, A., Ishibashi, J., Czerwinski, S., and Blum, N., 1989, Probable modern analogue of Kuroko-type massive sulphide deposits in the Okinawa trough back-arc basin: Nature, v. 338, p. 496-499.

Halbach, P., Pracejus, B., and Marten, A., 1993, Geology and mineralogy of massive sulfide ores from the central Okinawa trough: ECONOMIC GEOLOGY, v. 88 , p. 2210-2225.

Hannington, M.D., and Scott, S.D., 1989, Gold mineralization in volcanogenic massive sulfides: Implications of data from active hydrothermal vents on the modern sea floor: Economic Geology Monograph 6, p. 491-507.

Hannington, M., Herzig, P., Scott, S., Thompson, G., and Rona, P., 1991a Comparative mineralogy and geochemistry of gold-bearing sulfide deposits on the mid-ocean ridges: Marine Geology, v. 101, p. 217-248.

Hannington, M.D., Herzig, P.M., and Scott, S.D., 1991b, Auriferous hydrothermal precipitates on the modern seafloor, in Foster, R.P., ed., Gold metallogeny and exploration: Glasgow, Blackie, p. 249-282.

Hannington, M.D., Petersen, S., Jonasson, I.R., and Franklin, J.M., 1994, Hydrothermal activity and associated mineral deposits on the seafloor: $\mathrm{Ge}-$ ological Survey of Canada Open File Report 2915C, map 1:35,000,000 and CD-ROM

Hannington, M.D., Jonasson, I.R., Herzig, P.M., and Petersen, S., 1995 Physical and chemical processes of seafloor mineralization: Geophysical Monograph 91, p. 115-157.

Hannington, M.D., Galley, A.G., Herzig, P.M., and Petersen, S., 1998, A comparison of the TAG Mound and stockwork complex with Cyprus-type massive sulfide deposits: Proceedings of the Ocean Drilling Program, Scientific Results, v. 158, p. 389-415.

Hannington, M.D., Poulsen, K.H., Thompson, J.F.H., and Sillitoe, R.H., 1999, Volcanogenic gold in the massive sulfide environment: Reviews in Economic Geology, v. 8, p. 319-350.

Hannington, M.D., Herzig, P., Stoffers, P., Scholten, J., Garbe-Schonberg D., Jonasson, I.R., Roest, W., and Shipboard Scientific Party, 2001, First high-temperature submarine hydrothermal vents and massive anhydrite deposits off the north coast of Iceland: Marine Geology, v. 177, p. 199-220.

Hannington, M.D., Petersen, S., Herzig, P.M., and Jonasson, I.R., 2004, A global database of seafloor hydrothermal systems, including a digital database of geochemical analyses of seafloor polymetallic sulfides: Geological Survey of Canada Open File 4598, CD-ROM.

Hartmann, M., 1980, Atlantis II Deep geothermal brine system: Hydrographic situation in 1977 and changes since 1965: Deep Sea Research, v. 127 , p. 161-171.

1985, Atlantis II Deep geothermal brine system: Chemical processes between hydrothermal brines and Red Sea deep water: Marine Geology, v. 64, p. 157-177. 
Hawkins, J.W., 1995, The geology of the Lau basin, in Taylor, B., ed., Backarc basins: Tectonics and magmatism: New York, Plenum Press, p. 63-138.

Haymon, R.M., Fornari, D.J., Edwards, M.H., Carbotte, S., Wright, D., and Macdonald, K.C., 1991, Hydrothermal vent distribution along the East Pacific Rise crest $\left(9^{\circ} 09^{\prime}-54^{\prime} \mathrm{N}\right)$ and its relationship to magmatic and tectonic processes on fast-spreading mid-ocean ridges: Earth and Planetary Science Letters, v. 104, p. 513-534

Haymon, R.M., Fornari, D.J., Von Damm, K.L., Lilley, M.D., Perfit, M.R., Edmond, J.M., Shanks, W.C., Lutz, R.A., Grebmeier, J.M., Carbotte, S., Wright, D., McLaughlin, E., Smith, M., Beedle, N., and Olson, E., 1993, Volcanic eruption of the mid-ocean ridge along the East Pacific Rise crest at $9^{\circ} 45-52^{\prime} \mathrm{N}$ : Direct submersible observations of seafloor phenomenon associated with an eruption in April 1991: Earth and Planetary Science Letters, v. 119, p. 85-101.

Hedenquist, J.W., Simmons, S.F., Giggenbach, W.F., and Eldridge, C.S., 1993, White Island, New Zealand, volcanic hydrothermal system represents the geochemical environment of high-sulfidation $\mathrm{Cu}$ and $\mathrm{Au}$ ore deposition: Geology, v. 21, p. 731-734.

Hekinian, R., Fevrier, M., Bischoff, J. L., Picot, P., and Shanks, W. C., 1980, Sulfide deposits from the East Pacific Rise near $21^{\circ} \mathrm{N}$ : Science, v. 207, p. $1433-1444$.

Hekinian, R., Hoffert, M., Larque, P., Cheminée, J.L., Stoffers, P., and Bideau, D., 1993, Hydrothermal Fe and Si oxyhydroxide deposits from South Pacific iIntraplate volcanoes and East Pacific Rise axial and off-axial regions: ECONOMIC GEOLOGY, v. 88, p. 2099-2121.

Hekinian, R., Stoffers, P., Ackermand, D., Revillon, S., Maia, M., and Bohn, M., 1999, Ridge-hotspot interaction: The Pacific-Antarctic Ridge and the Foundation Seamounts: Marine Geology, v. 160, p. 199-223.

Herzig, P.M., and Hannington, M.D., 1995, Polymetallic massive sulfides at the modern seafloor-a review: Ore Geology Reviews, v. 10, p. 95-115.

Herzig, P.M., Hannington, M.D., Fouquet, Y., von Stackelberg, U., and Petersen, S., 1993, Gold-rich polymetallic sulfides from the Lau back arc and implications for the geochemistry of gold in sea-floor hydrothermal systems of the Southwest Pacific: Economic Geology, v. 88, p. 2182-2209.

Herzig, P.M., Hannington, M.D., and Arribas, A., 1998, Sulfur isotopic composition of hydrothermal precipitates from the Lau back-arc: Implications for magmatic contributions to seafloor hydrothermal systems: Mineralium Deposita, v. 33, p. 226-237.

Honma, H., Kusakabe, M., Kagami, H., Iizumi, S., Sakai, H., Kodama, Y., and Kimura, M., 1991, Major and trace element chemistry and D/H, ${ }^{18} \mathrm{O} /{ }^{16} \mathrm{O},{ }^{87} \mathrm{Sr} /{ }^{86} \mathrm{Sr}$ and ${ }^{143} \mathrm{Nd} /{ }^{144} \mathrm{Nd}$ ratios of rocks from the spreading center of the Okinawa trough, a marginal back-arc basin: Geochemical Journal, v. 25 , p. $121-136$

Honnorez, J., Honnorez-Guerstein, B., Valette, J., and Wauschkuhn, A., 1973, Present-day formation of an exhalative sulfide deposit at Vulcano (Tyrrhenian Sea), Part II. Active crystallization of fumarolic sulfides in the volcanic sediments of the Baia de Levante, in Amstutz, G.C., and Bernard, A.J., eds., Ores in sediments: Berlin, Springer-Verlag, International Union of Geological Sciences, ser. A, no. 3, p. 140-166.

Humphris S.E, and Cann, J.R., 2000, Constraints on the energy and chemical balances of the modern TAG and ancient Cyprus seafloor sulfide deposits: Journal of Geophysical Research, v. 105, p. 28,477-28,488.

Humphris, S.E., and Tivey, M.K., 2000, A synthesis of geological and geochemical investigations of the TAG hydrothermal field: Insights into fluid flow and mixing process in a hydrothermal system, in Dilek, Y., Moores, E., Elthon, D., and Nicholas, A., eds., Ophiolites and oceanic crust: New insights from field studies and the ocean drilling program: Boulder, $\mathrm{CO}, \mathrm{Ge}-$ ological Society of America, p. 213-236.

Humprhis, S.E., Herig, P.M., and Miller, D.J., and Leg 158 Shipboard Scientific Party, 1995, The internal structure of an active sea-floor massive sulphide deposit: Nature, v. 377, p. 713-716.

Iizasa, K., Yusa, M., and Yokota, S., 1992, Mineralogy and geochemistry of volcanogenic sulfides from the Myojinsho submarine caldera, the SichitoIwojima Ridge, Izu-Ogasawara arc, northwestern Pacific: Marine Geology, v. 108 , p. $39-58$

Iizasa, K., Fiske, R.S., Ishizuka, O., Yuasa, M., Hashimoto, J, Ishibashi, J., Naka, J., Horii, Y., Fujiwara, Y., Imai, A., and Koyama, S.A., 1999, A kuroko-type polymetallic sulfide deposit in a submarine silicic caldera: Science, v. 283, p. 975-977.

Ikeda, Y., and Yuasa, M., 1989, Volcanism in nascent back-arc basins behind the Shichito Ridge and adjacent areas in the Izu-Ogasawara arc northwest Pacific: Evidence for mixing between E-type MORB and island arc magmas at the initiation of back-arc rifting: Contributions to Mineralogy and Petrology, v. 101, p. 377-393.
Ishibashi, J., and Urabe, T., 1995, Hydrothermal activity related to arcbackarc magmatism in the Western Pacific, in Taylor, B., ed., Backarc basins: Tectonics and magmatism: New York, Plenum Press, p. 451-495.

Ishibashi, J., Tsunogai, U., Wakita, H., Watanabe, K., Kajimura, T., Shibata, A., Fujiwara, Y., and Hashimoto, J., 1994, Chemical composition of hydrothermal fluids from Suiyo and Mokuyo Seamounts, Izu-Bonin arc: Deep Sea Research, v. 10., p. 89-97.

Ishizuka, H., Kawanobe, Y., and Sakai, H., 1990, Petrology and geochemistry of volcanic rocks dredged from the Okinawa trough, an active back-arc basin: Geochemical Journal, v. 24, p. 75-92.

Ishizuka, O., Yuasa, M., and Uto, K., 2002, Evidence of porphyry copper-type hydrothermal activity from a submerged back-arc volcano of the Izu Bonin arc: Implications for the volcanotectonic history of back-arc seamounts: Earth and Planetary Science Letters, v. 198, p. 381-399

Jambon, A., 1994, Earth degassing and large-scale geochemical cycling of volatile elements: Reviews in Mineralogy, v. 30, p. 479-517.

Janecky, D.R., and Seyfried, W.E., Jr., 1983, The solubility of magnesium-hydroxide-sulfate-hydrate in seawater at elevated temperatures and pressures: American Jounral of Science, v. 283, p. 831-860.

-1984, Formation of massive sulfide deposits on oceanic ridge crests: Incremental reaction models for mixing between hydrothermal solutions and seawater: Geochimica et Cosmochimica Acta, v. 48, p. 2723-2738.

Kadko, D., Koski, R., Tatsumoto, M., and Bouse, R., 1985, An estimate of hydrothermal fluid residence times and vent chimney growth rates based on ${ }^{210} \mathrm{~Pb} / \mathrm{Pb}$ ratios and mineralogic studies of sulfides dredged from the Juan de Fuca Ridge: Earth and Planetary Science Letters, v. 76, p. 35-44.

Kadko, D., Barross, J., and Alt, J.C., 1995, The magnitude and global implications of hydrothermal flux: Geophysical Monograph 91, p. 446-466.

Kamenetsky, V.S., Binns, R.A., Gemmell, J.B., Crawford, A.J., Mernagh, T.P., Mas, R., and Steele, D., 2001, Parental basaltic melts and fluids in eastern Manus backarc basin: Implications for hydrothermal mineralization: Earth and Planetary Science Letters, v. 184, p. 685-702.

Karig, D., 1970, Ridges and basins of the Tonga-Kermadec island arc system: Journal of Geophysical Research, v. B75, p. 239-254.

Karson, J.A., 2002, Geologic structure of upper-most oceanic crust from fastto intermediate-rate Mid-Ocean Ridges: Annual Review of Earth and Planetary Science, v. 30, p. 347-384.

Karson, J.A., and Rona, P.A., 1990, Block-tilting, transfer faults, and structural control of magmatic and hydrothermal processes in the TAG area Mid-Atlantic Ridge $26^{\circ} \mathrm{N}$ : Geological Society of America Bulletin, v. 102, p. $1635-1645$.

Keller, R.A., Fisk, M.R., Smellie, J.L., Strelin, J.A., and Lawver, L.A., 2002 , Geochemistry of back-arc basin volcanism in Bransfield Strait, Antarctica Subducted contributions and along-axis variations: Journal of Geophysical Research, v. 107, 17 p., DOI10.1029/2001JB000444.

Kelley D.S., and Delaney, J.R., 1987, Two-phase separation and fracturing in mid-ocean ridge gabbros at temperatures greater than $700^{\circ} \mathrm{C}$ : Earth and Planetary Science Letters, v. 83, p. 53-66.

Kelley, D.S., and Früh-Green, G.L., 1999, Abiogenic methane in deepseated mid-ocean ridge environments: Insights from stable isotope analyses: Journal of Geophysical Research, v. B104, p. 10439-10460.

2000, Volatiles in mid-ocean ridge environments, in Dilek, Y., Moores, E., Elthon, D., and Nicholas, A., eds., Ophiolites and oceanic crust: New insights from field studies and the ocean drilling program: Boulder, $\mathrm{CO}$, Geological Society of America, p. 237-260.

2001, Volatile lines of descent in submarine plutonic environments: Insights from stable isotope and fluid inclusion analyses: Geochimica et Cosmochimica Acta, v. 65, p. 3325-3346.

Kelley, D.S., Baross, J.A., and Delaney, J.R., 2002, Volcanoes, fluids, and life at mid-ocean ridge spreading centers: Annual Review of Earth and Planetary Science, v. 30, p. 385-491.

Kelley, D.S., Delaney, J.R., and Yoerger, D.A., 2001a, Geology and venting characteristics of the Mothra hydrothermal field, Endeavour segment, Juan de Fuca Ridge: Geology, v. 29, p. 959-962

Kelley, D.S., Karson, J.A., Blackman, D.K., Früh-Green, G.L., Butterfield, D.A., Lilley, M.D., Olson, E.J., Schrenk, M.O., Roe, K.K., Lebon, G.T., Rivizzigno, P. and the AT3-60 Shipboard Party, 2001b, An off-axis hydrothermal vent field near the Mid-Atlantic Ridge at $30^{\circ} \mathrm{N}$ : Nature v. 412, p. 145-149.

Kerrich, R., and Wyman, D.A., 1997, Review of developments in trace element fingerprinting of geodynamic settings and their implications for mineral exploration: Australian Journal of Earth Sciences, v. 44, p. 465-487.

Kimura, M., Uyeda, S., Kato, Y., Tanaka, T., Yamano, M., Gamo, T., Sakai, H., Kato, S., Izawa, E., and Oomori, T., 1988, Active hydrothermal mounds in the Okinawa trough backarc basin: Tectonophysics, v. 145, p. 319-324. 
Kleinrock, M.C., and Humphris, S.E., 1996, Structural control on sea-floor hydrothermal activity at the TAG active mound: Nature, v. 382, p. 149-153. Klinkhammer, G.P., Chin, C.S., Keller, R.A., Daehlmann, A., Sahling, H., Sarthou, G., Petersen, S., Smith, F., and Wilson, C., 2001, Discovery of new hydrothermal vent sites in Bransfield Strait, Antarctica: Earth and Planetary Science Letters, v. 193, p 395-407.

Koski, R.A., Lonsdale, P.F., Shanks, W.C., Berndt, M.E., and Howe, S.S., 1985, Mineralogy and geochemistry of a sediment-hosted hydrothermal sulfide deposit from the southern trough of Guaymas basin, Gulf of California: Journal of Geophysical Research, v. 90, p. 6695-6707.

Koski, R.A., Shanks, W.C., III, Bohrson, W.A., and Oscarson, R.L., 1988, The composition of massive sulfide deposits from the sediment-covered floor of Escanaba trough, Gorda Ridge: Implications for depositional processes: Canadian Mineralogist, v. 26, p. 655-674.

Koski, R.A., Jonasson, I.R., Kadko, D.C., Smith, V.K., and Wong, F.L., 1994, Compositions, growth mechanisms, and temporal relations of hydrothermal sulfide-sulfate-silica chimneys at the northern Cleft segment, Juan de Fuca Ridge: Journal of Geophysical Research, v. 99, p. 4813-4832.

Krasnov, S.G., Proroshina, I.M., and Cherkashev, G.A., 1995, Geological setting of high-temperature hydrothermal activity and massive sulphide formation on fast and slow-spreading ridges: Geological Society of London Special Publication 87, p. 17-32.

Lagabrielle, Y., Bideau, D., Cannat, M., Karson, J.A., and Mével, C., 1998, Ultramafic plutonic rocks exposed along the mid-Atlantic Ridge $\left(10^{\circ} \mathrm{N}\right.$ $30^{\circ} \mathrm{N}$ ): Symmetrical-asymmetrical distribution and implications for seafloor spreading processes: Geophysical Monograph 106, p. 153-176.

Lalou C., Thompson, G., Arnold, M., Brichet, E., Druffel, E., and Rona, P.A., 1990, Geochronology of TAG and Snakepit hydrothermal fields, Mid-Atlantic Ridge: Witness to a long and complex hydrothermal history: Earth and Planetary Science Letters, v. 97, p. 113-128.

Lalou, C., Reyss, J.-L., Brichet, E., Rona, P.A., and Thompson, G., 1995, Hydrothermal activity on a $10^{5}$-year scale at slow-spreading ridge, TAG hydrothermal field, Mid-Atlantic Ridge $26^{\circ} \mathrm{N}$ : Journal of Geophysical Research, v. 100 , p. $17,855-17,862$.

-1998, Age of sub-bottom sulfide samples at the TAG active mound: Proceedings of the Ocean Drilling Program, Scientific Results, v. 158, p. $111-117$.

Langmuir, C., Humphris, S., Fornari, D., Van Dover, C., Von Damm, K., Tivey, M.K., Colodner, D., Charlou, J.-L., Desonie, D., Wilson, C., Fouquet, Y., Klinkhammer, G., and Bougault, H., 1997, Hydrothermal vents near a mantle hot spot: Lucky Strike vent field at $37^{\circ} \mathrm{N}$ on the Mid-Atlantic Ridge: Earth and Planetary Science Letters, v. 148, p. 69-91.

Lawver, L.A., Keller, R.A., Fisk, M.R., and Stelin, J.A., 1995, Active extension behind a dead arc, in Taylor, B., ed., Backarc basins: Tectonics and magmatism: New York, Plenum Press, p. 315-342.

Le Cloarec, M.F., Allard, P., Ardouin, B., Giggenbach, W.F., and Sheppard, D.S., 1992, Radioactive isotopes and trace elements in gaseous emissions from White Island, New Zealand: Earth and Planetary Science Letters, v. 108 , p. 19-28.

LeHuray, A.P., Church, S.E., Koski, R.A., and Bouse, R.M., 1988, Pb isotopes in sulfides from mid-ocean ridge hydrothermal sites: Geology, v. 16, p. $362-365$

Lilley, M.D., Butterfield, D.A., Olson, E.J., Lupton, J.E., Macko, S.A., and McDuff, R.E., 1993, Anomalous $\mathrm{CH}_{4}$ and $\mathrm{NH}_{4}{ }^{+}$concentrations at an unsedimented mid-ocean ridge hydrothermal system: Nature, v. 364, p. 45-47.

Lilley, M.D., Feely, R.A., and Trefry, J.H., 1995, Chemical and biochemical transformations in hydrothermal plumes: Geophysical Monograph 91, p. 369-391.

Lisitsyn, A.P., Malahoff, A.R., Bogdanov, Y.A., Soakai, S., Zonenshayn, L.P., Gurvich, Y.G., Murav'yev, K.G., and Ivanov, G.V., 1992, Hydrothermal formations in the northern part of the Lau basin, Pacific Ocean: International Geology Review, v. 34, p. 828-847.

Lisitsyn, A.P., Crook, K.A.W., Bogdanov, Y. A., Zonenshayn, L.P., Murav'yev, K.G., Tufar, W., Gurvich, Y.G., Gordeyev, V.V., and Ivanov, G.V., 1993, A hydrothermal field in the rift zone of the Manus basin, Bismarck Sea: International Geology Review, v. 35, p. 105-126.

Lonsdale, P. 1991, Structural patterns of the Pacific floor offshore of Peninsular California: American Association of Petroleum Geologists Memoir 47, p. $87-125$.

Lonsdale, P., and Becker, K., 1985, Hydrothermal plumes, hot springs, and conductive heat flow in the southern trough of Guaymas basin: Earth and Planetary Science Letters, v. 73, p. 211-225.

Lowell, R.P., 1991, Modelling continental and submarine hydrothermal systems: Reviews of Geophysics, v. 29, p. 457-476.
Lowell, R.P., Rona, P.A., and Von Herzen, R.P., 1995, Seafloor hydrothermal systems: Journal of Geophysical Research, v. 100, p. 327-352.

Macdonald, K.C., 1998, Linkages between faulting, volcanism, and hydrothermal activity and segmentation on fast-spreading centers: Geophysical Monograph 106, p. 27-58.

Macdonald, R., Hawkesworth, C.J., and Heath, E., 2000, The Lesser Antilles volcanic chain: A study in arc magmatism: Earth Science Reviews, v. 49, p. $1-76$.

MacLeod, C.J., Escartin, J., Banerji, D., Banks, G.J., Gleeson, M., Irving, D.H.B., Lilly, R.M., McCaig, A.M., Niu, Y., Allerton, S., and Smith, D.K. 2002, Direct geological evidence for oceanic detachment faulting; the MidAtlantic Ridge, $15^{\circ} 45^{\prime} \mathrm{N}$ : Geology, v. 30, p. 879-882.

Madge, L.S., Barclay, A.H., Toomey, D.R., Detrick, R.S., and Collins, J.A 2000, Crustal magma plumbing within a segment of the Mid-Atlantic Ridge, $35^{\circ} \mathrm{N}$ : Earth and Planetary Science Letters, v. 175, p. 55-67.

Manning, C.E., MacLeod, C.J., and Weston, P.E., 2000, Lower-crustal cracking front at fast-spreading ridges: Evidence from the East Pacific Rise and Oman ophiolites: Geological Society of America Special Paper 349, p. 261-272.

Marani, M.P., Gamberi, F., and Savelli, C., 1997, Shallow-water polymetallic sulfide deposits in the Aeolian island arc: Geology, v. 25, p. 815-818.

Martinez, F., and Taylor, B., 1996, Backarc spreading, rifting, and microplate rotation between transform faults in the Manus basin: Marine Geophysical Researches, v. 18, p. 203-224.

Marumo, K., and Hattori, K.H., 1999, Seafloor hydrothermal clay alteration at Jade in the back-arc Okinawa trough: Mineralogy, geochemistry and isotope characteristics: Geochimica et Cosmochimica Acta, v. 63, p. 2785-2804 Massoth, G.J., Butterfield, D.A., Lupton, J.E., McDuff, R.E., Lilley, M.D., and Jonasson, I.R., 1989, Submarine venting of phase-separated hydrothermal fluids at Axial volcano, Juan de Fuca Ridge: Nature, v. 340, p $702-705$.

Massoth, G.J., Baker, E.T., and Lupton, J.E., 1994, Temporal and spatial variability of hydrothermal manganese and iron at Cleft segment, Juan de Fuca Ridge: Journal of Geophysical Research, v. 99, p. 4905-4923.

Massoth, G.J., de Ronde, C.E.J., Lupton, J.E., Feely, R.A., Baker, E.T., Lebon, G.T., and Maenner, S.M., 2003, Chemically rich and diverse submarine hydrothermal plumes of the southern Kermadec volcanic arc (New Zealand): Geological Society of London Special Publication 219, p. $119-139$

McCollom, T.M., and Seewald, J.S., 2001, A reassessment of the potential for reduction of dissolved $\mathrm{CO}_{2}$ to hydrocarbons during serpentinization of olivine: Geochimica et Cosmochimica Acta, v. 65, p. 3769-3778.

McInnes, B.I.A., and Cameron, E.M., 1994, Carbonated, alkaline hybridizing melts from a sub-arc environment: Mantle wedge samples from the Tabar-Lihir-Tanga-Feni Arc, Papua New Guinea: Earth and Planetary Science Letters, v. 122, p. 125-141.

McInnes, B.I.A., Gregoire, M., Binns, R.A., Herzig, P.M., and Hannington, M.D., 2001, Hydrous metasomatism of oceanic sub-arc mantle, Lihir, Papua New Guinea: Petrology and geochemistry of fluid-metasomatised mantle wedge xenoliths: Earth and Planetary Science Letters, v. 188, p. 169-183.

McMurtry, G.M., Sedwick, P.N., Fryer, P., VonderHaar, D.L., and Yeh, H.W., 1993, Unusual geochemistry of hydrothermal vents on submarine arc volcanoes: Kasuga Seamounts, northern Mariana arc: Earth and Planetary Science Letters, v. 114, p. 517-528.

Menzies, M.A., Klemperer, S.L., Ebinger, C.J., and Baker, J., 2002, Characteristics of volcanic rifted margins: Geological Society of America Special Paper 362, p. 1-14.

Mével, C., 2003, Serpentinization of abyssal peridotites at mid-ocean ridges: Comptes Rendus, Geoscience, v. 335, p. 825-852.

Michael, P.J., Langmuir, C.H., Dick, H.J.B., Snow, J.E., Goldsteine, S.L., Graham, D.W., Lehnert, K., Kurras, G., Jokat, W., Mühe, R., and Edmonds, H.N., 2003, Magmatic and amagmatic seafloor generation at the ultraslow-spreading Gakkel ridge, Arctic Ocean: Nature, v. 423, p. 956-961.

Michard, A., Michard, G., Stueben, D., Stoffers, P., Cheminée, J.-L. and Binard, N., 1993, Submarine thermal springs associated with young volcanoes: The Teahitia vents, Society Islands, Pacific Ocean: Geochimica et Cosmochimica Acta, v. 57, p. 4977, 4986.

Minniti, M., and Bonavia, F.F., 1984, Copper-ore grade hydrothermal mineralization discovered in a seamount in the Tyrrhenian sea (Mediterranean): Is the mineralization related to porphyry coppers or to base metal lodes?: Marine Geology, v. 59, p. 271-282.

Morgan, C.J., 2000, Resource estimates of the Clarion-Clipperton manganese nodule deposits, in Cronan, D.S., ed., Handbook of marine mineral deposits: Boca Raton, FL, CRC Press, p. 145-170. 
Moss, R., and Scott, S.D., 2001, Geochemistry and mineralogy of gold-rich hydrothermal precipitates from the eastern Manus basin, Papua New Guinea: Canadian Mineralogist, v. 39, p. 957-978.

Mottl, M.J., 2003, Partitioning of heat and mass fluxes between midocean ridge axes and flanks at high and low temperature, in Halbach, P., Tunnicliffe, V., and Hein, J., eds., Energy and mass transfer in hydrothermal systems: Dahlem Workshop Report, Dahlem University Press, p. 271-286.

Mozgova, N.N., Krasnov, S.G., Batuev, B.N., Borodaev, Y.S., Efimov, A.V., Markov, V.F., and Stepanov, T.V., 1996, Cobalt pentalandite from an oceanic hydrothermal deposits $\left(14^{\circ} 45^{\prime} \mathrm{N}\right.$ Mid-Atlantic Ridge: Canadian Mineralogist, v. 34, p. 23-28.

Mozgova, N.N., Efimov, A.V., Borodaev, Y.S., Krasnov, S.G., Cherkashev, G.A, Stepanova, T.V., and Ashadze, A.M., 1999, Mineralogy and chemistry of massive sulfides from the Logatchev hydrothermal field $\left(14^{\circ} 45^{\prime} \mathrm{N}\right.$ MidAtlantic Ridge): Exploration and Mining Geology, v. 8, p. 379-395.

Murphy, P.J., and Meyer, G., 1998, A gold-copper association in ultramafichosted hydrothermal sulfides from the Mid-Atlantic Ridge: ECONOMIC GEOLOGY, v. 93 , p. 1076-1083

Nakashima, K., Sakai, H., Yoshida, H., Chinba, H., Tanaka, Y., Gamo, T., and Tsunogai, U., 1995, Hydrothermal mineralization in the mid-Okinawa trough, in Sakai H., and Nozaki, Y., eds., Biogeochemical processes and ocean flux in the Western Pacific: Tokyo, Terra Scientific Publishing, p. $487-508$.

Normark, W.R., and Reid, J.A., 2003, Extensive deposits on the pacific plate from late Pleistocene North American glacial outbursts: Journal of Geology, v. 111 , p. $617-637$.

Ohmoto, H., 1983, Geologic setting of the Kuroko deposits, Japan: Part I. Geologic history of the Green Tuff region: Economic Geology MonoGRAPH 5, p. 9-24.

1996, Formation of volcanogenic massive sulfide deposits: The Kuroko perspective: Ore Geology Reviews, v. 10, p. 135-177.

Oudin, E., Thisse, Y., and Ramboz, C., 1984, Fluid inclusion and mineralogical evidence for high-temperature saline hydrothermal circulation in the Red Sea metalliferous sediments: Preliminary results: Marine Mining, v. 5, p. 3-31

Palandri, J.L., and Reed, M.H., 2004, Geochemical models of metasomatism in ultramafic systems: Serpentinization, rodingitization, and sea floor carbonate chimney precipitation: Geochimica et Cosmochimica Acta, v. 68, p. $1115-1133$

Pan, Y., and Xie, Q., 2001, Extreme fractionation of platinum group elements in volcanogenic massive sulfide deposits: ECONOMIC GEOLOGY, v. 96, p. $645-651$.

Pantin, H.M., and Wright, I.C., 1994, Submarine hydrothermal activity within the offshore Taupo Volcanic Zone, Bay of Plenty continental shelf, New Zealand: Continental Shelf Research, v. 14, p. 1411-1438.

Parson, L.M., and Wright, I.C., 1996, The Lau-Havre-Taupo back-arc basin; A southward-propagating, multi-stage evolution from rifting to spreading: Tectonophysics, v. 263, p. 1-22.

Pearce, J.A., and Peate, D.W., 1995, Tectonic implications of the composition of volcanic arc magmas: Annual Review of Earth and Planetary Sciences, p. 23, p. 251-285.

Pearce, J.E., Ernewein, M., Bloomer, S.H., Parson, L.M., Murton, B.J., and Johnson, L.E., 1995, Geochemistry of Lau Basin volcanic rocks: Influence of ridge segmentation and arc proximity: Geological Society of London Special Publication 81, p. 53-75.

Pelletier, B., Calmant, S., and Pillet, R., 1998, Current tectonics of the Tonga-New Hebrides region: Earth and Planetary Science Letters, v. 164, p. 263-276.

Perfit, M.R., and Chadwick, W.W., Jr., 1998, Magmatism at mid-ocean ridges: Constraints from volcanological and geochemical investigations: Geophysical Monograph 106, p. 59-115.

Perfit, M.R., and Davidson, J.P., 2000, Plate tectonics and volcanism, in Sigurdsson, H., Houghton, B.F., McNutt, S.R., Rymer, H., Stix, J., and Ballard, R.D., eds., Encyclopedia of volcanoes: San Diego, CA, Academic Press, p. 89-113.

Perfit, M.R., Ridley, W., and Jonasson, I.R., 1999, Geologic, petrologic, and geochemical relationships between magmatism and massive sulfide mineralization along the eastern Galapagos spreading center: Reviews in Economic Geology, v. 8, p. $75-100$

Peter, J.M., and Scott, S.D., 1988, Mineralogy, composition, and fluid inclusion microthermometry of seafloor hydrothermal deposits in the southern trough of Guaymas Basin, Gulf of California: Canadian Mineralogist, v. 26, p. $567-588$
1991, Hydrothermal mineralization in the Guaymas basin, Gulf of California: American Association of Petroleum Geologists Memoir 47, p. $721-741$

Peter, J.M., Goodfellow, W.D., and Leybourne, M.I., 1994, Fluid inclusion petrography and microthermometry at the Middle Valley hydrothermal system, northern Juan de Fuca Ridge: Proceedings of the Ocean Drilling Program, Scientific Results, v. 139, p. 411-428.

Peter, J.M., Peltonen, P., Scott, S.D., Simoneit, B.R.T., and Kawka, O.E., 1991, ${ }^{14} \mathrm{C}$ ages of hydrothermal petroleum and carbonate in Guaymas basin, Gulf of California: Implications for oil generation, expulsion, and migration: Geology, v. 19, p. 253-256.

Peter, J.M., Simoneit, B.R.T., Kawka, O.E., and Scott, S.D., 1990, Liquid hydrocarbon-bearing inclusions in modern hydrothermal chimneys and mounds from the southern trough of Guaymas basin: Applied Geochemistry, v. 5, p. 51-63.

Petersen, S., Herzig, P. M., and Hannington, M. D., 2000, Third dimension of a presently forming VMS deposit: TAG hydrothermal mound, Mid-Atlantic Ridge, $26^{\circ}$ N: Mineralium Deposita, v. 35, p. 233-259.

Petersen, S., Herzig, P.M., Hannington, M.D., Jonasson, I.R., and Arribas, A.J., 2002, Submarine vein-type gold mineralization near Lihir island, New Ireland fore-arc, Papua New Guinea: Economic Geology, v. 97, p. $1795-1813$

Petersen, S., Schwarz-Schampera, U., Herzig, P.M., Hannington, M.D., and Jonasson, I.R., 2004, Hydrothermal precipitates associated with bimodal volcanism in the Central Bransfield Strait, Antarctica: Mineralium Deposita, v. 39, p. 358-379.

Pottorf, R.J., and Barnes, H.L., 1983, Mineralogy, geochemistry, and ore genesis of hydrothermal sediments from the Atlantis II Deep, Red Sea: ECONOMiC GEOLOGY Monograph 5, p. 198-223.

Poulsen, K.H., Card, K.D., and Franklin, J.M., 1992, Archean tectonic and metallogenic evolution of the Superior province of the Canadian Shield: Precambrian, v. 58, p. 25-54.

Ramboz, C., and Danis, M., 1990, Superheating in the Red Sea? The heatmass balance of the Atlantis II Deep revisited: Earth and Planetary Science Letters, v. 97, p. 190-210.

Ramboz, C., Oudin, E., and Thisse, Y., 1988, Geyser-type discharge in the Atlantis II Deep, Red Sea: Evidence of boiling from fluid inclusions in epigenetic anhydrite: Canadian Mineralogist, v. 26, p. 765-786.

Resing, J.A., and Sansone, F.J., 1996, Al and pH anomalies in the Manus basin appraised: Deep Sea Research, v. 43, p. 1867-1872.

Rona, P.A., 1984, Hydrothermal mineralization at seafloor spreading centers: Earth Science Reviews, v. 20, p. 1-104.

1988, Hydrothermal mineralization at oceanic ridges: Canadian Mineralogist, v. 26, p. 431-465.

2003, Resources of the seafloor: Science, v. 299, p. 673-674

Rona, P.A., and Scott, S.D., 1993. Preface to special issue on sea-floor hydrothermal mineralization: New perspectives: ECONOMIC GEOLOGY, v. 88 , p. 1935-1976.

Rona, P.A., and Trivett, D.A., 1992, Discrete and diffuse heat transfer at ASHES vent field, Axial volcano, Juan de Fuca Ridge: Earth and Planetary Science Letters, v. 109, p. 57-71.

Rona, P.A., Bostrom, K., Laubier, L., and Smith, J.L. Jr, eds., 1983, Hydrothermal processes at seafloor spreading centers: Proceedings of a NATO Advanced Research Institute April 5-8, 1982, NATO Conference Series IV, Marine Sciences, v. 12: New York, Plenum Press, 796 p.

Rona, P.A., Klinkhammer, G., Nelsen, T.A., Trefry, J.H., and Elderfield, H., 1986, Black smokers, massive sulfides and vent biota at the Mid-Atlantic Ridge: Nature, v. 321, p. 33-37.

Rona, P.A., Widenfalk, L., and Botröm, K., 1987, Serpentinized ultramafics and hydrothermal activity at the Mid-Atlantic Ridge crest near $15^{\circ} \mathrm{N}$ : Journal of Geophysical Research, v. 92, p. 1417-1427.

Rona, P.A., Hannington, M.D., Raman, C.V., Thompson, G., Tivey, M.K. Humphris, S.E., Lalou, C., and Petersen, S., 1993a, Active and relict seafloor hydrothermal mineralization at the TAG hydrothermal field, Mid-Atlantic Ridge: ECONOMIC GEOLOGY, v. 88, p. 1989-2017.

Rona, P.A., Bogdanov, Y.A., Gurvich, E.G., Rimski-Korsakov, N.A., Sagalevitch, A.M., and Hannington, M.D., 1993b, Relict hydrothermal zones in the TAG hydrothermal field, Mid-Atlantic Ridge, $26^{\circ} \mathrm{N}, 45^{\circ} \mathrm{W}$ : Journal of Geophysical Research, v. 98, p. 9715-9730.

Rosenbauer, R.J., Bischoff, J.L., and Radtke, A.S., 1983, Hydrothermal alteration of graywacke and basalt by $4 m \mathrm{NaCl}$ : ECONOMIC GEOLOGY, v. 78, p. $1701-1710$.

Sakai, H., Gamo, T., Kim, E-S., Tsutsumi, M., Tanaka, T., Ishibashi, J., Wakita H., Yamano, M., and Oomori, T., 1990, Venting of carbon dioxide-rich fluid 
and hydrate formation in mid-Okinawa trough backarc basin: Science, v. 248 , p. 1093-1096.

Schmidt, R., and Schmincke, H.U., 2000, Seamounts and island building, in Sigurdsson, H., Houghton, B.F., McNutt, S.R., Rymer, H., Stix, J., and Ballard, R.D., eds., Encyclopedia of Volcanoes: San Diego, Academic Press, p. 383-402.

Scholten, J.C., Stoffers, P., Garbe-Schoenberg, D., and Moammar, M., 2000, Hydrothermal mineralization in the Red Sea, in Cronan, D.S., ed., Handbook of marine mineral deposits: Boca Raton, FL, CRC Press, p. 369-395.

Schultz, A., Delaney, J.R., and McDuff, R.E., 1992, On the partitioning of heat flux between diffuse and point source seafloor venting: Journal of Geophysical Research, v. 97, p. 12,299-12,314.

Scott, S.D., 1997, Submarine hydrothermal systems, in Barnes, H.L., ed., Geochemistry of hydrothermal ore deposits, 3rd ed.: New York, NY, John Wiley and Sons, p. 797-875.

Scott, S.D., and Binns, R.A., 1995, Hydrothermal processes and contrasting styles of mineralization in the western Woodlark and eastern Manus basins of the western Pacific: Geological Society of London Special Publication 87, p. 191-206.

Sedwick, P.N., McMurtry, G.M., and MacDougal, J.D., 1992, Chemistry of hydrothermal solutions from Pele's vents, Loihi seamount, Hawaii: Geochimica et Cosmochimica Acta, v. 56, p. 3643-3667.

Seewald, J.S., Seyfried, W.E., Jr., and Thornton, E.C., 1990, Organic-rich sediment alteration: An experimental and theoretical study at elevated temperatures and pressures: Applied Geochemistry, v. 5, p. 193-209.

Seewald, J.S., Seyfried, W.E., Jr., and Shanks, W.C., III., 1994, Variations in the chemical and stable isotope composition of carbon and sulfur species during organic-rich sediment alteration: An experimental and theoretical study of hydrothermal activity at Guaymas basin, Gulf of California: Geochimica et Cosmochimica Acta, v. 58, p. 5065-5082.

Seyfried, W.E., 1987, Experimental and theoretical constraints on hydrothermal alteration processes at mid-ocean ridges: Annual Review of Earth and Planetary Science, v. 15, p. 317-335.

Seyfried, W.E., Jr., and Ding, K.,1995, Phase equilibria in subseafloor hydrothermal systems: A review of the role of redox, temperature, $\mathrm{pH}$ and dissolved $\mathrm{Cl}$ on the chemistry of hot spring fluids at mid-ocean ridges: Geophysical Monograph 91, p. 248-272.

Seyfried W.E., Jr., Ding, K., and Berndt, M.E., 1991, Phase equilibria constraints on the chemistry of hot spring fluids at mid-ocean ridges: Geochimica et Cosmochimica Acta, v. 55, p. 3559-3580.

Seyfried, W.E., Jr., Ding, K., Berndt, M.E., and Chen, X., 1999, Experimental and theoretical controls on the composition of mid-ocean ridge hydrothermal fluids: Reviews in Economic Geology, v. 8, p. 181-200.

Seyfried, W.E., Jr., Seewald, J.S., Berndt, M.E., Ding, K., and Foustoukos, D.I., 2003, Chemistry of hydrothermal vent fluids from the Main Endeavour Field, northern Juan de Fuca Ridge: Geochemical controls in the aftermath of June 1999 seismic events: Journal of Geophysical Research, v. 108, 2429, 16 September, DOI10.1029/2002JB001957, 23 p.

Shanks, W.C., III, 2001, Stable isotopes in seafloor hydrothermal systems: Reviews in Mineralogy, v. 43, p. 469-526.

Shanks, W.C., III, and Bischoff, J.L., 1980, Geochemistry, sulfur isotope composition, and accumulation rates of Red Sea geothermal deposits: EcONOMIC GEOLOGY, v. 75, p. 445-459.

Shanks, W.C., III, Bohlke, J.K., and Seal, R.R., II, 1995, Stable isotopes in midocean ridge hydrothermal systems: interactions between fluids, minerals, and organisms: American Geophysical Union Monograph 91, p. 194-221.

Shinjo, R., and Kato, Y., 2000, Geochemical constraints on the origin of bimodal magmatism at the Okinawa trough, and incipient back-arc basin: Lithos, v. 54, p. 117-137.

Sibuet, J.-C., Hsu, S.-K., Shyu, C.-T., and Liu, C.-S., 1995, Structural and kinematic evolution of the Okinawa trough backarc basin, in Taylor, B., ed., Backarc basins: Tectonics and magmatism: New York, Plenum Press, p. 347-378.

Sibuet, J.-C., Deffontaines, B., Hsu, S.-K., Thareau, N., Le Formel, J.-P., and Lui, C.-S., 1998, Okinawa trough back-arc basin: Early tectonic and magmatic evolution: Journal of Geophysical Research, v. 103, p. 30,245-30,267.

Sigurdsson, H., 2000, Volcanic episodes and rates of volcanism, in Sigurdsson, H., Houghton, B.F., McNutt, S.R., Rymer, H., Stix, J., and Ballard, R.D., eds., Encyclopedia of volcanoes: San Diego, Academic Press, p. 271-279.

Sillitoe, R.H., 1980, Are porphyry copper and kuroko-type massive sulfide deposits incompatible?: Geology, v. 8, p. 11-14.

Sillitoe, R.H., Hannington, M.D., and Thompson, J.F.H., 1996, High-sulfidation deposits in the volcanogenic massive sulfide environment: ECONOMIC GEOLOGY, v. 91, p. 204-212.
Simoneit, B.R.T., and Gize, A.P., 2000, Submarine and continental hydrothermal systems - a review of organic matter alteration and migration processes and comparison with conventional sedimentary basins: Reviews in Economic Geology, v. 9, p. 193-215.

Singer, D.A., 1995, World-class base and precious metal deposits; A quantitative analysis: ECONOMIC GEOLOGY, v. 90, p. 88-104.

Sinha, M.C., Navin, D.A., MacGregor, L.M., Constable, S., Peirce, C., White, A., Heinson, G., and Inglis, M.A., 1999, Evidence for accumulated melt beneath the slow-spreading Mid-Atlantic Ridge, in Cann, J.R., Elderfield, H., and Laughton, A., eds., Mid-ocean ridges: Cambridge, U.K., Cambridge University Press, p. 17-38.

Sinton, J.M., Ford, L.L., Chappell, B., and McCulloch, M.T., 2003, Magma genesis and mantle heterogeneity in the Manus back-arc basin, Papua New Guinea: Journal of Petrology, v. 44, p. 159-195.

Smith, D.K., Tivey, M.A., Schouten, H., and Cann, J.R., 1999, Locating the spreading axis along $80 \mathrm{~km}$ of the Mid-Atlantic Ridge south of the Atlantis transform: Journal of Geophysical Research, v. 104, p. 7599-7612.

Smith, I.E.M., Worthington, T.J., Stewart, R.B., Price, R.C., and Gamble, J.A., 2003, Felsic volcanism in the Kermadec arc, SW Pacific: Crustal recycling in an oceanic setting: Geological Society of London Special Publication 219, p. 99-118.

Sours-Page, R., Johnson, K.T.M., Nielsen, R.L., and Karsten, J.L., 1999 , Local and regional variation of MORB parent magmas: Evidence from melt inclusions from the Endeavour Segment of the Juan de Fuca Ridge: Contributions to Mineralogy and Petrology, v. 134, p. 342-363.

Spiess, F.N., Macdonald, K.C., Atwater, T., Ballard, R., Carranza, A., Cordoba, D., Cox, C., Diaz Garcia, V.M., Francheteau, J., Guerrero, J., Hawkins, J., Haymon, R., Hessler, R., Juteau, T., Kastner, M., Larson, R., Luyendyk, B., Macdougall, J.D., Miller, S., Normark, W., Orcutt, J., Rangin, C., 1980, East Pacific Rise: Hotsprings and geophysical experiments: Science, v. 207, p. 1421-1433.

Stakes, D.S., and Moore, W.S., 1991, Evolution of hydrothermal activity on the Juan de Fuca Ridge: Observations, mineral ages, and Ra isotope ratios: Journal of Geophysical Research, v. 96, p. 12,739-12,752.

Stanton, R.L., 1994, Ore elements in arc lavas: Oxford Monographs on Geology and Geophysics 29, 391 p.

Staudigel, H., Hart, S.R., Kopper, A.A.P., Constable, C., Workman, R., Kurz, M., and Baker, E.T., 2004, Hydrothermal venting at Vailulu'u Seamount: The smoking end of the Samoan chain: Geochemistry, Geophysics, Geosystems, v. 5,25 p.

Stein, C.A., and Stein, S., 1994, Constraints on hydrothermal heat flux through the oceanic lithosphere from global heat flow: Journal of Geophysical Research, v. 99, p. 3081-3095.

Stern, R.J., and Amira, M., 1998, Special issue on geophysical and geochemical studies of the Izu-Bonin-Mariana arc system: Island Arc, v. 7, p. 295-607.

Stern, R.J., and Bloomer, S.H., 1992, Subduction zone infancy; examples from the Eocene Izu-Bonin-Mariana and Jurassic California arcs: Geological Society of America Bulletin, v. 104, p. 1621-1636.

Stern, R.J., Lin, P.N., Morris, J.D., Jackson, M.C., Fryer, P., Bloomer, S.H., and Ito, E., 1990, Enriched back-arc basin basalts from the northern Mariana trough: Implications for the magmatic evolution of back-arc basins: Earth and Planetary Science Letters, v. 100, p. 210-225.

Stoffers, P., Glasby, G.P., Stueben, D., Renner, R.M., Pierre, T.G., Webb, J. and Cardile, C.M., 1993, Comparative mineralogy and geochemistry of hydrothermal iron-rich crusts from the Pitcairn, Teahitia, and Macdonald hot spot areas of the S.W. Pacific: Marine Georesources and Geotechnology, v. 11 , p. $45-86$

Stoffers, P., Hannington, M.D., Wright, I., Herzig, P., and de Ronde, C., 1999, Elemental mercury at submarine hydrothermal vents in the Bay of Plenty, Taupo Volcanic Zone, New Zealand: Geology, v. 27, p. 931-934.

Stueben, D., Bloomer, S.H., Taibi, N.E., Neuman, T., Bendel, V., Pueschel, U., Barone, A., Lange, A., Wu, S., Li, C., and Zhang, D., 1992a, First result of the study of sulphur-rich hydrothermal activity from an island-arc environment: Esmeralda Bank in the Mariana arc: Marine Geology, v. 103, p. $521-528$.

Stueben, D., Stoffers, P., Cheminée, J.-L., Hartman, M., McMurtry, G.M., Richnow, H.H., Jenish, A., and Michaelis, W., 1992b, Manganese, methane, iron, zinc, and nickel anomalies in hydrothermal plumes from Teahitia and Macdonald volcanoes: Geochimica et Cosmochimica Acta, v. 56, p. 3693-3704.

Stueben, D., Neumann, T., Taibi, N.E., and Glasby, G.P., 1995, Variations in hydrothermal activity at the Mariana arc backarc spreading centre at $18^{\circ} 13^{\prime} \mathrm{N}$ between 1987 and 1990: Chemie der Erde, v. 55, p. 61-79.

Taylor, B., ed., 1995, Preface to backarc basins: Tectonics and magmatism New York, Plenum Press, p. ix-xi. 
Taylor, B., and Martinez, F., 2003, Back-arc basin basalt systematics: Earth and Planetary Science Letters, v. 210, p. 481-497.

Taylor, B., Crook, K., and Sinton, J., 1994, Extensional transform zones and oblique spreading centers: Journal of Geophysical Research, v. 99, p. $19,707-19,718$

Taylor, B., Goodliffe, A., Martinez, F., and Hey, R., 1995, Continental rifting and initial sea-floor spreading in the Woodlark basin: Nature, v. 374, p. 534-537.

Taylor, B., Zellmer, K., Martinez, F., and Goodliffe, A.M., 1996, Sea-floor spreading in the Lau back-arc basin: Earth and Planetary Science Letters, v. 144 , p. $35-40$.

Teagle, D.A.H., and Alt, J.C., 2004, Hydrothermal alteration of basalts beneath the Bent Hill massive sulfide deposit, Middle Valley, Juan de Fuca Ridge: Economic Geology, v. 99, p. 561-584.

Thornton, E.C., and Seyfried, W.E., Jr., 1987, Reactivity of organic-rich sediment in seawater at $350^{\circ} \mathrm{C}, 500$ bars: Experimental and theoretical constraints and implications for the Guaymas basin hydrothermal system: Geochimica et Cosmochimica Acta, v. 51, p. 1997-2010.

Tivey, M.K., Stakes, D.S., Cook, T.L., Hannington, M.D., and Petersen, S., 1999, A model for growth of steep-sided vent structures on the Endeavour Segment of the Juan de Fuca Ridge: Results of a petrologic and geochemical study: Journal of Geophysical Research, v. 104, p. 22,859-22,883.

Trefry, J.H., Butterfield, D.B., Metz., S., Massoth, G.J., Trocine, R.P., and Feely, R.A., 1994, Trace metals in hydrothermal solutions from Cleft segment on the southern Juan de Fuca Ridge: Journal of Geophysical Research, v. 99, p. 4925-4936.

Tsunogai, U., Ishibashi, J., Wakita, H., Gamo, T., Watanabe, K., Kajimura, T., Kanayama, S., and Sakai, H., 1994, Peculiar features of Suiyo Seamount hydrothermal fluids, Izu-Bonin arc: Differences from subaerial volcanism: Earth and Planetary Science Letters, v. 126, p. 289-301.

Tucholke, B.E., and Lin, J., 1994, A geological model for the structure of ridge segments in slow-spreading ocean crust: Journal of Geophysical Research, v. 99, p. 11,937-11,958.

Ueda, A., and Sakai, H., 1984, Sulfur isotope study of Quaternary volcanic rocks from the Japanese island arc: Geochimica et Cosmochimica Acta, v. 48 , p. $1837-1848$

Urabe, T., and Kusakabe, M., 1990, Barite-silica chimneys from the Sumisu rift, Izu-Bonin back-arc: Possible analog to hematitic chert associated with Kuroko deposits: Earth and Planetary Science Letters, v. 100, p. 283-290.

Urabe, T., Baker, E.T., Ishibashi, I., Feely, R.A., Marumo, K., Massoth, G.J., Maruyama, A., Shitashima, K., Okamura, K., Lupton, J.E., Sonoda, A., Yamazaki, T., Aoki, M., Gendron, J., Greene, R., Kaiho, Y., Kisimoto, K., Lebon, G., Matsumoto, T., Nakamura, K., Nishizawa, A., Okano, O., Paradis, G., Roe, K., Shibata, T., Tennant, D., Vance, T., Walker, S.L., Yabuki, T., and Ytow, N., 1995, The effect of magmatic activity on hydrothermal venting along the superfast-spreading East Pacific Rise: Science, v. 269, p. 1092-1095.

Vanko, D.A., Griffith, J.D., and Erickson, C.L., 1992, Calcium-rich brines and other hydrothermal fluids in fluid inclusions from plutonic rocks, Oceanographer Transform, Mid-Atlantic Ridge: Geochimica et Cosmochimica Acta, v. 56, p. $35-47$.

Van Kranendonk, M.J., Hickman, A.H., Smithies, R.H., Nelson, G., and Pike, G., 2002, Geology and tectonic evolution of the Archean North Pilbara terrane, Pilbara craton, Western Australia: Economic Geology, v. 97, p. 695-732.

Varnavas, S.P., and Cronan, D.S., 1991, Hydrothermal metallogenic processes off the islands of Nissiros and Kos in the Hellenic volcanic arc: Marine Geology, v. 99, p. 109-133

Vera, E.E., and Diebold, J.B., 1994, Seismic imaging of oceanic layer 2A between $9^{\circ} 30^{\prime} \mathrm{N}$ and $10^{\circ} \mathrm{N}$ on the East Pacific Rise from two-ship, wide-aperture profiles: Journal of Geophysical Research, v. B99, p. 3031-3041.

Von Damm, K.L., 1988, Systematics of and postulated controls on submarine hydrothermal solution chemistry: Journal of Geophysical Research, v. 93, p. $4551-4561$.

1990, Seafloor hydrothermal activity: Black smoker chemistry and chimneys: Annual Review of Earth and Planetary Sciences, v. 18, p. 173-204.

1991, A comparison of Guaymas basin hydrothermal solutions with other sedimented systems and experimental results: American Association of Petroleum Geologists Memoir 47, p. 743-751.

2000 , Chemistry of hydrothermal vent fluids from $9^{\circ}-10^{\circ} \mathrm{N}$, East Pacific Rise: "Time zero," the immediate posteruptive period: Journal of Geophysical Research, v. 105, p. 11,203-11,222.

Von Damm, K.L., and Bischoff, J.L., 1987, Chemistry of hydrothermal solutions from the southern Juan de Fuca Ridge: Journal of Geophysical Research, v. 92, p. 11,334-11,346.
1991, Quartz solubility in hydrothermal seawater: An experimental study and equation describing quartz solubility for up to $0.5 \mathrm{M} \mathrm{NaCl}$ solutions: American Journal of Science, v. 291, p. 977-1007.

Von Damm, K.L., Edmond, J.M., Grant, B., and Measures, C.I., 1985a, Chemistry of submarine hydrothermal solutions at $21^{\circ} \mathrm{N}$, East Pacific Rise: Geochimica et Cosmochimica Acta, v. 49, p. 2197-2220.

Von Damm, K.L., Edmond, J.M., Measures, C.I., and Grant, B., 1985b, Chemistry of submarine hydrothermal solutions at Guaymas Basin, Gulf of California: Geochimica et Cosmochimica Acta, v. 49, p. 2221-2237.

Von Damm, K.L., Buttermore, L.G., Oosting, S.E., Bray, A.M., Fornari, D.J., Lilley, M.D., and Shanks, W.C., III, 1997, Direct observation of the evolution of a seafloor "black smoker" from vapor to brine: Earth and Planetary Science Letters, v. 149, p. 101-111.

Wallace, P.J., 2003, From mantle to atmosphere: Magma degassing, explosive eruptions, and volcanic volatile budgets: Developments in Volcanology 5, p. $105-127$

Watanabe, K., and Kajimura, T., 1994, The hydrothermal mineralization at Suiyo seamount, Izu-Ogasawara arc: Resource Geology, v. 44, p. 133-140 (in Japanese).

Welhan, J.A. 1988, Origins of methane in hydrothermal systems: Chemical Geology, v. 71, p. 183-198.

Wetzel, L.R., and Shock, E.L., 2000, Distinguishing ultramafic from basalthosted submarine hydrothermal systems by comparing calculated vent fluid compositions: Journal of Geophysical Research, v. 105, p. 8319-8340.

White, R.S., 1999, Rift-plume interaction in the North Atlantic, in Cann, J.R., Elderfield, H., and Laughton, A., eds., Mid-ocean ridges: Cambridge, U.K., Cambridge University Press, p. 103-124.

Wilcock, W.S.D., Archer, S.D., and Purdy, G., 2002, Microearthquakes on the Endeavour segment of the Juan de Fuca Ridge: Journal of Geophysical Research, v. 107, p. 12.

Wright, I.C., 1992, Shallow structure and active tectonism of an offshore continental back-arc spreading system: The Taupo Volcanic Zone, New Zealand: Marine Geology, v. 103, p. 287-309.

Wright, I.C., and Gamble, J.A., 1999, Southern Kermadec submarine caldera arc volcanoes (SW Pacific): Caldera formation by effusive and pyroclastic eruption: Marine Geology, v. 161, p. 209-229.

Wright, I.C., de Ronde, C.E.J., Faure, K., and Gamble, J.A., 1998, Discovery of hydrothermal sulfide mineralization from southern Kermadec arc volcanoes (SW Pacific): Earth and Planetary Science Letters, v. 164, p. 335-343.

Wright, I.C., Stoffers, P., Hannington, M., de Ronde, C.E.J, Herzig, P, Smith, I.E.M., and Browne, P.R.L., 2002, Towed-camera investigations of shallowintermediate water-depth submarine basaltic stratovolcanoes of the southern Kermadec arc, New Zealand: Marine Geology, v. 185, p. 207-218.

Yang, K., and Scott, S.D., 1996, Possible contribution of a metal-rich magmatic fluid to a seafloor hydrothermal system: Nature, v. 383, p. 420-423.

2002, Magmatic degassing of volatiles and ore metals into a hydrothermal system on the modern sea floor of the Eastern Manus back-arc basin, Western Pacific: Economic Geology, v. 97, p. 1079-1100.

Yuasa, M., Murakami, F., Saito, E., and Watanabe, K., 1991, Submarine topography of seamounts on the volcanic front of the Izu-Ogasawara (Bonin) arc: Bulletin of the Geological Survey of Japan, v. 42, p. 703-743.

Zierenberg, R.A., 1994, Sulfur content of sediments and sulfur isotope values of sulfide and sulfate minerals from Middle Valley: Proceedings of the Ocean Drilling Program, Scientific Results, v. 139, p. 739-748.

Zierenberg, R.A., and Miller, D.J., 2000, Overview of Ocean Drilling Program Leg 169: Sedimented ridges II: Proceedings of the Ocean Drilling Program, Scientific Results, v. 169, p. 1-39.

Zierenberg, R.A., and Shanks, W.C., 1983, Mineralogy and geochemistry of epigenetic features in metalliferous sediment, Atlantis II Deep, Red Sea: ECONOMIC GEOLOGY, v. 78, p. 57-72.

1986, Isotopic constraints on the origin of the Atlantis II, Suakin and Valdivia brines, Red Sea: Geochimica et Cosmochimica Acta, v. 50, p. 2205-2214.

Zierenberg, R.A., Koski, R.A., Morton, J.L., Bouse, R.M., and Shanks, W.C. III., 1993, Genesis of massive sulfide deposits on a sediment-covered spreading center, Escanaba trough, southern Gorda Ridge: EcONOMIC GEOLOGY, v. 88, p. 2069-2098.

Zierenberg, R.A., Morton, J.L., Koski, R., and Ross, S.L., 1994, Geologic setting of massive sulfide mineralization in Escanaba trough: U.S. Geological Survey Bulletin 2022, p. 171-200.

Zierenberg, R.A., Fouquet, Y., Miller, J., and Shipboard Scientific Party, 1998, The deep structure of a seafloor hydrothermal deposit: Nature, v. 392 , p. $485-488$. 

Supplement to

Sea-Floor Tectonics and Submarine Hydrothermal Systems

Mark D. Hannington, Cornel E. J. De Ronde, and Sven Petersen 


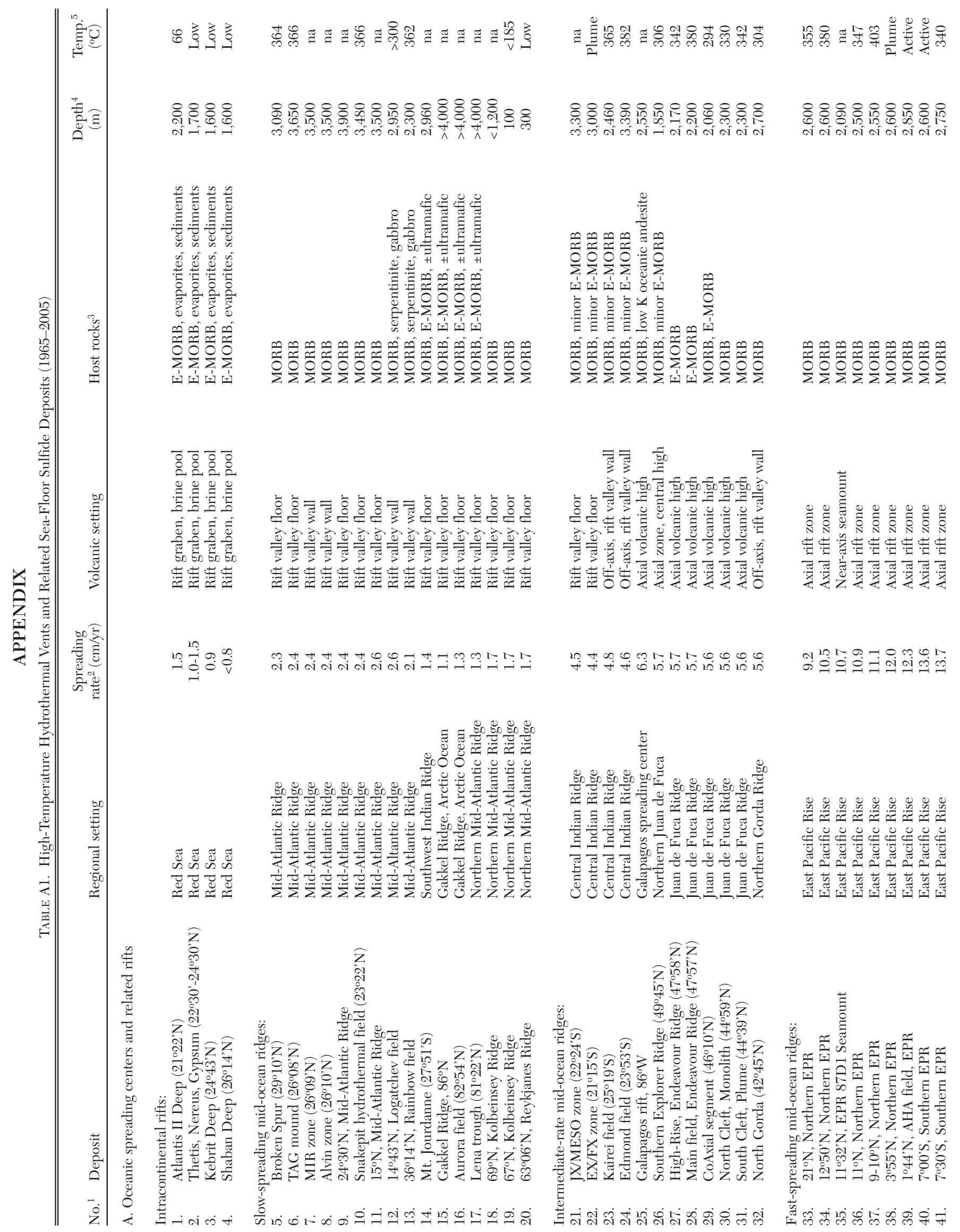




\begin{tabular}{|c|c|c|c|c|c|c|c|c|}
\hline : & 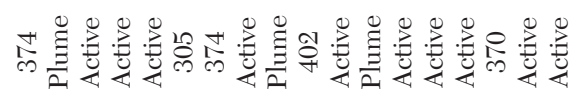 & $\dddot{̋} \cong||$ & 놋농ํำ & $\frac{12}{m}$ & 恶品芯 & \multicolumn{2}{|l|}{$\stackrel{\leftrightarrow}{\mathrm{I}}$} & 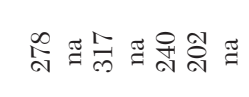 \\
\hline t: & 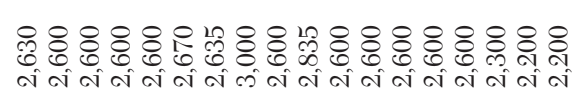 & 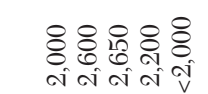 & 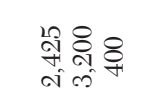 & $\underset{8}{8}$ & 윰옹 & \multicolumn{2}{|l|}{$\stackrel{8}{\infty}$} & 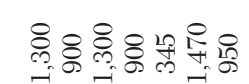 \\
\hline 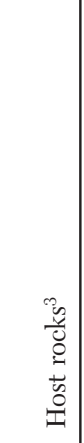 & 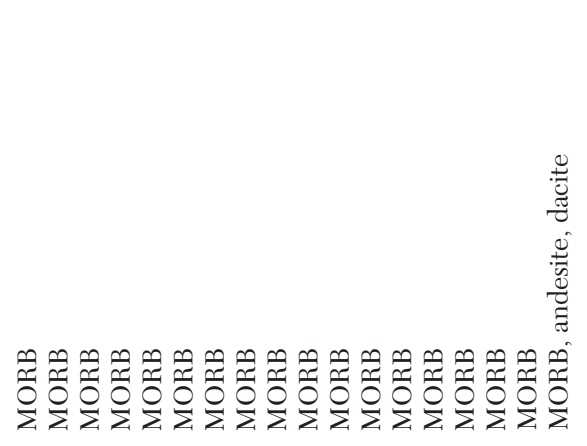 & 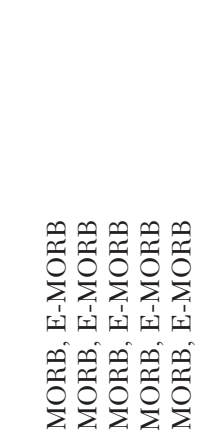 & 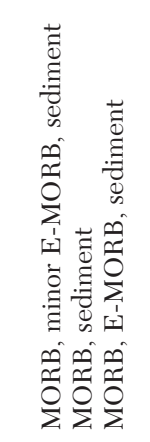 & 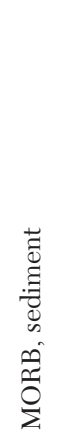 & 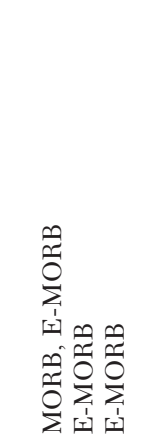 & \multicolumn{2}{|l|}{$\cong$} & 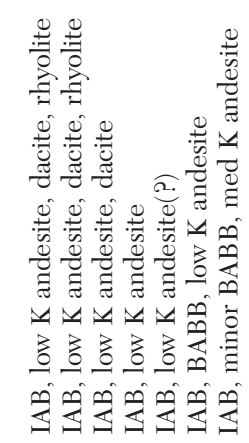 \\
\hline 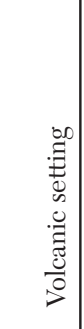 & 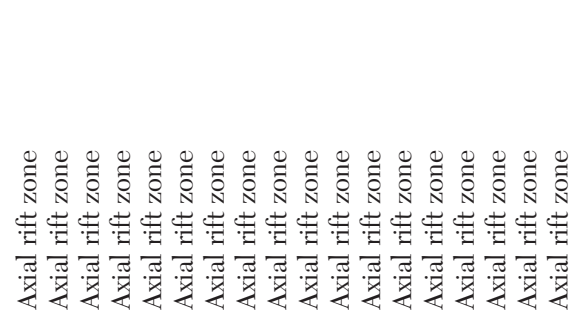 & 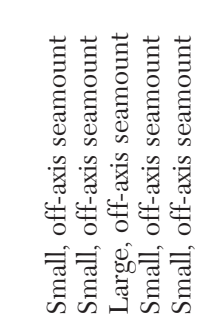 & 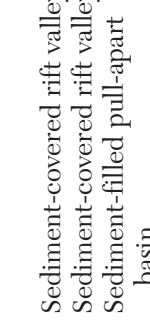 & 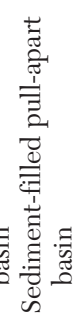 & 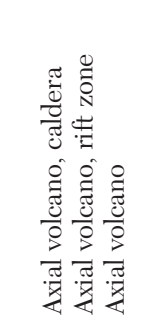 & $\begin{array}{l}0 \\
\text { है } \\
0 \\
0 \\
0 \\
0 \\
0 \\
0 \\
0 \\
0\end{array}$ & & 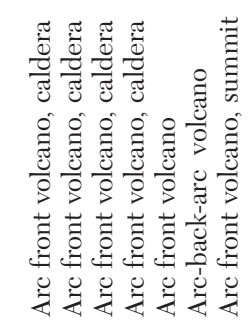 \\
\hline 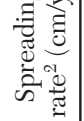 & 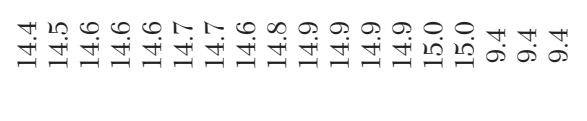 & 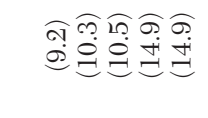 & 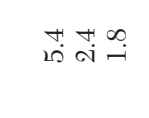 & $\stackrel{\infty}{\infty}$ & 욤 & $\dddot{g}$ & & 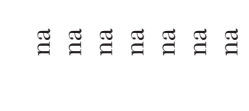 \\
\hline 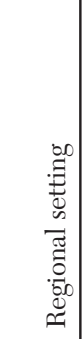 & 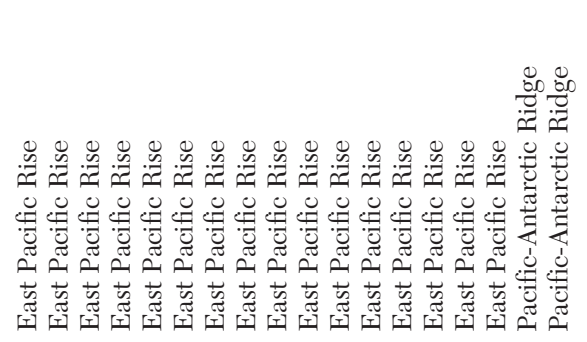 & 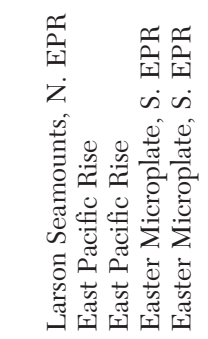 & 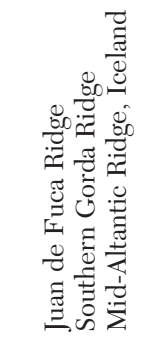 & 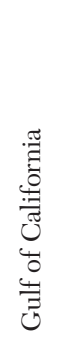 & 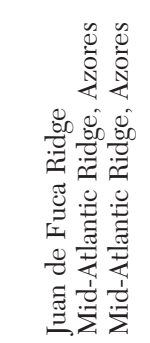 & 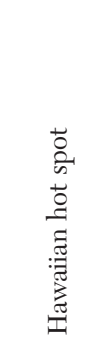 & & 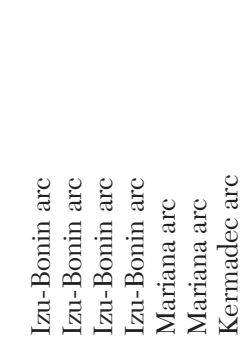 \\
\hline $\begin{array}{l}\overrightarrow{\overrightarrow{0}} \\
0 \\
\stackrel{0}{0} \\
\stackrel{0}{0}\end{array}$ & 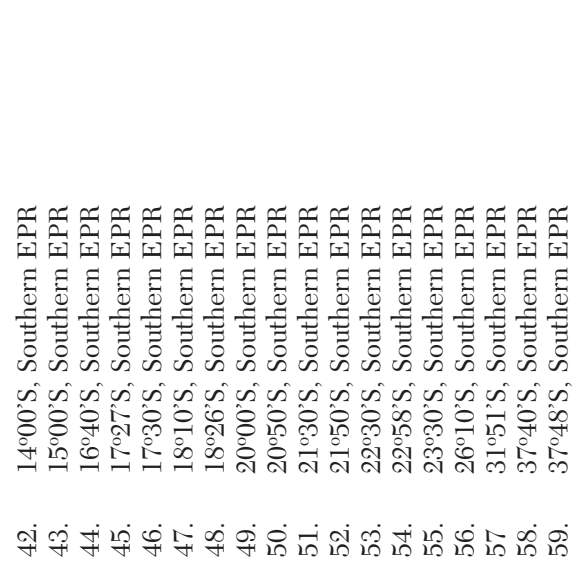 & 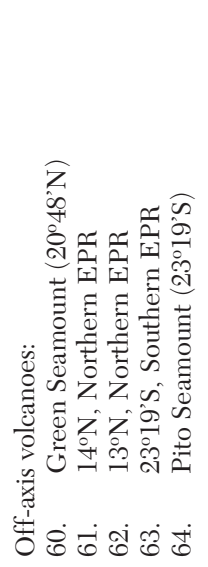 & 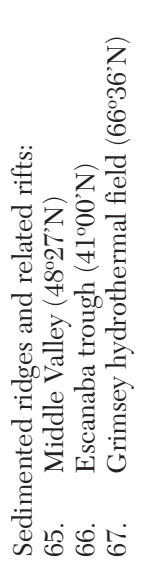 & 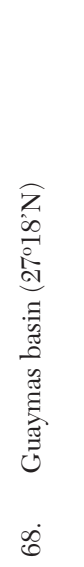 & 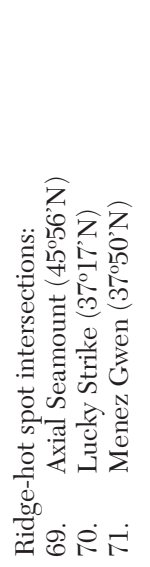 & 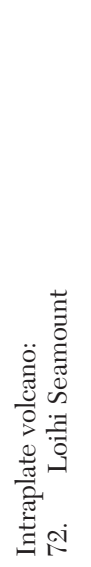 & 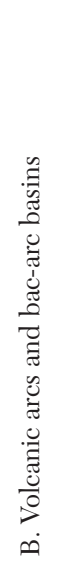 & 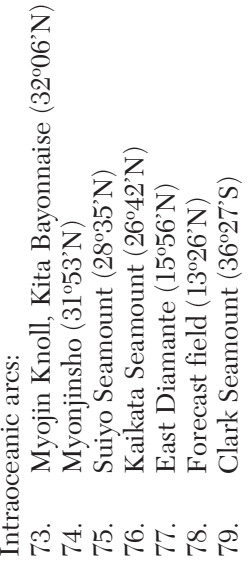 \\
\hline
\end{tabular}




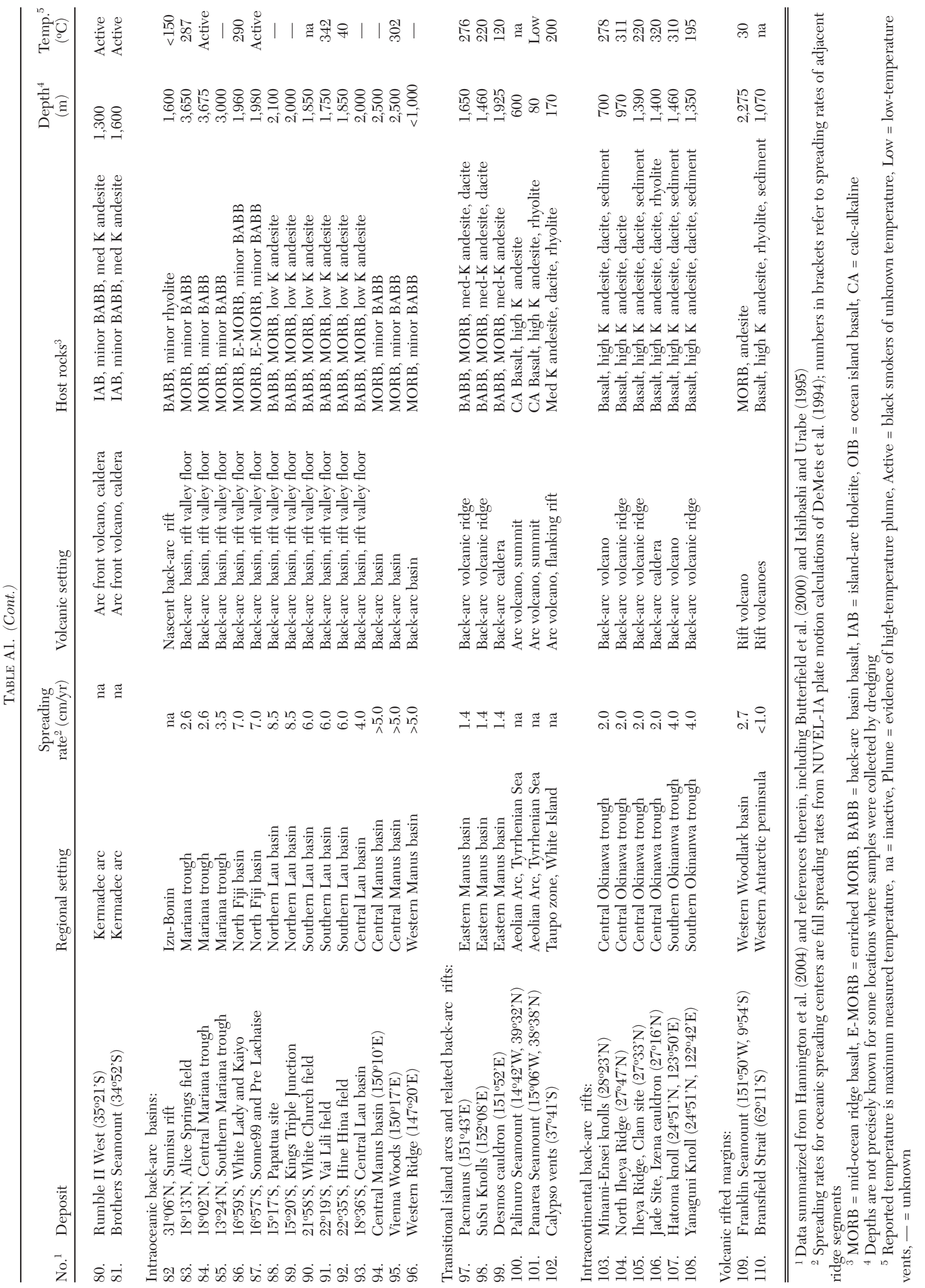




\section{REFERENCES}

Butterfield, D.A., 2000, Deep ocean hydrothermal vents, in Sigurdsson, H., Houghton, B.F., McNutt, S.R., Rymer, H., Stix, J., and Ballard, R.D., eds., Encyclopedia of volcanoes: San Diego, CA, Academic Press, p. 857-875.

DeMets, C., Gordon, R.G., Argus, D.F., and Stein, S., 1994, Effect of recent revisions to the geomagnetic reversal time scale on estimates of current plate motions: Geophysical Research Letters, v. 21, p. 2191-2194.
Hannington, M.D., Petersen, S., Herzig, P.M., and Jonasson, I.R., 2004, A global database of seafloor hydrothermal systems, including a digital database of geochemical analyses of seafloor polymetallic sulfides: Geological Survey of Canada Open File 4598 (CD-ROM).

Ishibashi, J., and Urabe, T., 1995, Hydrothermal activity related to arcbackarc magmatism in the Western Pacific, in Taylor, B., ed., Backarc basins: Tectonics and magmatism: New York, Plenum Press, p. 451-495. 


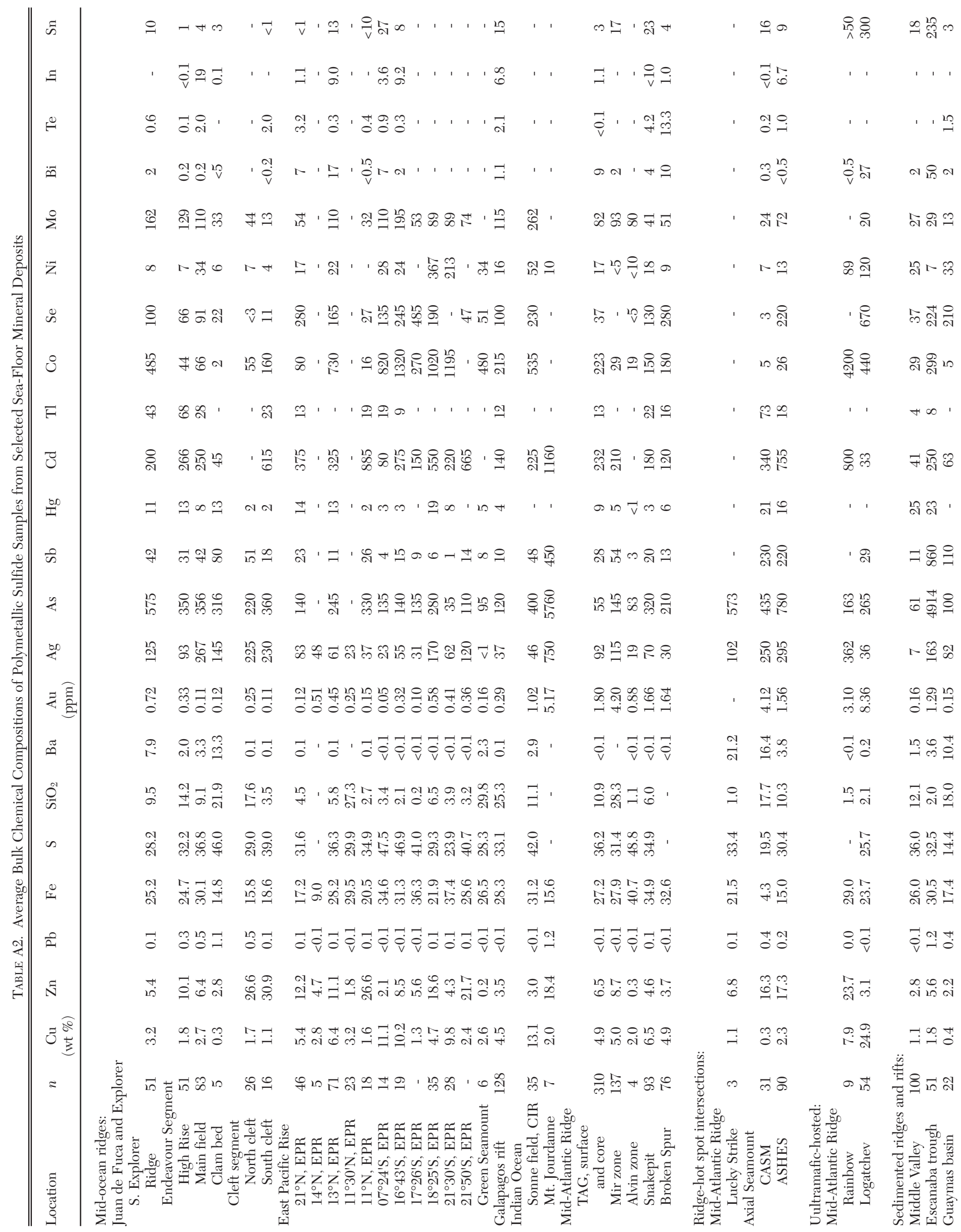




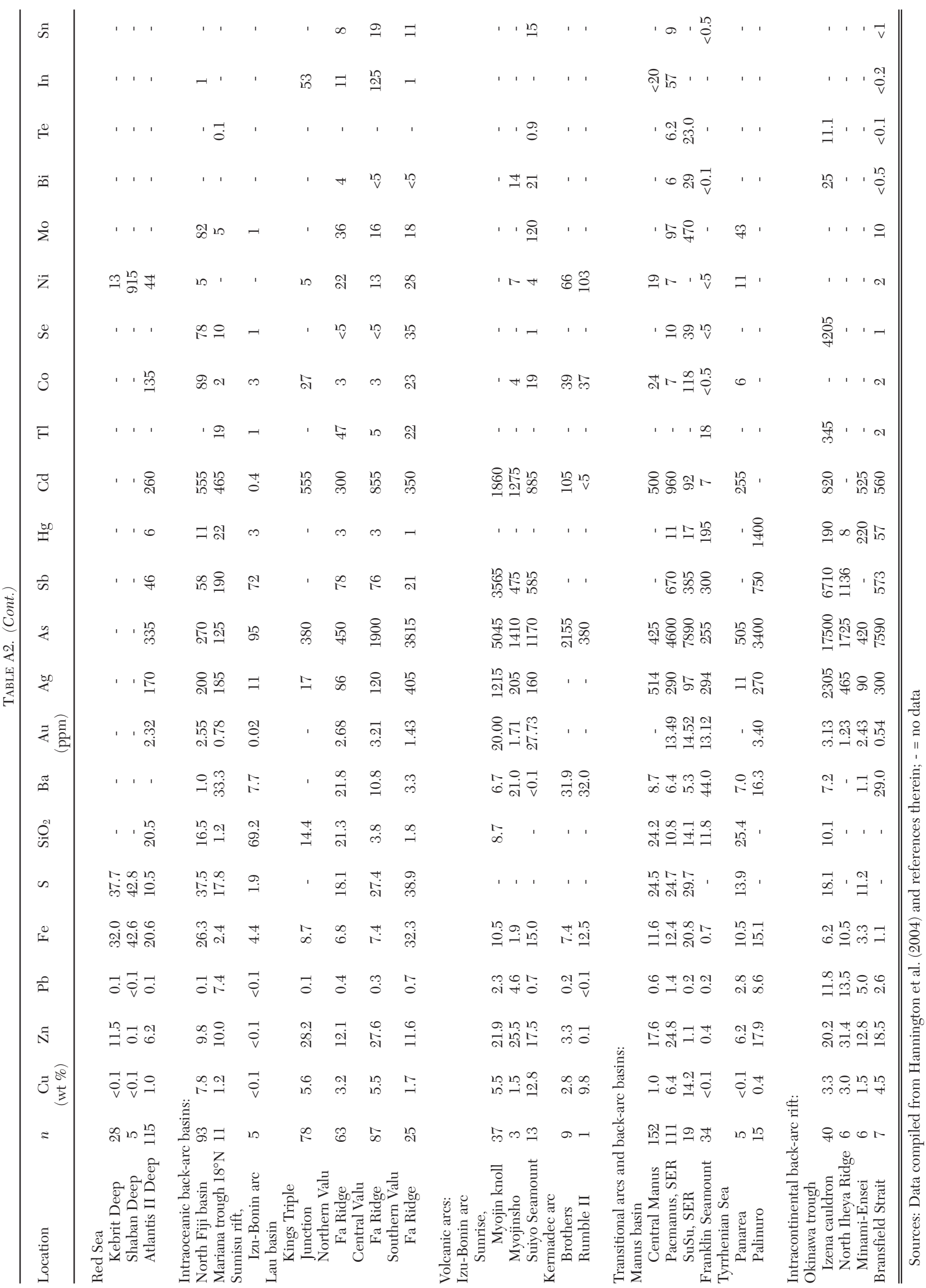




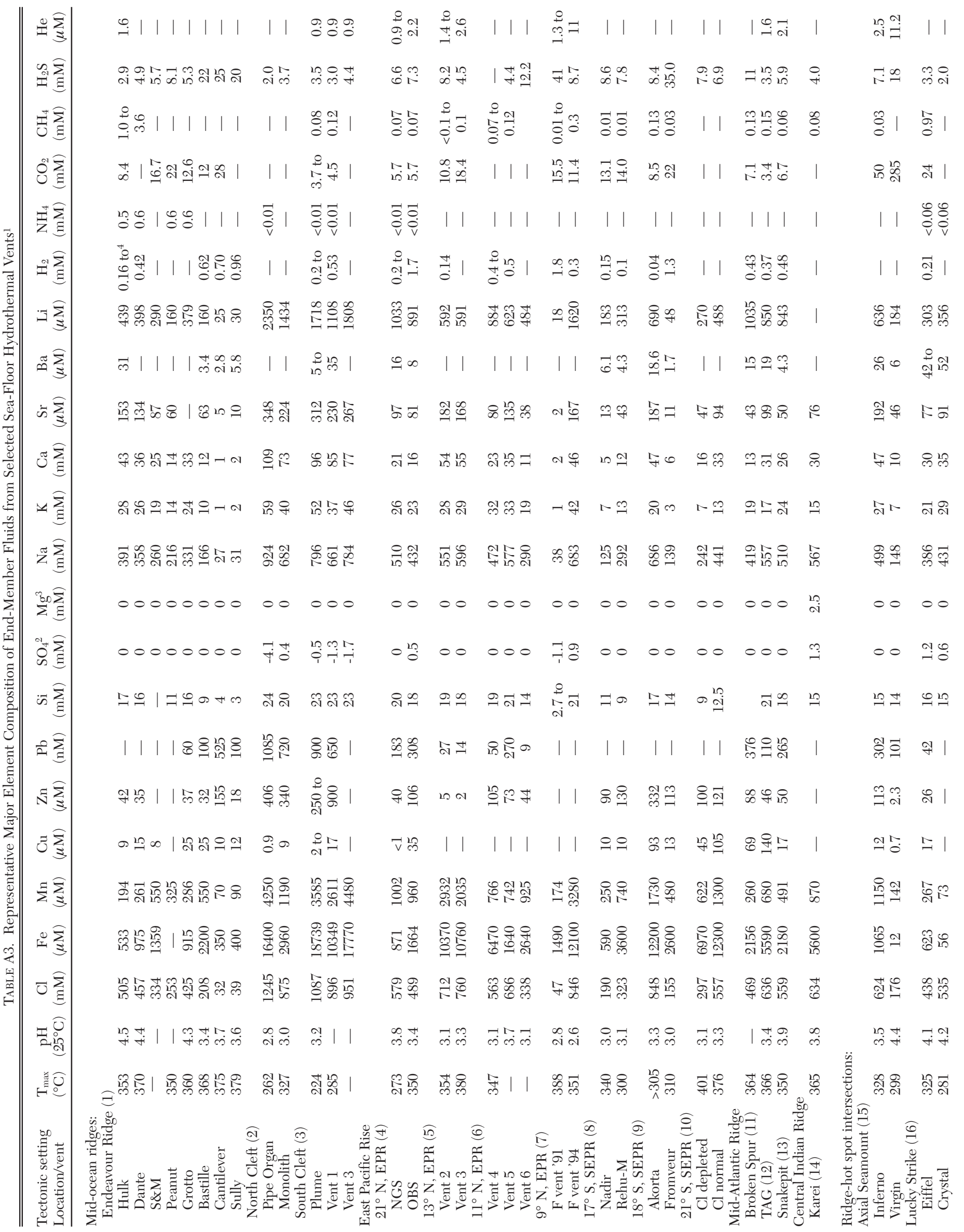




\begin{tabular}{|c|c|c|c|c|c|c|c|c|c|c|c|c|c|c|}
\hline$\stackrel{ \pm}{\underline{\Xi}}$ & I & | | | & | | | & | | | | & 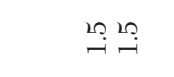 & 11 & I & $\stackrel{m}{\circ} \mid$ & & | | | & $\stackrel{8}{8} 1 \stackrel{1}{0}$ & | 1 & $\stackrel{\text { ồ }}{0}$ & $\bar{z}$ \\
\hline 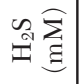 & $\stackrel{\bullet}{-}$ & 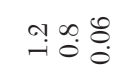 & 車 & 品 | & $\stackrel{i}{i} \stackrel{\circ}{+}$ & | | & in & $\stackrel{\circ}{-} \stackrel{0}{0}$ & & $\stackrel{\infty}{-\infty}$ & $\stackrel{\vec{I}}{a} \mid \stackrel{\vec{j}}{\mathrm{i}}$ & 浐: & $\stackrel{ت}{ت}$ & 芯: \\
\hline है & I & ํํㄱ & | | | & | | | | & $\stackrel{3}{0} \stackrel{0}{0}$ & $\stackrel{\vee}{\vee} \mid$ & 1 & $=\begin{array}{l}7 \\
0\end{array}$ & & $|1|$ & $\stackrel{0}{\stackrel{0}{1}} \mid \stackrel{0}{1}$ & $\mid \stackrel{\substack{n \\
0}}{0}$ & $\stackrel{\check{\Theta}}{=}$ & \\
\hline 己 & ริ & $\stackrel{ }{\circ} 1$ & | | | & $\stackrel{\mathscr{L}}{+} \mid \stackrel{\wedge}{\wedge} \underset{\mathrm{i}}{\mathrm{n}}$ & $\Xi ニ$ & 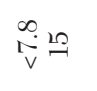 & $\stackrel{\Re}{F}$ & 유 융 & & $0 \stackrel{0}{\circ} 1$ & $\stackrel{\circ}{\stackrel{9}{9}} \mid \stackrel{8}{\circ}$ & 总 & $\stackrel{3}{i}$ & \\
\hline 当 & I & | | | & 总 & $\stackrel{\infty}{\infty i}|\stackrel{0}{i}|$ & | | & | | & $\overrightarrow{\dot{S}}$ & $=1$ & & | | | & 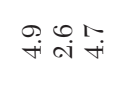 & $\stackrel{\infty}{0}$ & $\overrightarrow{\dot{b}}$ & \\
\hline \pm & $\stackrel{+}{0}$ & O용요 & | | | & | | | | & | | & | 1 & 1 & | | & & | | | & 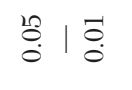 & $\mid 1$ & $\stackrel{ت}{\sharp}$ & \\
\hline$=\frac{2}{3}$ & $\stackrel{R}{\text { I }}$ & 䙲吘 | & 范柴悉 & \&요용 & \&્ণ & 品 & $\underset{\substack{0 \\
\text { 足 }}}{ }$ & $\overbrace{0} \stackrel{9}{9}$ & & 응공 & 离。 & 周 శ్ & $\stackrel{\circ}{\circ}$ & \\
\hline$\check{n}$ & 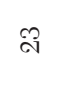 & 苟的। & 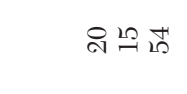 & $\stackrel{2}{2} \mid$ & 010 & $\mathbb{i}_{1} \circ$ & ন্ & $\cong 1$ & & $\asymp \overrightarrow{\dot{\rho}^{\prime}}$ & 옥ำ & | | & $\stackrel{\sharp}{0}$ & \\
\hline$=\sum_{3}$ & 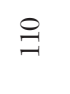 & $\stackrel{\mathscr{g}}{\stackrel{\infty}{9}} \mid$ & 范哭 令 & 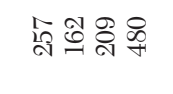 & $\mathscr{\rho} \Re$ & 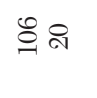 & $\Re$ & \&్ల \& & & 冬히 | & 헝엉 & Sু 1 & 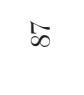 & \\
\hline 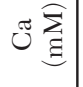 & O잉 & $\sqsubseteq \stackrel{\infty}{\circ} \cong$ & ঞ্ন 강 & 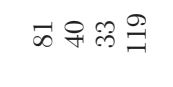 & $r \sigma$ & $\mathscr{\wp} F$ & ন & $\mathscr{D}+$ & & 이요요 & 웍녹 웍 & 윽 & 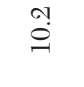 & \\
\hline 4 & 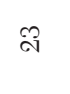 & สণ & 위동ㅇ & 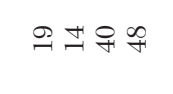 & $=12$ & ర大 & $\vec{\infty}$ & లిం & & ন゙\&ᄋ & 온요 & I 0 & $\infty$ & \\
\hline žs & $\stackrel{m}{m}$ & 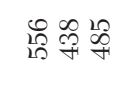 & 总爱路 & 品 & 융 & 闾品 & $\overrightarrow{\mathscr{F}}$ & 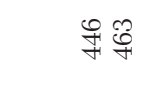 & & 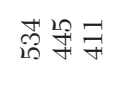 & 品品 & $\ddot{\xi} \vartheta$ & 苍 & \\
\hline ? & o & $00 \frac{9}{9}$ & 000 & $000 \frac{0}{9}$ & 00 & 00 & 0 & $\circ 8$ & & $\neg \circ \mathscr{F}$ & 000 & ing & 송 & \\
\hline $\begin{array}{l}a \\
0 \\
0 \\
0\end{array}$ & o & $00 \underset{0}{\frac{9}{2}}$ & ị: & H:OO & 00 & 00 & 0 & 임 & & $00 \%$ & 000 & 유 & 离 & \\
\hline$=\bar{\Sigma}$ & 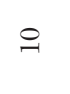 & $n \infty \mid$ & $\stackrel{\Re}{二}$ & $\circ \stackrel{9}{0} \stackrel{0}{0}$ & 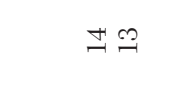 & \pm 2 & \pm & $\stackrel{\infty}{\rightarrow}$ & & 120 & $9 \infty$ & $\stackrel{\infty}{\circ}$ & $\stackrel{9}{\circ}$ & \\
\hline 2 & I & $\stackrel{n}{9} \infty$ & 记 영 & 乲品 $1 \stackrel{8}{\exists}$ & | | & \&: & I & | | & & $+\frac{\vdots}{1} \mid$ & $\infty$ & $\mid 1$ & $\overrightarrow{\dot{a}}$ & 惫: \\
\hline 촠 & $\stackrel{9}{\stackrel{9}{+}}$ & $\stackrel{\infty}{\infty} \mathscr{A}_{\mathbb{N}} \mid$ & 우욤 & 궁 & | | & 亲。 & 1 & | | & & $\therefore \stackrel{10}{=} 1$ & $\infty \mid 1$ & 11 & $\stackrel{\vec{b}}{\dot{v}}$ & \\
\hline $0 \overline{3}$ & 서 & $\stackrel{\mathscr{m}}{9}$ 니 & $\vec{v} \vec{v} \neg$ & $\stackrel{m}{\rightarrow} \stackrel{\infty}{0} \mid \stackrel{m}{0}$ & | | & ○ & I & | | & & ๙ & 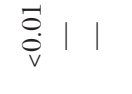 & $\mid 1$ & ڤ̊ & \\
\hline$\sum \widehat{\sum}$ & is & 㐫 & तิ่ & ชำส สํํㄹ & 웍 요 & 융융 & 㞼 & 盛 & & 융 & 㝵学吉 & $\stackrel{\infty}{\infty} \infty$ & 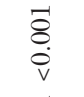 & \\
\hline $0 \widehat{=}$ & 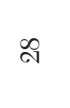 & 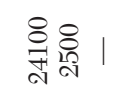 & $\underset{7}{\infty} \underset{\sim}{\infty}$ & 워능요욤 & $\stackrel{20}{2}$ & 裉品 & 0 & 笋。 & & 兑菒| & $n \mid 1$ & 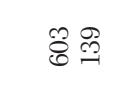 & $\begin{array}{l}\vec{\Xi} \\
\stackrel{\dot{v}}{v}\end{array}$ & \\
\hline U $\widehat{\bar{E}}$ & $\stackrel{\infty}{\circ}$ & 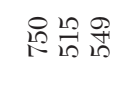 & 总范总 & 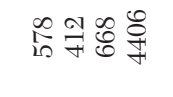 & 总芯 & 욛 & 薄 & $\begin{array}{ll}\infty & 10 \\
8 & 10\end{array}$ & $\ddot{g}$ & 웓웜용 & 员品嗀 & 䇧 $\vec{F}$ & F & \\
\hline & $\stackrel{9}{+}$ & 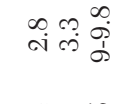 & "ז. & مْ & $\ddot{\ddot{g}} \stackrel{r}{+} \stackrel{r}{\forall}$ & $\mid \stackrel{\circ}{i}$ & $\stackrel{+}{+}$ & ra & 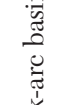 & F⿻ & r & & $\stackrel{\infty}{\stackrel{\infty}{N}}$ & \\
\hline & $\stackrel{+1}{\circ}$ & 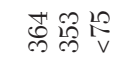 & 공 & 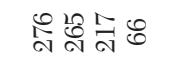 & 胥 & 承 & 总 & స్ & 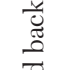 & 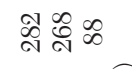 & 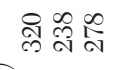 & $\frac{\overrightarrow{\tilde{J}}}{0} \overrightarrow{0} \mid$ & 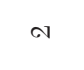 & \\
\hline 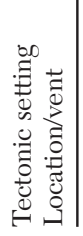 & 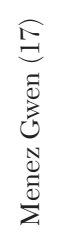 & 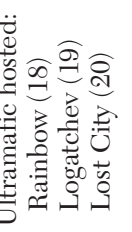 & 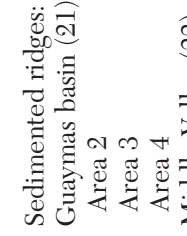 & 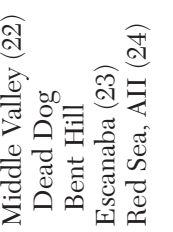 & 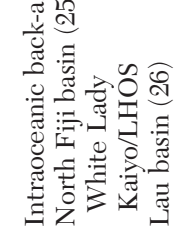 & 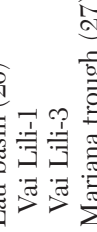 & 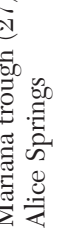 & 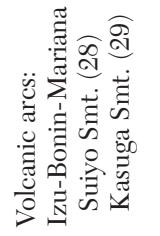 & 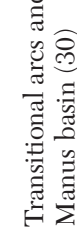 & 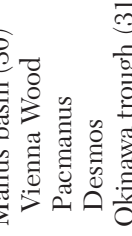 & 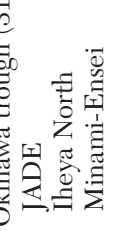 & 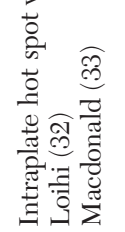 & 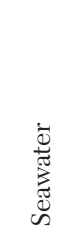 & 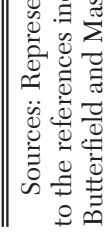 \\
\hline
\end{tabular}




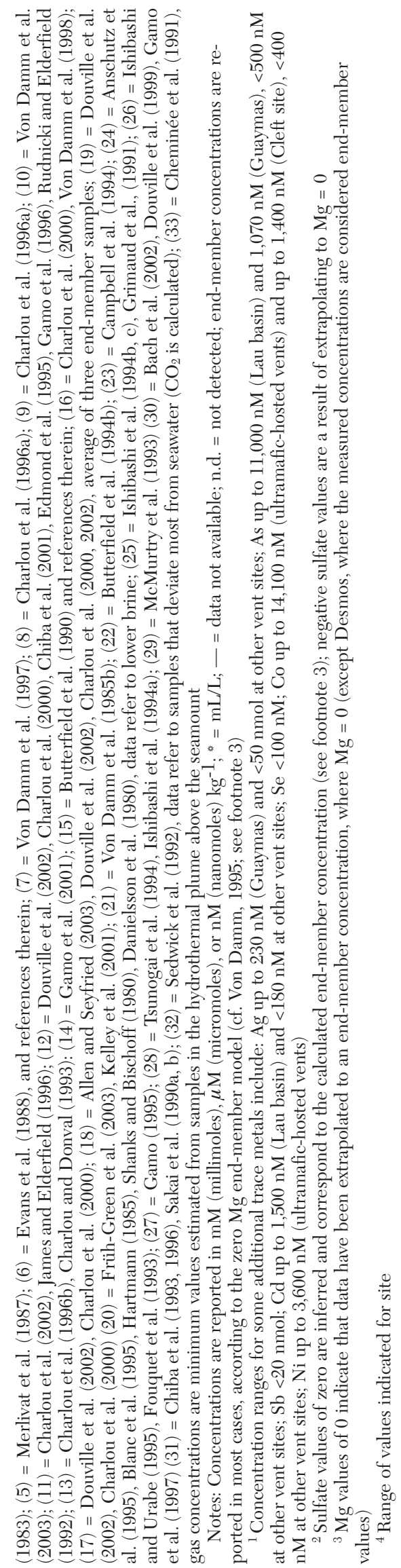

\section{REFERENCES}

Allen, D.A., and Seyfried, W.E., Jr., 2003, Compositional controls on vent fluids from ultramafic-hosted hydrothermal systems at mid-ocean ridges: An experimental study at $400^{\circ} \mathrm{C}, 500$ bars: Geochimica et Cosmochimica Acta, v. 67 , p. $1531-1542$.

Anschutz, P., Blanc, G., and Stille, P., 1995, Origin of fluids and the evolution of the Atlantis II deep hydrothermal system, Red Sea: Strontium isotope study: Geochimica et Cosmochimica Acta, v. 59, p. 4799-4808.

Bach, W., Barriga, F., Binns, R., Roberts, S., Scott, S., Vanko, D., and Yeats, C., 2002, Anatomy of a dacite-hosted submarine hydrothermal system: Results from drilling at PACMANUS [abs.]: Geochemica et Cosmochimica Acta, v. 66, Supplement 15A, p. 41

Blanc, G., Boulegue, J., and Michard, A., 1995, Isotope compositions of the Red Sea hydrothermal end member: Comptes Rendu, Acad. Sci. Paris Serie II, v. 320, p. 1187-1193.

Butterfield, D.A., 2000, Deep ocean hydrothermal vents, in Sigurdsson, H., Houghton, B.F., McNutt, S.R., Rymer, H., Stix, J., and Ballard, R.D., eds., Encyclopedia of volcanoes: San Diego, CA, Academic Press, p. 857-875.

Butterfield, D.A., and Massoth, G.J., 1994, Geochemistry of North cleft segment vent fluids: Temporal changes in chlorinity and their possible relation to recent volcanism: Journal of Geophysical Research, v. 99, p. 4951-4968.

Butterfield, D.A., Massoth, G.J., McDuff, R.E., Lupton, J.E., and Lilley, M.D., 1990, Geochemistry of hydrothermal fluids from ASHES vent field, Juan de Fuca Ridge: Subsea-floor boiling and subsequent fluid-rock interaction: Journal of Geophysical Research, v. 95, p. 12895-12921.

Butterfield, D.A., McDuff, R.E., Mottl, M.J., Lilley, M.D., Lupton, J.E., and Massoth, G.J., 1994a, Gradients in the composition of hydrothermal fluids from Endeavour Ridge vent field: Phase separation and brine loss: Journal of Geophysical Research, v. 99, p. 9561-9583.

Butterfield, D.A., McDuff, R.E., Franklin, J.M., and Wheat, C.G., 1994b, Geochemistry of hydrothermal vent fluids from Middle Valley, Juan de Fuca Ridge: Proceedings of the Ocean Drilling Program, Scientific Results, v. 139 , p. $395-410$.

Campbell, A.C., German, C.R., Palmer, M.R., and Edmond, J.M., 1994, Chemistry of hydrothermal fluids from the Escanaba trough, Gorda Ridge: U.S. Geological Survey Bulletin 2022, p. 201-222.

Charlou, J.L., and Donval, J.P., 1993, Hydrothermal methane venting between $12^{\circ} \mathrm{N}$ and $26^{\circ} \mathrm{N}$ along the Mid-Atlantic Ridge: Journal of Geophysical Research, v. 98, p. 9625-9642.

Charlou, J.L., Fouquet, Y., Donval, J.-P. and Auzende, J.M., 1996a, Mineral and gas chemistry of hydrothermal fluids on an ultrafast spreading ridge: East $\mathrm{Pa}$ cific Rise, $17^{\circ}$ to $19^{\circ} \mathrm{S}$, phase separation processes controlled by vbolcanic and tectonic activity: Journal of Geophysical Research, v. 101, p. 15,899-15,919

Charlou, J.L., Donval, J.P., Jean-Baptiste, P., Dapoigny, A., and Rona, P.A., 1996b, Gases and helium isotopes in high temperature solutions sampled before and after the ODP Leg 158 drilling at TAG hydrothermal field (26으, MAR): Geophysical Research Letters, v. 23, p. 3,491-3,494.

Charlou, J.L., Donval. J.P., Douville, E., Jean-Baptiste, P., Knoery, P., Fouquet, Y., Dapoigny, A., and Stievenard, M., 2000, Compared geochemical signature and evolution of Menez Gwen $\left(37^{\circ} 50^{\prime} \mathrm{N}\right)$ and Lucky Strike $\left(37^{\circ} 17^{\prime} \mathrm{N}\right)$ hydrothermal fluids, south of the Azores Triple Junction on the Mid-Atlantic Ridge: Chemical Geology, v. 171, p. 49-75.

Charlou, J.L., Donval, J.P., Fouquet, Y., Jean-Baptiste, P., and Holm, N., 2002, Geochemistry of high $\mathrm{H}_{2}$ and $\mathrm{CH}_{4}$ vent fluids issuing from ultramafic rocks at the Rainbow hydrothermal field $\left(36^{\circ} 14\right.$ 'N, MAR): Chemical Geology, v. 191, p. 345-359.

Cheminée, J.L., Stoffers, P., McMurtry, G., Richnow, H., Puteanus, D., and Sedwick, P., 1991, Gas-rich submarine exhalations during the 1989 eruption of Macdonald Seamount: Earth and Planetary Science Letters, v. 107, p. 318-327.

Chiba, H., Nakashima, K., Gamo, T., Ishibashi, J.-I., Tsunogai, U., and Sakai, H., 1993, Hydrothermal activity at the Minami-Ensei knoll, Okinawa trough: Chemical characteristics of hydrothermal solutions: Deep Sea Research, v. 9, p. 271-282.

Chiba, H., Ishibashi, J.-I., Ueno, H., Oomori, T., Uchiyama, N., Takeda, T., Takemine, C., Ri, J., and Itomitsu, A., 1996, Seafloor hydrothermal systems at North knoll, Iheya Ridge, Okinawa trough: Deep Sea Research, v. 12, p. 211-219.

Chiba, H., Masuda, H., Lee, S.-Y., and Fujioka, K., 2001, Chemistry of hydrothermal fluids at the TAG active mound, MAR $26^{\circ} \mathrm{N}$, in 1998: Geophysical Research Letters, v. 28, p. 2,919-2,922.

Dannielsson, L.-G., Dyrsson, D., and Graneli, A., 1980, Chemical investigations of Atlantis II and Discovery brines in the Red Sea: Geochimica et Cosmochimica Acta, v. 44, p. 2051-2065. 
de Ronde, C.E.J., 1995, Fluid chemistry and isotopic characteristics of seafloor hydrothermal systems and associated VMS deposits: Potential for magmatic contributions: Mineralogical Association of Canada Short Course Series 23, p. 479-509.

Douville, E., Bienvenu, P., Charlou, J.L., Donval, J.P., Fouquet, Y., Appriou, P., and Gamo, T., 1999, Yttrium and rare earth elements in fluids from various deep-sea hydrothermal systems: Geochimica et Cosmochimica Acta, v. 63, p. 627-643.

Douville, E., Charlou, J.L., Oelkers, E.H., Bienvenu, P., Jove Colon, C.F. Donval, J.P., Fouquet, Y., Prieur, D., and Appriou, P., 2002, Trace metals in hot acidic fluids from a deep-sea hydrothermal system in an ultramafic environment: Rainbow vent field ( $36^{\circ} 14^{\prime} \mathrm{N}$ MAR): Chemical Geology, v. 184, p. $37-48$.

Edmond, J.M., Campbell, A.C., Palmer, M.R., Klinkhammer, G.P., German, C.R., Edmonds, H.N., Elderfield, H., Thompson, G., and Rona, P., 1995, Time series studies of vent fluids from TAG and MARK sites $(1986,1990)$ Mid-Atlantic Ridge: A new solution chemistry model and a mechanism for $\mathrm{Cu} / \mathrm{Zn}$ zonation in massive sulphide orebodies: Geological Society of London Special Publication 87, p. 77-86.

Evans, S.C., White, L.D., and Rapp, J.B., 1988, Geochemistry of some gases in some hydrothermal fluids from the Juan de Fuca Ridge: Journal of Geophysical Research, v. 93, p. 15,305-15,313.

Fouquet, Y., von Stackelberg, U., Charlou, J.-L., Erzinger, J., Herzig, P.M., Muhe, R., and Wiedicke, M., 1993, Metallogenesis in back-arc environments: The Lau Basin example: Economic GEOLOGY, v. 88, p. 2154-2181.

Früh-Green, G.L., Kelley, D.S., Bernasconi, S.M., Karson, J., Ludwig, K.A., Butterfield, D.A., Boschi, C., and Proskurowski, G., 2003, 30,000 years of hydrothermal activity at the Lost City vent field: Science, v. 301, p. 495-498.

Gamo, T., 1995, Wide variation of chemical characteristics of submarine hydrothermal fluids due to secondary modification after high-temperature water-rock interaction: A review, in Sakai, H., and Nozaki, Y., eds., Biogeochemical processes and ocean flux in the Western Pacific: Tokyo, Terra Scientific Publishing, p. 425-451.

Gamo, T., Chiba, H., Masuda, H., Edmonds, H.N., Fujioka, K., Kodama, Y., Nanba, H., and Sano, Y., 1996, Chemical characteristeics of hydrothermal fluids from the TAG mound of the mid-Atlantic Ridge in August 1994: Implications for spatial and temporal variability of hydrothermal activity: Geophysical Research Letters, v. 23, p. 3483-3486.

Gamo, T., Okamura, K., Charlou, J.-L., Urabe, T., Auzende, J.-M., Ishibashi, J., Shitashima, K., Chiba, H., and Shipboard Scientific Party, 1997, Acidic and sulfate-rich hydrothermal fluids from the Manus back-arc basin, Papua New Guinea: Geology, v. 25, p. 139-142.

Gamo, T., Chiba, H., Yamanaka, T., Okudaira, T., Hashimoto, J., Tsuchida, S., Ishibashi, J., Kataoka, S., Tsunogai, U., Okamura, K., Sano, Y. and Shinjo, R., 2001, Chemical characteristics of newly discovered black smoker fluids and associated hydrothermal plumes at the Rodriguez Triple Junction, Central Indian Ridge: Earth and Planetary Science Letters, v. 193, p. 371-379.

German, C.R., and Von Damm, K.L., 2004, Hydrothermal processes: Treatise on Geochemistry, v. 6, p. 181-222.

Grimaud, D., Ishibashi, J., Lagabrielle, Y., Auzende, J-M., and Urabe, T., 1991, Chemistry of hydrothermal fluids from the $17^{\circ} \mathrm{S}$ active site on the North Fiji basin ridge (SW Pacific): Chemical Geology, v. 93, p. 209-218.

Hartmann, M., 1985, Atlantis II Deep geothermal brine system: Chemical processes between hydrothermal brines and Red Sea deep water: Marine Geology, v. 64, p. $157-177$.

Ishibashi, J., and Urabe, T., 1995, Hydrothermal activity related to arcbackarc magmatism in the Western Pacific, in Taylor, B., ed., Backarc basins: Tectonics and magmatism: New York, Plenum Press, p. 451-495.

Ishibashi, J., Tsunogai, U., Wakita, H., Watanabe, K., Kajimura, T., Shibata, A., Fujiwara, Y., and Hashimoto, J., 1994a, Chemical composition of hydrothermal fluids from Suiyo and Mokuyo Seamounts, Izu-Bonin arc: Deep Sea Research, v. 10, p. 89-97.

Ishibashi, J., Grimaud, D., Nojiri, Y., Auzende, J-M. and Urabe, T., 1994b, Fluctuation of chemical compositions of the phase-separated hydrothermal fluid from the North Fiji basin ridge: Marine Geology, v. 116, p. 215-226.

Ishibashi, J., Wakita, H., Nojiri, Y., Grimaud, D., Jean-Baptiste, P., Gamo, T., Auzende, J.-M., and Urabe, T., 1994c, Helium and carbon geochemistry of hydrothermal fluids from the North Fiji basin spreading ridge (southwest Pacific): Earth and Planetary Science Letters, v. 128, p. 183-197.

James, R.H., and Elderfield, H., 1996, Chemistry of ore-forming fluids and mineral formation rates in an active hydrothermal sulfide deposit on the Mid-Atlantic Ridge: Geology, v. 24, p. 1147-1150
Kelley, D.S., Karson, J.A., Blackman, D.K., Früh-Green, G.L., Butterfield, D.A., Lilley, M.D., Olson, E.J., Schrenk, M.O., Roe, K.K., Lebon, G.T., Rivizzigno, P. and the AT3-60 Shipboard Party, 2001, An off-axis hydrothermal vent field near the Mid-Atlantic Ridge at $30^{\circ} \mathrm{N}$ : Nature v. 412 , p. $145-149$.

Lilley, M.D., Baross, J.A., and Gordon, L.I., 1983, Reduced gases and bacteria in hydrothermal fluids: The Galapagos spreading center and $21^{\circ} \mathrm{N}$ East Pacific Rise: Marine Sciences, v. 12, p. 411-449.

Lilley, M.D., Butterfield, D.A., Olson, E.J., Lupton, J.E., Macko, S.A., and McDuff, R.E., 1993, Anomalous $\mathrm{CH}_{4}$ and $\mathrm{NH}_{4}{ }^{+}$concentrations at an unsedimented mid-ocean ridge hydrothermal system: Nature, v. 364, p 45-47.

Lupton, J.E., Baker, E.T., and Massoth, G.J., 1989, Variable ${ }^{3} \mathrm{He} /$ heat ratios in submarine hydrothermal systems: Evidence from two plumes over the Juan de Fuca ridge: Nature, v. 337, p. 161-164.

McMurtry, G.M., Sedwick, P.N., Fryer, P., VonderHaar, D.L., and Yeh, H.W., 1993, Unusual geochemistry of hydrothermal vents on submarine arc volcanoes: Kasuga Seamounts, northern Mariana arc: Earth and Planetary Science Letters, v. 114, p. 517-528.

Merlivat, L., Pineau, F., and Javoy, M., 1987, Hydrothermal vent waters at $13^{\circ} \mathrm{N}$ on the East Pacific Rise: Isotopic composition and gas concentration: Earth and Planetary Science Letters, v. 84, p. 100-108.

Rudnicki, M.D., and Elderfield, H., 1992, Helium, radon and manganese at the TAG and Snakepit hydrothermal vent fields, $26^{\circ}$ and $23^{\circ} \mathrm{N}$, Mid-Atlantic Ridge: Earth and Planetary Science Letters, v. 113, p. 307-321.

Sakai, H., Gamo, T., Kim, E-S., Shitsashima, K., Yanagisawa, F., Tsutsumi, M., Ishibashi, J., Tanaka, T., Sano, Y., Wakita, H., Tanak, T., Matsumoto, T., Naganuma, T., and Mitzuzawa, K., 1990a, Unique chemistry of hydrothermal solution in the mid-Okinawa backarc basin: Geophysical Research Letters, v. 17, p. 2133-2136.

Sakai, H., Gamo, T., Kim, E-S., Tsutsumi, M., Tanaka, T., Ishibashi, J. Wakita, H., Yamano, M., and Oomori, T., 1990b, Venting of carbon dioxiderich fluid and hydrate formation in mid-Okinawa trough backarc basin: Science, v. 248, p. 1093-1096.

Sedwick, P.N., McMurtry, G.M., and MacDougal, J.D., 1992, Chemistry of hydrothermal solutions from Pele's vents, Loihi seamount, Hawaii: Geochimica et Cosmochimica Acta, v. 56, p. 3643-3667.

Seyfried, W.E., Jr., Seewald, J.S., Berndt, M.E., Ding, K., and Foustoukos, D.I., 2003, Chemistry of hydrothermal vent fluids from the Main Endeavour field, northern Juan de Fuca Ridge: Geochemical controls in the aftermath of June 1999 seismic events: Journal of Geophysical Research, v. 108, 2429, 16 September, DOI10.1029/2002JB001957, 23 p.

Shanks, W.C., III, and Bischoff, J.L., 1980, Geochemistry, sulfur isotope composition, and accumulation rates of Red Sea geothermal deposits: ECONOMIC GEOLOGY, v. 75, p. 445-459.

Tsunogai, U., Ishibashi, J., Wakita, H., Gamo, T., Watanabe, K., Kajimura, T. Kanavama, S., and Sakai, H., 1994, Peculiar features of Suivo Seamount hydrothermal fluids, Izu-Bonin arc: Differences from subaerial volcanism: Earth and Planetary Science Letters, v. 126, p. 289-301.

Von Damm, K.L., 1990, Seafloor hydrothermal activity: Black smoker chemistry and chimneys: Annual Review of Earth and Planetary Sciences, v. 18, p. 173-204.

1995, Controls on the chemistry and temporal variability of seafloor hydrothermal fluids: Geophysical Monograph 91, p. 222-247.

Von Damm, K.L., Edmond, J.M., Grant, B., and Measures, C.I., 1985a, Chemistry of submarine hydrothermal solutions at $21^{\circ} \mathrm{N}$, East Pacific Rise: Geochimica et Cosmochimica Acta, v. 49, p. 2197-2220.

Von Damm, K.L., Edmond, J.M., Measures, C.I., and Grant, B., 1985b, Chemistry of submarine hydrothermal solutions at Guaymas basin, Gulf of California: Geochimica et Cosmochimica Acta, v. 49, p. 2221-2237.

Von Damm, K.L., Buttermore, L.G., Oosting, S.E., Bray, A.M., Fornari, D.J., Lilley, M.D., and Shanks, W.C., III, 1997, Direct observation of the evolution of a seafloor "black smoker" from vapor to brine: Earth and Planetary Science Letters, v. 149, p. 101-111.

Von Damm, K.L., Bray, A.M., Buttermore, L.G., and Oosting, S.E., 1998 , The geochemical controls on vent fluids from the Lucky Strike vent field, Mid-Atlantic Ridge: Earth and Planetary Science Letters, v. 160, p $521-536$

Von Damm, K.L., Lilley, M.D., Shanks, W.C. III., Brockington, M., Bray, A.M., O'Grady, K.M., Olson, E., Graham, A., Proskurowski, G., and Shipboard Science Party, 2003, Extraordinary phase separation and segregation in vent fluids from the southern East Pacific Rise: Earth and Planetary Science Letters, v. 206, p. 365-378. 
TABLE A4. Representative Isotopic Data for Hydrothermal Fluids from Selected Sea-Floor Vents

\begin{tabular}{|c|c|c|c|c|c|c|c|c|c|c|}
\hline $\begin{array}{l}\text { Tectonic setting } \\
\text { Location/vent }\end{array}$ & $\mathrm{T}_{\max }\left({ }^{\circ} \mathrm{C}\right)$ & $\mathrm{pH}\left(25^{\circ} \mathrm{C}\right)$ & $\mathrm{Cl}(\mathrm{mM})$ & $\begin{array}{l}\delta \mathrm{D}^{1} \\
(\% 0)\end{array}$ & $\begin{array}{c}\delta^{18} \mathrm{O}^{1} \\
(\% 0)\end{array}$ & $\begin{array}{c}\delta^{13} \mathrm{C}_{\mathrm{CO}_{2}} \\
(\% 0)\end{array}$ & $\begin{array}{c}\delta^{13} \mathrm{C}_{\mathrm{CH}_{4}} \\
(\% 0)\end{array}$ & $\begin{array}{c}\delta^{34} \mathrm{~S}_{\mathrm{H}_{2} \mathrm{~S}} \\
(\% \mathrm{o})\end{array}$ & $\begin{array}{c}{ }^{3} \mathrm{He} /{ }^{4} \mathrm{He} \\
\left(\mathrm{R} / \mathrm{R}_{\mathrm{A}}\right)\end{array}$ & ${ }^{87} \mathrm{Sr} / 86 \mathrm{Sr}$ \\
\hline \multicolumn{11}{|c|}{$\begin{array}{l}\text { Mid-ocean ridges: } \\
\text { Endeavour Ridge (1) }\end{array}$} \\
\hline Hulk & 353 & 4.5 & 505 & 1.1 & 0.8 & - & -55 to & 5.0 & 7.9 & - \\
\hline Dante & 370 & 4.4 & 457 & 1.7 & 0.9 & - & -48.4 & 4.3 & 7.9 & - \\
\hline S\&M & - & - & 334 & 1.6 & 1.0 & - & - & 4.6 & 7.9 & - \\
\hline Peanut & 350 & - & 253 & 1.5 & 0.9 & - & - & 3.8 & 7.9 & - \\
\hline Vent 1 & 285 & 3.2 & 896 & 0.5 & 0.7 & -3.8 & -17.8 & 6.4 & 7.7 & 0.7034 \\
\hline \multicolumn{11}{|l|}{$\begin{array}{l}\text { East Pacific Rise } \\
21^{\circ} \mathrm{N}, \mathrm{EPR}(4)\end{array}$} \\
\hline NGS & 273 & 3.8 & 579 & 2.0 & 1.5 & -7.0 & -15.0 & 3.4 & 7.8 & 0.7030 \\
\hline OBS & 350 & 3.4 & 489 & 2.8 & 1.5 & -7.0 & -17.4 & 1.4 & 7.8 & 0.7031 \\
\hline \multicolumn{11}{|l|}{$13^{\circ} \mathrm{N}, \operatorname{EPR}(5)$} \\
\hline Vent 3 & 380 & 3.3 & 760 & - & - & - & - & 3.5 & - & - \\
\hline Area A & 403 & - & 38 & -0.4 & 2.1 & - & - & 3.2 & - & - \\
\hline Area $\mathrm{C}$ & 326 & - & 329 & 1.5 & 0.6 & - & - & 3.9 & - & - \\
\hline Area $\mathrm{E}$ & 274 & - & 842 & 1.1 & 0.9 & - & - & 4.0 & - & - \\
\hline Area $\mathrm{F}$ & 386 & - & 45 & 1.4 & 1.5 & - & - & 6.4 & - & - \\
\hline Area G & 325 & - & 149 & -2.2 & 0.8 & - & - & 6.8 & - & - \\
\hline $\mathrm{F}$ vent '91 & 388 & 2.8 & 47 & 1.4 & 1.5 & - & - & - & - & - \\
\hline \multirow{2}{*}{\multicolumn{11}{|c|}{$17^{\circ} \mathrm{S}$, SEPR (8) }} \\
\hline & & & & & & & & & & \\
\hline $\begin{array}{l}\text { Nadir } \\
18^{\circ} \text { S SEPB (9) }\end{array}$ & \multirow{2}{*}{\multicolumn{7}{|c|}{$18^{\circ} \mathrm{S}, \mathrm{SEPR}(9)$}} & - & - & - \\
\hline $\begin{array}{l}\text { Akorta } \\
\text { Akn (y) }\end{array}$ & $>305$ & 3.3 & 848 & & - & -79 & -220 & & & \\
\hline Fromveur & 310 & 3.0 & $\begin{array}{l}040 \\
155\end{array}$ & - & - & $\begin{array}{l}-1.9 \\
-5.8\end{array}$ & $\begin{array}{l}-22.0 \\
-23.5\end{array}$ & - & 一 & - \\
\hline \multicolumn{11}{|l|}{$21^{\circ} \mathrm{S}, \mathrm{SEPR}(10)$} \\
\hline Karei 2 & 360 & 3.4 & 645 & 1.2 & 1.6 & -6.1 & -8.7 & 7.0 & 7.9 & 0.7042 \\
\hline \multicolumn{11}{|c|}{ Ridge-hot spot intersections: } \\
\hline Inferno & 328 & 3.5 & 624 & 2.5 & 1.1 & - & - & 6.1 & 8.1 & - \\
\hline Virgin & 299 & 4.4 & 176 & 2.6 & 0.9 & - & - & 7.3 & 8.1 & - \\
\hline Lucky Strike (16) & & & & & & & & & & \\
\hline Eiffel & 325 & 4.1 & 438 & - & - & -7.2 to & -12.7 to & - & - & - \\
\hline Crystal & 281 & 4.2 & 535 & - & - & -10.6 & -13.7 & - & - & - \\
\hline Menez Gwen (17) & 284 & 4.2 & 380 & - & - & -6.8 to -9.1 & -18.8 to -19.6 & - & - & - \\
\hline Ultramafic hosted: & & & & & & & & & & \\
\hline Rainbow (18) & 364 & 2.8 & 750 & - & - & -3.1 to 1.0 & -18.2 to -13 & - & - & - \\
\hline Logatchev (19) & 353 & 3.3 & 515 & - & - & -4.3 & -13.6 & - & - & - \\
\hline Lost City (20) & $<75$ & $9-9.8$ & 549 & - & 0.1 & $(1.4 \text { to } 2.4)^{3}$ & - & - & - & 0.7072 \\
\hline $\begin{array}{l}\text { Sedimented ridges } \\
\text { Guaymas basin }(21\end{array}$ & & & & & & & & & & \\
\hline Area 2 & 291 & 5.9 & 589 & - & - & -6 to 2.7 & -43 to -51 & - & - & 0.7052 to \\
\hline Area 3 & 285 & 5.9 & 637 & - & - & - & - & - & - & 0.7059 \\
\hline Middle Valley (22) & & & & & & & & & & \\
\hline Dead Dog & 276 & 5.5 & 578 & - & - & - & - & - & - & 0.7042 to \\
\hline Bent Hill & 265 & 5.1 & 412 & - & - & - & - & - & - & 0.7044 \\
\hline Escanaba (23) & 217 & 5.4 & 668 & - & - & - & - & - & - & 0.7099 \\
\hline Red Sea, AII (24) & 66 & 5.5 & 4406 & 5.6 & 0.7 & - & - & $(5.4)^{4}$ & 12.7 & 0.7071 \\
\hline
\end{tabular}


TABLE A4. (Cont.)

\begin{tabular}{|c|c|c|c|c|c|c|c|c|c|c|}
\hline $\begin{array}{l}\text { Tectonic setting } \\
\text { Location/vent }\end{array}$ & $\mathrm{T}_{\max }\left({ }^{\circ} \mathrm{C}\right)$ & $\mathrm{pH}\left(25^{\circ} \mathrm{C}\right)$ & $\mathrm{Cl}(\mathrm{mM})$ & $\begin{array}{l}\delta \mathrm{D}^{1} \\
(\% o)\end{array}$ & $\begin{array}{c}\delta^{18} \mathrm{O}^{1} \\
(\% 0)\end{array}$ & $\begin{array}{c}\delta^{13} \mathrm{C}_{\mathrm{CO}_{2}} \\
(\% 0) \\
\end{array}$ & $\begin{array}{c}\delta^{13} \mathrm{C}_{\mathrm{CH}_{4}} \\
(\% 0) \\
\end{array}$ & $\begin{array}{c}\delta^{34} \mathrm{~S}_{\mathrm{H}_{2} \mathrm{~S}} \\
(\% \circ)\end{array}$ & $\begin{array}{c}{ }^{3} \mathrm{He} / 4 \mathrm{He} \\
\left(\mathrm{R} / \mathrm{R}_{\mathrm{A}}\right)\end{array}$ & ${ }^{87} \mathrm{Sr} /{ }^{66} \mathrm{Sr}$ \\
\hline \multicolumn{11}{|c|}{$\begin{array}{l}\text { Intraoceanic back-arc basins: } \\
\text { North Fiji basin }(25)\end{array}$} \\
\hline White Lady & 285 & 4.7 & 255 & - & - & -6.2 & -18.9 & - & 9.9 & 0.7046 \\
\hline Kaiyo/LHOS & 291 & 4.7 & 267 & - & - & -5.7 & -19.8 & - & 9.0 & 0.7046 \\
\hline \multicolumn{11}{|l|}{ Lau basin (26) } \\
\hline Vai Lili-1 & 280 & - & 712 & - & - & - & - & - & - & 0.7044 \\
\hline Vai Lili-3 & 334 & 2.0 & 790 & - & - & - & - & - & - & 0.7044 \\
\hline \multicolumn{11}{|c|}{ Mariana trough (27) } \\
\hline Alice Springs & 285 & 4.4 & 544 & - & - & -4.3 & - & 3.6 to 4.8 & 8.5 & 0.7037 \\
\hline \multicolumn{11}{|l|}{ Volcanic arcs: } \\
\hline \multicolumn{11}{|l|}{ Izu-Bonin-Mariana } \\
\hline Suiyo Smt. (28) & 311 & 3.7 & 658 & - & - & -2.7 to -1.0 & -8.5 & - & 8.2 & - \\
\hline Kasuga Smt. (29) & 39 & 5.2 & 515 & - & - & - & - & - & - & 0.7080 \\
\hline \multicolumn{11}{|c|}{$\begin{array}{l}\text { Transitional arcs and back-arc basins: } \\
\text { Manus Basin (30) }\end{array}$} \\
\hline DESMOS & 88 & 2.2 & 495 & -8.1 & 0.3 & - & - & -5.7 & - & - \\
\hline \multicolumn{11}{|c|}{ Okinawa Trough (31) } \\
\hline JADE & 320 & 4.7 & 550 & - & - & -5.0 to -4.7 & -36 to -41 & 7.4 to 7.7 & 6.1 to 6.9 & 0.7089 \\
\hline Minami-Ensei & 278 & 5.0 & 527 & - & - & -4.0 to -5.3 & -29.5 & 3.6 & 7.0 to 7.5 & 0.7100 \\
\hline \multicolumn{11}{|c|}{ Intraplate hot-spot volcanoes: } \\
\hline Loihi (32) & 31 & 5.6 & 522 & - & - & - & - & - & 23.9 & 0.7092 \\
\hline Macdonald (33) & - & - & 491 & - & - & - & - & - & 7.4 & - \\
\hline Seawater & 2 & 7.8 & 541 & 0.0 & 0.0 & -5.1 to -5.9 & - & - & 1.0 & 0.7090 \\
\hline
\end{tabular}

Sources: Representative data from compilations by Von Damm (1990), de Ronde (1995), Gamo (1995), Von Damm (1995), Butterfield (2000), and German and Von Damm (2004), with additional data according to the references cited in Table A3

Notes: $\mathrm{Cl}$ concentrations are reported in $\mathrm{mM} \mathrm{kg}^{-1} ; \delta \mathrm{D}$ and $\delta^{18} \mathrm{O}$ values are reported with respect to SMOW; $\delta^{13} \mathrm{C}$ to $\mathrm{PDB} ; \delta^{34} \mathrm{~S}$ to $\mathrm{CDT} ; \mathrm{R} / \mathrm{R}_{\mathrm{A}}, \mathrm{R}=$ ${ }^{3} \mathrm{He} /{ }^{4} \mathrm{He}$ and $\mathrm{R}_{\mathrm{A}}=\left({ }^{3} \mathrm{He} /{ }^{4} \mathrm{He}\right)_{\text {Air }}$ which is $1.4 \times 10^{-6} ;-=$ data not available

${ }^{1}$ End-member hydrothermal fluid values calculated after correcting for entrainment of local bottom water

${ }^{2}$ Data listed are values within the reported range that deviate most from seawater

${ }^{3}$ Carbonate carbon isotope values reported for aragonite from active vents

${ }^{4}$ Average sulfide sulfur isotope value reported for sulfides deposited from lower brine 
TABLE A5. Sources of Sulfur Isotope Data on Sea-Floor Polymetallic Sulfides Shown in Figure 7 of Hannington et al. (2005)

\begin{tabular}{|c|c|c|c|c|}
\hline Location & Average $\delta^{34} \mathrm{~S}(\% \circ)$ & Minimum & Maximum & Number of Analyses \\
\hline Central Indian Ridge (Sonne field) & 3.4 & 1.6 & 6.6 & 54 \\
\hline Axial Seamount & 4.2 & 1.1 & 9.4 & 113 \\
\hline Galapagos rift & 4.4 & 2.7 & 6.4 & 29 \\
\hline Southern Juan de Fuca Ridge (SJFR) & 3.2 & 1.6 & 5.7 & 44 \\
\hline $11^{\circ} \mathrm{N}$ East Pacific Rise & 3.5 & 1.2 & 4.9 & 51 \\
\hline $13^{\circ} \mathrm{N}$ East Pacific Rise & 2.6 & 0.3 & 5.8 & 112 \\
\hline $21^{\circ} \mathrm{N}$ East Pacific Rise & 2.5 & 0.7 & 6.2 & 162 \\
\hline Southern East Pacific Rise & 3.8 & 0.9 & 8.9 & 137 \\
\hline Snakepit, Mid-Atlantic Ridge & 2.1 & 1.2 & 2.8 & 16 \\
\hline Broken Spur, Mid-Atlantic Ridge & 1.3 & -0.8 & 3.2 & 48 \\
\hline Logatchev, Mid-Atlantic Ridge & 7.6 & 0.7 & 13.8 & 26 \\
\hline Rainbow, Mid-Atlantic Ridge & 8.8 & 0.5 & 12.5 & 54 \\
\hline TAG mound, Mid-Atlantic Ridge & 6.8 & 0.4 & 10.3 & 269 \\
\hline Grimsey graben, Iceland & -7.6 & -16.8 & -0.4 & 15 \\
\hline Guaymas basin & -0.4 & -9.7 & 11.1 & 91 \\
\hline Middle Valley & 6.2 & -8.0 & 17.6 & 174 \\
\hline Atlantis II Deep, Red Sea & 0.9 & -33.8 & 14.3 & 75 \\
\hline Kebrit and Shaban Deeps & 3.9 & -16.2 & 13.6 & 49 \\
\hline Escanaba trough & 5.0 & -0.1 & 11.6 & 71 \\
\hline Vai Lili Field, Lau basin & 8.8 & 6.9 & 16.2 & 22 \\
\hline Northern Lau basin & 8.6 & 6.1 & 9.8 & 13 \\
\hline JADE Field, Okinawa trough & 6.9 & 3.2 & 11.2 & 24 \\
\hline White Church, Lau basin & 4.2 & 2.2 & 7.1 & 22 \\
\hline Manus basin & 2.6 & -1.9 & 6.0 & 53 \\
\hline Mariana trough & 3.3 & 0.7 & 8.1 & 22 \\
\hline Myojinsho caldera & 1.0 & -5.3 & 2.8 & 6 \\
\hline Brothers Seamount, Kermadec arc & -2.3 & -8.3 & 3.0 & 19 \\
\hline DESMOS cauldron, Manus basin & $\mathrm{Na}$ & -7.3 & -5.7 & 9 \\
\hline Hine Hina field, Lau basin & -4.7 & -7.7 & -2.4 & 16 \\
\hline Conical Seamount & -3.2 & -13.9 & 2.0 & 28 \\
\hline
\end{tabular}

Sources of data: Central Indian Ridge (Halbach and Munch, 2000); Axial Seamount (Hannington and Scott, 1988; Crowe and Valley, 1992); Galapagos rift (Skirrow and Coleman, 1982; Knott et al., 1995); southern Juan de Fuca Ridge (SJFR; Shanks and Seyfried, 1987); $11^{\circ} \mathrm{N} \mathrm{EPR} \mathrm{(Bluth} \mathrm{and} \mathrm{Ohmoto,} \mathrm{1988;} \mathrm{Mc-}$ Conachy, 1988); 13N, EPR (Bluth and Ohmoto, 1988; Stuart et al., 1995; Fouquet et al., 1996); $21^{\circ} \mathrm{N}$ EPR (Hekinian et al., 1980; Arnold and Sheppard, 1981; Styrt et al., 1981; Kerridge et al., 1983; Zierenberg et al., 1984; Woodruff et al., 1988; Stuart et al., 1994a); southern EPR (Marchig et al., 1990, 1997); Snakepit (Kase et al., 1990); Broken Spur (Duckworth et al., 1995; Butler et al., 1998); Rainbow (Lein et al., 2003); Logatchev (Bogdanov et al., 1997); TAG mound (Lein et al., 1991; Stuart et al., 1994a; Chiba et al., 1998; Gemmell and Sharpe, 1998; Herzig et al., 1998a; Knott et al., 1998; Petersen et al., 2000); Grimsey Graben (S. Petersen and T. Khun, unpub. data); Guaymas basin (Shanks and Niemitz, 1982; Koski et al., 1985; Peter and Shanks, 1992); Middle Valley (Goodfellow and Blaise, 1988; Duckworth et al., 1994; Stuart et al., 1994b; Zierenberg, 1994); Atlantis II Deep, Red Sea (Kaplan et al., 1969; Shanks and Bischoff, 1980; Zierenberg and Shanks, 1988); Kebrit and Shaban Deeps, Red Sea (Blum and Puchelt, 1991); Escanaba trough (Koski et al., 1988; Zierenberg et al., 1993; Böhlke and Shanks, 1994; Zierenberg and Shanks, 1994); Vai Lili field, Lau basin (Herzig et al., 1998b; U. Schwarz-Schampera, unpub. data); northern Lau basin (Bortnikov et al., 1993), Okinawa trough, JADE site (Halbach et al., 1989; Marumo and Hattori, 1999); White Church, Lau basin (Herzig et al., 1998b; U. Schwarz-Schampera, unpub. data); Manus basin (Lein et al., 1993; Huston et al., 1995); Mariana trough (Kusakabe et al., 1990; Maki and Mizota, 1997); Myojinsho caldera (Iizasa et al., 1992); Brothers Seamount (de Ronde et al., 2003; M. Hannington, unpub. data); Desmos caldera (Gemmell et al., 1999; Gamo et al., 1997; M. Hannington, unpub. data); Hine Hina field, Lau basin (Herzig et al., 1998b; U. Schwarz-Schampera, unpub. data); Conical Seamount (Petersen et al., 2002)

\section{REFERENCES}

Alt, J.C., 1988, The chemistry and sulfur isotope composition of massive sulfide and associated deposits on Green Seamount, Eastern Pacific: EcoNOMIC GEOLOGY, v. 83, p. 1026-1033.

Arnold, M., and Sheppard, S.M.F., 1981, East Pacific Rise at latitude $21^{\circ} \mathrm{N}$ : Isotopic composition and origin of the hydrothermal sulphur: Earth and Planetary Science Letters, v. 56, p. 148-156.

Bluth, G.J., and Ohmoto, H., 1988, Sulfide-sulfate chimneys on the East Pacific Rise, $11^{\circ}$ and $13^{\circ} \mathrm{N}$ latitude. Part II: Sulfur isotopes: Canadian Mineralogist, v. 26, p. 505-515.

Blum, N., and Puchelt, H., 1991, Sedimentary-hosted polymetallic massive sulfide deposits of the Kebrit and Shaban Deeps, Red Sea: Mineralium Deposita, v. 26, p. 217-227.

Böhlke, J.K., and Shanks, W.C., 1994, Stable isotope study of hydrothermal vents at Escanaba trough: Observed and calculated effects of sediment-seawater interaction: U.S. Geological Survey Bulletin, v. 2022, p. 223-239.

Bogdanov, Y.A., Bortnikov, N.S., Vikentyev, I.V., Gurvich, E.G., and Sagalevich, A.M., 1997, A new type of modern mineral-forming systems: Black smokers of the hydrothermal field at $14^{\circ} 45^{\prime} \mathrm{N}$ latitude, Mid-Atlantic Ridge: Geology of Ore Deposits, v. 39, p. 68-90.

Bortnikov, N.S., Fedorov, D.T., and Murav'ev, K.G., 1993, Mineral composition and conditions of the formation of sulfide edifices in the Lau basin (southwestern sector of the Pacific Ocean): Geology of Ore Deposits, v. 35, p. $476-488$.

Butler, I.B., Fallick, A.E., and Nesbitt, R.W., 1998, Mineralogy, sulphur isotope geochemistry and the development of sulphide structures at the Broken Spur hydrothermal vent site, $29^{\circ} 10^{\prime} \mathrm{N}$, Mid-Atlantic Ridge: Journal of the Geological Society of London, v. 155, p. 773-785.

Chiba, H., Uchiyama, N., and Teagle, D.A.H., 1998, Stable isotope study of anhydrite and sulfide minerals at the TAG hydrothermal mound, Mid-Atlantic Ridge, $26^{\circ} \mathrm{N}$ : Proceedings of the Ocean Drilling Program, Scientific Results, v. 158 , p. 85-90.

Crowe, D.E., and Valley, J.W., 1992, Laser microprobe study of sulphur isotope variation in a sea-floor hydrothermal spire, Axial Seamount, Juan de Fuca Ridge, eastern Pacific: Chemical Geology, v. 101, p. 63-70.

Davis, A.S., Clague, D.A., Zierenberg, R.A., Wheat, C.G., and Cousens, B.L., 2003, Sulfide formation related to changes in the hydrothermal system on 
Loihi Seamount, Hawai'i, following the seismic event in 1996: Canadian Mineralogist, v. 41, p. 457-472.

de Ronde, C., Faure, K., Bray, C.M., Chappell, D.A., and Wright, I.C., 2003, Hydrothermal fluids associated with seafloor mineralization at two southern Kermadec arc volcanoes, offshore New Zealand: Mineralium Deposita, v. 38 , p. $217-233$.

Duckworth, R.C., Fallick, A.E., and Rickard, D., 1994, Mineralogy and sulfur isotopic composition of the Middle Valley massive sulfide deposit, northern Juan de Fuca Ridge: Proceedings of the Ocean Drilling Program, Scientific Results, v.139, p. 373-385.

Duckworth, R.C., Knott, R., Fallick, A.E., Rickard, D., Murton, B.J., and van Dover, C., 1995, Mineralogy and sulphur isotope geochemistry of the Broken Spur sulphides, $29^{\circ} \mathrm{N}$, Mid-Atlantic Ridge: Geological Society of London Special Publication, v. 87, p. $175-189$

Fouquet, Y., Knott, R., Cambon, P., Fallick, A.E., Rickard, D., and Desbruyeres, D., 1996, Formation of large sulfide mineral deposits along fast spreading ridges: Examples from off-axial deposits at $12^{\circ} 43^{\prime} \mathrm{N}$ on the East Pacific Rise: Earth and Planetary Science Letters, v. 144, p. 147-162.

Gamo, T., Okamura, K., Charlou, J.-L., Urabe, T., Auzende, J.-M., Ishibashi, J., Shitashima, K., Chiba, H., and Shipboard Scientific Party, 1997, Acidic and sulfate-rich hydrothermal fluids from the Manus back-arc basin, Papua New Guinea: Geology, v. 25, p. 139-142.

Gemmell, J.B., and Sharpe, R., 1998, Detailed sulfur-isotope investigation of the TAG hydrothermal mound and stockwork zone: Proceedings of the Ocean Drilling Program, Scientific Results, v. 158, p. 71-84.

Gemmell, J.B., Binns, R.A., and Parr, J.M., 1999, Submarine, high sulfidation alteration within DESMOS caldera, Manus basin, PNG, in Stanley, C.J., ed., Mineral deposits: Processes to processing: Proceedings of the Fifth Biennial SGA Meeting and the Tenth Quadrennial IAGOD Symposium: Rotterdam, Brookfield, VT, Balkema, p. 503-506.

Goodfellow, W.D., and Blaise, B., 1988, Sulfide formation and hydrothermal alteration of hemipelagic sediment in Middle Valley, northern Juan de Fuca Ridge: Canadian Mineralogist, v. 26, p. 675-696.

Halbach, P., and Münch, U., 2000, Mineral deposits at $23^{\circ}$ S, Central Indian Ridge: Mineralogical features, chemical composition, and isotopic investigations, in Cronan, D. S., ed., Handbook of marine mineral deposits: Boca Rotan, FL, CRC Press, p. 327-346.

Halbach, P., Wahsner, M., Käselitz, L., Sakai, H., and Hein, U., 1989, The Jade hydrothermal field in the Okinawa trough-first discovery of massive sulphides in an intracontinental back-arc basin, in Miles, D.L., ed., Waterrock interaction: Rotterdam, Balkema, p. 279-283.

Hannington, M.D., and Scott, S.D., 1988, Mineralogy and geochemistry of an hydrothermal silica-sulfide-sulfate spire in the caldera of AxialSeamount, Juan de Fuca Ridge: Canadian Mineralogist, v. 26, p. 603-625.

Hekinian, R., Fevrier, M., Bischoff, J.L., Picot, P., and Shanks, W.C., 1980, Sulfide deposits from the East Pacific Rise near $21^{\circ}$ N: Science, v. 207, p. 1433-1444.

Herzig, P.M., Petersen, S., and Hannington, M.D., 1998a, Geochemistry and sulfur-isotopic composition of the TAG hydrothermal mound, Mid-Atlantic Ridge, $26^{\circ} \mathrm{N}$ : Proceedings of the Ocean Drilling Program, Scientific Results, v. 158 , p. $47-70$.

Herzig, P.M., Hannington, M.D., and Arribas, A., 1998b, Sulfur isotopic composition of hydrothermal precipitates from the Lau back-arc: Implications for magmatic contributions to seafloor hydrothermal systems: Mineralium Deposita, v. 33, p. 226-237.

Huston, D.L., Power, M., Gemmell, J.B., and Large, R.R., 1995, Design, calibration and geological application of the first operational Australian laser ablation sulphur isotope microprobe: Australian Journal of Earth Sciences, v. 42 , p. $549-555$

Iizasa, K., Yusa, M., and Yokota, S., 1992, Mineralogy and geochemistry of volcanogenic sulfides from the Myojinsho submarine caldera, the SichitoIwojima Ridge, Izu-Ogasawara arc, northwestern Pacific: Marine Geology, v. 108 , p. $39-58$

Janecky, D.R., and Shanks, W.C.I., 1988, Computational modeling of chemical and isotopic reaction processes in seafloor hydrothermal systems: Chimneys, massive sulfides, and subjacent alteration zones: Canadian Mineralogist, v. 26, p. 805-825.

Kaplan, I.R., Sweeney, R.E., and Nissenbaum, A., 1969, Sulfur isotope studies on Red Sea geothermal brines and sediments, in Degens, E.T., and Ross, D.A., ed., Hot brines and recent heavy metal deposits in the Red Sea: New York, Springer Verlag, p. 474-498.

Kase, K., Yamamoto, M., and Shibata, T., 1990, Copper-rich sulfide deposits near $23^{\circ} \mathrm{N}$, Mid-Atlantic Ridge: Chemical composition, mineral chemistry, and sulfur isotopes: Proceedings of the Ocean Drilling Program, Scientific Results, v. 106/109, p. 163-172.

Kerridge, J.F., Haymon, R.M., and Kastner, M., 1983, Sulfur isotope systematics at the $21^{\circ} \mathrm{N}$ site, East Pacific Rise: Earth and Planetary Science Letters, v. 66 , p. $91-100$.

Knott, R., Fallick, A.E., Rickard, D., and Bäcker, H., 1995, Mineralogy and sulphur isotope characteristics of a massive sulphide boulder, Galapagos Rift, 8555’W: Geological Society of London Special Publication, v. 87, p. $207-222$

Knott, R., Fouquet, Y., Honnorez, J., Petersen, S., and Bohn, M., 1998 Petrology of hydrothermal mineralization: A vertical section through the TAG mound: Proceedings of the Ocean Drilling Program, Scientific Results, v. 158 , p. 5-26.

Koski, R.A., Lonsdale, P.F., Shanks, W.C., Berndt, M.E., and Howe, S.S. 1985, Mineralogy and geochemistry of a sediment-hosted hydrothermal sulfide deposit from the southern trough of Guaymas basin, Gulf of California: Journal of Geophysical Research, v. 90, p. 6695-6707.

Koski, R.A., Shanks, W.C.I., Bohrson, W.A., and Oscarson, R.L., 1988, The composition of massive sulfide deposits from the sediment-covered floor of Escanaba trough, Gorda Ridge: Implications for depositional processes: Canadian Mineralogist, v. 26, p. 655-673.

Kusakabe, M., Mayeda, S., and Nakamura, E., 1990, S, O and Sr isotope systematics of active vent materials from the Mariana backarc basin spreading axis at $18^{\circ} \mathrm{N}$ : Earth and Planetary Science Letters, v. 100, p. 275-282.

Lein, A.Y., Ulyanova, N.V., Grinenko, V.A., and Lisitsyn, A.P., 1991, Geochemistry of the hydrothermal sulfide ores of the Mid-Atlantic ridge $\left(26^{\circ} \mathrm{N}\right)$ : Geochemistry International, v. 28, p. 1-13.

Lein, A.Y., Ulyanova, N.V., Grinenko, V.A., Bibikova, Y.V., and Lisitsyn, A.P., 1993. Mineralogical and geochemical features of the Manus basin hydrothermal sulfide ores, Bismarck Sea: Geochemistry International, v. 30 , p. $57-71$.

Lein, A.Y., Cherkashev, G.A., Ulyanov, A.A., Ulyanova, N.V., Stepanova, T.V., Sagalevich, A.M., Bogdanov, Y.A., Gurvich, E.G., and Torokhov, M.P., 2003, Mineralogy and geochemistry of sulfide ores from the Logatchev-2 and Rainbow fields: Similar and distinctive features: Geochemistry International, v. 41, p. 271-294.

Maki, Y., and Mizota, C., 1997, Sulfur isotopic composition of Alvinoconcha hessleri and Chorocaris vandoverae from Mariana back-arc basin: Jamstec Deepsea Research, v. 13, p. 63-67.

Marchig, V., Puchelt, H., Rösch, H., and Blum, N., 1990, Massive sulfides from ultra-fast spreading ridge, East Pacific Rise at $18-21^{\circ} \mathrm{S}$ : A geochemical stock report: Marine Mining, v. 9, p. 459-493.

Marchig, V., Blum, N., and Roonwal, G., 1997, Massive sulfide chimneys from the East Pacific Rise at $7^{\circ} 24^{\prime} \mathrm{S}$ and $16^{\circ} 43^{\prime} \mathrm{S}$ : Marine Georesources and Geotechnology, v. 15, p. 49-66.

Marumo, K., and Hattori, K.H., 1999, Seafloor hydrothermal clay alteration at Jade in the back-arc Okinawa Trough: Mineralogy, geochemistry and isotope characteristics: Geochimica et Cosmochimica Acta, v. 63, p. 2785-2804

McConachy, T.F., 1988, Hydrothermal plumes and related deposits over spreading ridges in the northeast Pacific Ocean: The East Pacific Rise near $11^{\circ} \mathrm{N}$ and $21^{\circ} \mathrm{N}$, Explorer Ridge, and the J. Tuzo Wilson Seamounts: Unpublished Ph.D. thesis, Toronto, ON, University of Toronto, $403 \mathrm{p}$.

Peter, J.M., and Shanks, W.C., 1992, Sulfur, carbon, and oxygen isotope variations in submarine hydrothermal deposits of Guaymas basin, Gulf of California, USA: Geochimica et Cosmochimica Acta, v. 56, p. 2025-2040.

Petersen, S., Herzig, P.M., and Hannington, M.D., 2000, Third dimension of a presently forming VMS deposit: TAG hydrothermal mound, Mid-Atlantic Ridge, $26^{\circ} \mathrm{N}$ : Mineralium Deposita, v. 35, p. 233-259.

Petersen, S., Herzig, P.M., Hannington, M.D., Jonasson, I.R., and Arribas, A.Jr., 2002, Submarine vein-type gold mineralization near Lihir island, New Ireland fore-arc, Papua New Guinea: Economic Geology, v. 97, p. $1795-1813$.

Shanks, W.C., and Bischoff, J.L., 1980, Geochemistry, sulfur isotope composition, and accumulation rates of red sea geothermal deposits: ECONOMIC Geology, v. 75, p. $445-459$.

Shanks, W.C.I., and Niemitz, J., 1982, Sulfur isotope studies of hydrothermal anhydrite and pyrite, Deep Sea Drilling Project Leg 64, Guaymas Basin, Gulf of California: Initial Reports of the Deep Sea Drilling Project, v. 64 p. $1137-1142$

Shanks, W.C.I., and Seyfried, W.E.j., 1987, Stable isotope studies of vent fluids and chimney minerals, southern Juan de Fuca Ridge. Sodium metasomatism and seawater sulfate reduction: Journal of Geophysical Research, v. 92 , p. 11,387-11,399. 
Skirrow, R., and Coleman, M.L., 1982, Origin of sulphur and geothermometry of hydrothermal sulphides from the Galapagos rift: Nature, v. 299, p. $142-144$.

Stuart, F.M., Turner, G., Duckworth, R.C., and Fallick, A.E., 1994a, Helium isotopes as tracers of trapped hydrothermal fluids in ocean-floor sulfides: Geology, v. 22, p. 823-826.

Stuart, F.M., Duckworth, R., Turner, G., and Schofield, P.F., 1994b, Helium and sulfur isotopes of sulfide minerals from Middle Valley, northern Juan de Fuca Ridge: Proceedings of the Ocean Drilling Program, Scientific Results, v. 139 , p. 387-392.

Stuart, F.M., Harrop, P.J., Knott, R., Fallick, A.E., Turner, G., Fouquet, Y., and Rickard, D., 1995, Noble gas isotopes in 25000 years of hydrothermal fluids from $13^{\circ} \mathrm{N}$ on the East Pacific Rise: Geological Society of London Special Publication, v. 87, p. 133-143.

Styrt, M.M., Brackmann, A.J., Holland, H.D., Clark, B.C., Pisutha-Arnond, V., Eldridge, C.S., and Ohmoto, H., 1981, The mineralogy and the isotopic composition of sulfur in hydrothermal sulfide/sulfate deposits on the East Pacific Rise, $21^{\circ} \mathrm{N}$ latitude: Earth and Planetary Science Letters, v. 53, p. 382-390.

Woodruff, L.G., and Shanks, W.C.I., 1988, Sulfur isotope study of chimney minerals and hydrothermal fluids from $21^{\circ} \mathrm{N}$, East Pacific Rise: Hydrothermal sulfur sources and disequilibrium sulfate reduction: Journal of Geophysical Research, v. 93, p. 4562-4572.
Zierenberg, R.A., 1994, Sulfur content of sedimentes and sulfur isotope values of sulfide and sulfate minerals from Middle Valley: Proceedings of the Ocean Drilling Program, Scientific Results, v. 139, p. 739-748.

Zierenberg, R.A., and Shanks, W.C., 1988, Isotopic studies of epigenetic features in metalliferous sediment, Atlantis II Deep, Red Sea: Canadian Mineralogist, v. 26, p. 737-753.

1994, Sediment alteration associated with massive sulfide formation in Escanaba trough, Gorda Ridge: The importance of seawater mixing and magnesium metasomatism: U.S. Geological Survey Bulletin 2022, p. $257-277$.

Zierenberg, R.A., Shanks, W.C.I., and Bischoff, J.L., 1984, Massive sulfide deposits at $21^{\circ}$, East Pacific Rise: Chemical composition, stable isotopes, and phase equilibria: Geological Society of America Bulletin, v. 95, p. 922-929.

Zierenberg, R.A., Koski, R.A., Morton, J.L., Bouse, R.M., and Shanks W.C.I., 1993, Genesis of massive sulfide deposits on a sediment-covered spreading center, Escanaba trough, southern Gorda Ridge: EconOmIC GEOLOGY, v. 88, p. 2069-2098. 